Portland State University

PDXScholar

1992

\title{
Hawthorne Boulevard: Commercial Gentrification and the Creation of an Image
}

Rachel Ann Hardyman

Portland State University

Follow this and additional works at: https://pdxscholar.library.pdx.edu/open_access_etds

Part of the Geography Commons, Urban Studies Commons, and the Urban Studies and Planning Commons

Let us know how access to this document benefits you.

\section{Recommended Citation}

Hardyman, Rachel Ann, "Hawthorne Boulevard: Commercial Gentrification and the Creation of an Image" (1992). Dissertations and Theses. Paper 4056.

https://doi.org/10.15760/etd.5940

This Thesis is brought to you for free and open access. It has been accepted for inclusion in Dissertations and Theses by an authorized administrator of PDXScholar. Please contact us if we can make this document more accessible: pdxscholar@pdx.edu. 
AN ABSTRACT OF THE THESIS OF Rachel Ann Hardyman for the Master of Science in Geography presented October 29, 1992.

Title: Hawthorne Boulevard: Commercial Gentrification and the Creation of an Image.

APPROVED BY THE MEMBERS OF THE THESIS COMMITTEE:

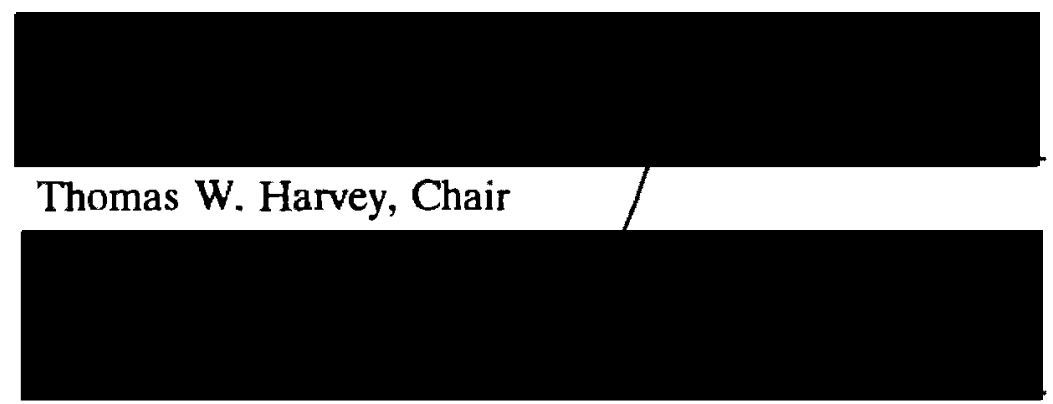

Martha A. Works

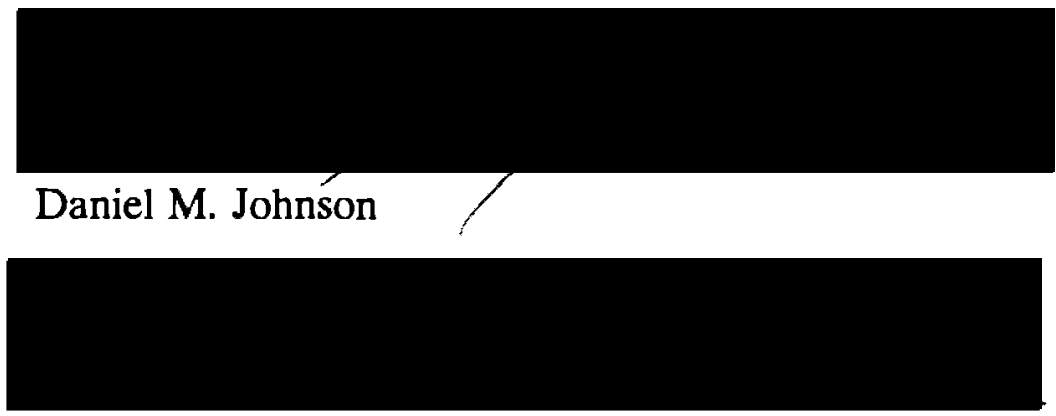

Carl J. Abbott

Portland's Southeast Hawthorne Boulevard illustrates commercial gentrification in progress. Once a declining service district, 'Hawthorne' is now one of the city's most popular shopping streets. Tracing and classifying businesses, using address listings from city directories, gives an accurate picture of changes 
since 1980. Three parallel trends can be distinguished in the makeup of the business mix: a shift from services to retailing; a move towards a regional, rather than a neighborhood, market area; and a cultural upgrading associated with the influx of increasingly expensive stores. Classification also aids in the definition of a tipping point at which revitalization became gentrification.

The actions of individual entrepreneurs in the revitalization process were complemented by the Hawthorne business association's participation in the Main Street program, a national project to improve declining retail districts. The program helped the Hawthorne district become more successful by encouraging physical improvements, special promotions and greater communication among merchants.

Hawthorne has experienced dramatic increases in the numbers of restaurants, gifts shops and clothing stores, and a decline in convenience and household goods. Its changing role and evolving image exemplify the national trend towards specialized, recreational retailing. The district has retained its longstanding reputation as a focus for used books and stereo equipment and, in spite of becoming a regional magnet, still reflects the character of its surrounding neighborhoods.

The commercial was accompanied by a shift in business orientation. The conspicuous consumption and high prices usually associated with gentrification are moderated by a large number of stores that advocate 'political correctness' and promote recycling. Hawthorne is typified by the presence of alternative 
subcultural groups such as bohemians and gays. The district's continued accessibility to poorer sectors of society is apparent in the large number of stores selling secondhand goods. Coincident with its bohemian image, many stores have a strong feminist slant. Hawthorne as a whole serves as a focus for Portland's lesbian community. Hawthorne's multi-faceted image is created by the stores and their advertising, and by planned ventures of the business association.

The well-educated, low-income, female-focused nature of many stores reflect the character of neighborhood while drawing like-minded people from all over the city. Hawthorne's neighborhoods have a lower rate of owner occupancy, more non-family households, and a higher percentage of women than the city as a whole. The five census tracts adjacent to Hawthorne have above average education levels but lower household incomes than the city median.

The significance of gentrification lies in it being a manifestation of broader changes affecting society as a whole. Changes in gender divisions, the break-down of the traditional household, the evolution of lifestyle-based neighborhoods, and the increasing appeal of diverse central city neighborhoods are all creating new places and new forms of consumption. The Hawthorne district is an effective example of successful commercial revitalization and the creation of a gender-based commercial landscape. 


\author{
by \\ RACHEL ANN HARDYMAN
}

A thesis submitted in partial fulfillment of the requirements for the degree of

\author{
MASTER OF SCIENCE \\ in \\ GEOGRAPHY
}

Portland State University 


\section{TO THE OFFICE OF GRADUATE STUDIES:}

The members of the Committee approve the thesis of Rachel Ann

Hardyman presented October 29, 1992.

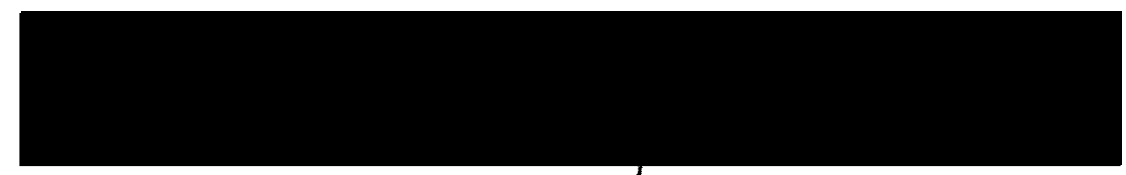

Thomas W. Harvey, Chair

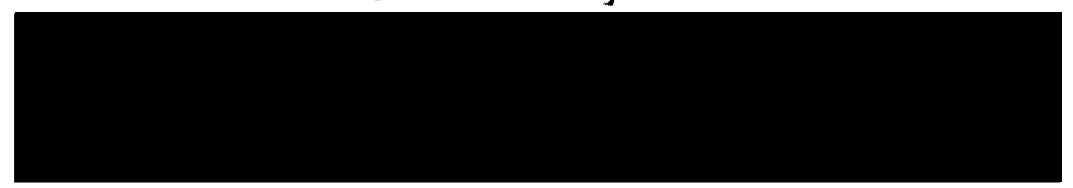

Martha A. Works

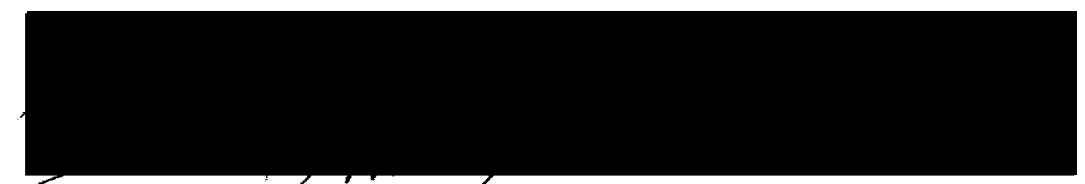

Daniel M. Johnson

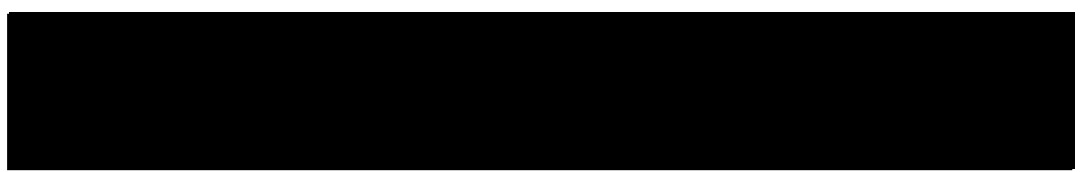

Carl J. Abbott

APPROVED:

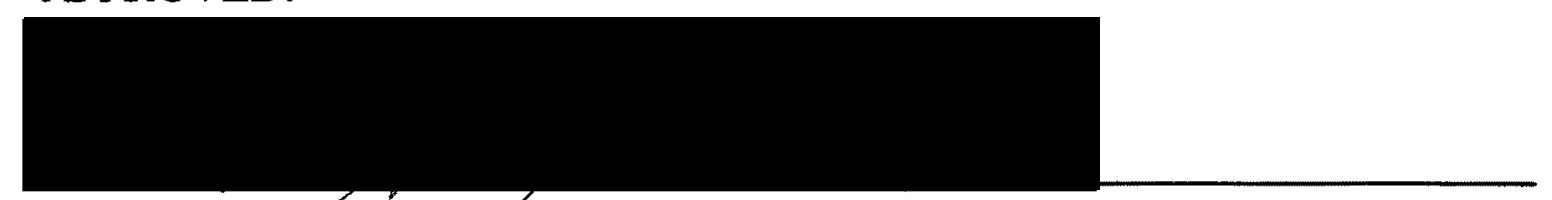

Daniel M. Johnson, Chai,, Department of Geography

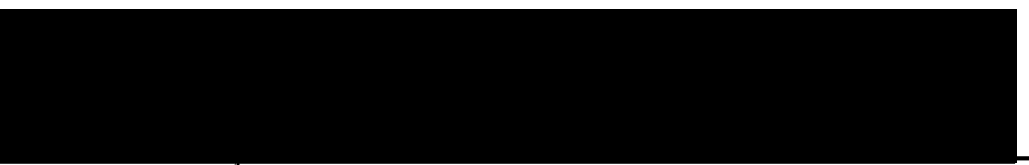

Roy W. Kqch, Vice Provost for Graduate Studies and Research 


\section{ACKNOWLEDGEMENTS}

Many people have helped me in writing this thesis. I would like to thank Cole Publications and Information Services for making their listings available to me, Carolyn Perry and Amy Benson for their encouragement and technical assistance, and Rabeca Reese for being an invaluable source of friendship, encouragement and grammatical knowledge.

Above all, thanks must go to Tom Harvey. His interest and enthusiasm inspired me to continue with my study of geography, and to become interested in the concept of landscape. Without him I would not have studied this topic nor completed this thesis. I appreciate his help and encouragement at all stages of my graduate education. 


\section{TABLE OF CONTENTS}

PAGE

ACKNOWLEDGEMENTS $\ldots \ldots \ldots \ldots \ldots \ldots \ldots \ldots \ldots \ldots \ldots \ldots$ iii

LIST OF TABLES $\ldots \ldots \ldots \ldots \ldots \ldots \ldots \ldots \ldots \ldots \ldots \ldots \ldots \ldots$ vii

LIST OF FIGURES $\ldots \ldots \ldots \ldots \ldots \ldots \ldots \ldots \ldots \ldots \ldots$ viii

\section{CHAPTER}

I INTRODUCTION $\ldots \ldots \ldots \ldots \ldots \ldots \ldots \ldots \ldots \ldots \ldots \ldots$

Hawthorne Boulevard in $1980 \ldots \ldots \ldots \ldots \ldots \ldots .9$

Gentrification .................. 12

Methodology ...................... 15

Cole Directories

Interviews

Fieldwork

Outline $\ldots \ldots \ldots \ldots \ldots \ldots \ldots \ldots \ldots \ldots, 18$

II COMMERCIAL TRANSITION $\ldots \ldots \ldots \ldots \ldots \ldots \ldots, 22$

Revitalization ..................... 26

Gentrification ...................... 35

Classification ...................... 38

III HAWTHORNE'S IMAGE ................. 50

The Hawthorne Landscape ............... 51

Stores $\ldots \ldots \ldots \ldots \ldots \ldots \ldots \ldots \ldots \ldots \ldots 6$ 
PAGE

The Feminist Image $\ldots \ldots \ldots \ldots \ldots \ldots \ldots \ldots$

Advertisements

Organized Promotion $\ldots \ldots \ldots \ldots \ldots \ldots \ldots \ldots$

A Traditional Shopping Street? . . . . . . . . . 76

An Image of Gentrification? . . . . . . . . 78

Summary $\ldots \ldots \ldots \ldots \ldots \ldots \ldots \ldots \ldots \ldots \ldots$

IV HAWTHORNE'S UNIQUE SITUATION $\ldots \ldots \ldots \ldots \ldots .83$

Geography .................... 83

The Main Street Program . . . . . . . . . . . . 90

Organization

Promotion

Design

Economic Restructuring

The Neighborhood $\ldots \ldots \ldots \ldots \ldots \ldots \ldots \ldots$

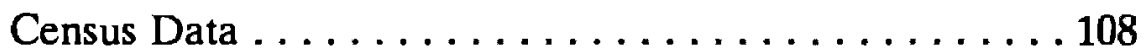

$\mathrm{V}$ THE SIGNIFICANCE OF

HAWTHORNE'S REVITALIZATION . . . . . . . . . 116

Gentrification . . . . . . . . . . . . . 117

Postmodern Society and Consumption . . . . . . . . . 122

Women and Gentrification ............. 128

Subcultural Neighborhoods . . . . . . . . . . . . 130

Summary . . . . . . . . . . . . . . . . . . 137

VI CONCLUSIONS ..................... 140 
PAGE

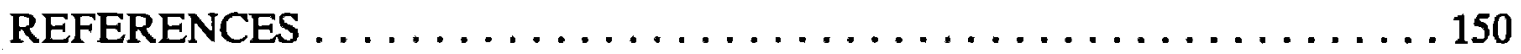
APPENDICES

A ANNUAL BUSINESS TURNOVER BY ADDRESS . . . . 155

B ANNUAL BUSINESS MIX ............... 174 


\section{LIST OF TABLES}

I Hawthorne's Changing Business Mix ............4 41

II Changes in Business Orientation since $1980 \ldots \ldots \ldots \ldots 4$

III Comparison of 1990 Census Data for Hawthorne's Five Tracts with City Medians . . . . . . . . . . . . . 109

IV Retail Change within the Metropolis ............ 136

V The Impact of Residential Gentrification on Retailing Demand . 138 


\section{LIST OF FIGURES}

FIGURE

PAGE

1. Location of Southeast Hawthorne Boulevard within the City of Portland $\ldots \ldots \ldots \ldots \ldots \ldots \ldots$

2. The Hawthorne District - Southeast 28 th to 39 th Streets. . . . . 7

3. Southeast Hawthorne Boulevard, looking east to Mount Tabor . 8

4. Advertisement for Escential Lotions, a store with branches on both Hawthorne and NW 23rd. . . . . . . . 30

5. Advertisement announcing the opening of a second Cat's Meow, on NW 23rd Avenue. . . . . . . . . . . . . 31

6. Hawthorne Place (3433-3445 SE Hawthorne Boulevard). . . . . 32

7. A vacant locksmith's store was temporarily used by Priscilla Annex in August 1992 (3616 SE Hawthorne Boulevard). . 33

8. The last vacant storefronts (3200-3210 SE Hawthorne Boulevard) were renovated in $1990 \ldots \ldots \ldots \ldots \ldots \ldots \ldots \ldots . \ldots \ldots$

9. Beaver Books, 3747 SE Hawthorne Boulevard, in early 1992. . . 37

10. Powell's on Hawthorne, 3747 SE Hawthorne Boulevard,

August $1992 \ldots \ldots \ldots \ldots \ldots \ldots \ldots$. . . . . . . . 37

11. Advertisement showing most of Hawthorne's

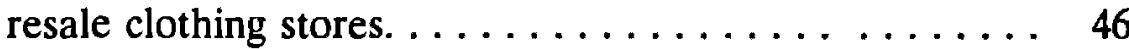


12. Many of Hawthorne's utility poles are covered with flyers .... 55

13. The Bagdad Theatre $\ldots \ldots \ldots \ldots \ldots \ldots \ldots \ldots \ldots \ldots$

14. Starbucks Coffee $\ldots \ldots \ldots \ldots \ldots \ldots \ldots \ldots \ldots \ldots$

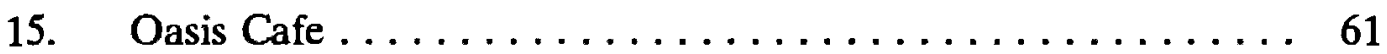

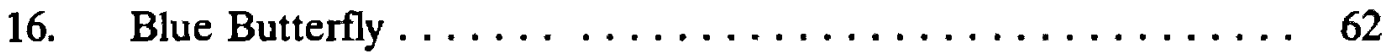

17. A page from the Feminist Broadcast Quarterly, September 1992 . 66

18. Advertisements from Ladd's Editions, Think Good Thoughts, and It's My Pleasure, reinforcing Hawthorne's

feminist and politically correct images. . . . . . . 67

19. City Glass on Flag Day. . . . . . . . . . . . . 69

20. Flags outside Fred Meyer. . . . . . . . . . . 70

21. The logo of the Hawthorne Boulevard Business Association . . . 71

22. The cover of the 1992 Hawthorne Business Directory . . . . . 72

23. Row house on 37 th and Hawthorne . . . . . . . . . . 101

24. Graffiti directed at potential row house owners . . . . . . . 102

25. The location of zip code $97214 \ldots \ldots \ldots \ldots \ldots \ldots$

26. Median household income, by census tract,

for the City of Portland $\ldots \ldots \ldots \ldots \ldots \ldots \ldots \ldots$

27. Percentage increase in median household income, by tract, 1980 to $1990 \ldots \ldots \ldots \ldots \ldots \ldots \ldots \ldots \ldots \ldots \ldots \ldots \ldots$ 
28. Percentage of population over age twenty-five with a high school diploma $\ldots \ldots \ldots \ldots \ldots \ldots \ldots$

29. Median house value, by tract, for the City of Portland, $1990 \ldots 114$ 


\section{CHAPTER I}

\section{INTRODUCTION}

[It] has not only its own cuisine but its own foreign policy ... the signs on Hawthorne Boulevard inform you in no uncertain terms that the Hawthorne neighborhood is pro baked goods and anti Contra ... the area maintains its laid-back entrepreneurialism, a kind of proscuitto perestroika (Sarasohn, in Irving 1990, p. 11).

Thus Portland Best Places describes Portland's Hawthorne Boulevard, a business district which blends the unique and the everyday in a potpourri of stores and restaurants which attracts local residents and tourists alike. Bridging the gap between being a neighborhood shopping street, a distinctive location which appeals to disparate social groups, and just another case of gentrification, 'Hawthorne' has a style all its own.

Hawthorne's primary image in the minds of the Portland public comes from its association with anti-Bush politics, environmental awareness, and the promotion of diversity. It is street of dichotomies: a retail district that abhors consumption; a district that prides itself on its pedestrian focus yet is on a busy arterial; and a neighborhood shopping street that attracts people from all over the metropolitan area.

Nowhere is the paradoxical nature of Hawthorne more apparent than in the nature of its revitalization for, while it is undergoing gentrification, it is a form of gentrification unlike that noted elsewhere. Most studies of revitalized districts 
attribute changes in the social, economic and physical fabric to a group of people the yuppies ${ }^{1}$ - for whom conspicuous consumption is a way of life; Hawthorne's character is closer to a bohemian ${ }^{2}$ lifestyle which rejects consumption. The people on the street are not the BMW-driving, fashion-conscious, wine bar set usually associated with gentrification, but a group concerned more with environmental and political issues than with what they look like or the cars they drive.

Hawthorne's eclectic assortment of stores caters to a variety of people and income levels. This has made Hawthorne one of Portland's most popular shopping districts. Although there are the galleries, boutiques and restaurants typically associated with gentrification, Hawthorne's reputation stems more from secondhand book, record and clothes stores than from upscale activities. Numerous merchants emphasize environmental awareness and encourage recycling, while others actively support current political issues. Several restaurants and stores are meeting places for the local lesbian community. It is this 'politically

${ }^{1}$ Short (1989, p. 174) notes the problem of using contemporary words in academic work: "To use yuppies ... may be the equivalent of sporting bell bottom trousers and a kipper tie to a 1970s end of term party. Trendy at the time but if pictures are taken a source of embarrassment for the years ahead." In spite of its trendiness, the term is well enough understood to be useful, and it will be discussed at greater length below.

2 The literal meaning of bohemian is "cultural radicals of a literary and artistic bent" (Godfrey 1988, p. 85). 
correct $^{\mathbf{3}}$ attitude which distinguishes Hawthorne Boulevard from other instances of central city revitalization.

Commercial gentrification, the focus of this study, is worthy of study simply because of the dearth of work in this field. Although this thesis falls within the realm of gentrification, Hawthorne is unlike most gentrified streets and, thus, supplies an informative case study from two points of view. First, it confirms that the housing and population turnover associated with gentrification is replicated in the commercial sector and, second, it demonstrates that gentrification can be undertaken by a group (or groups) other than the yuppies.

By considering retailing rather than housing this study directly addresses consumption and the evolution of consumption-based postmodern landscapes, one of the central elements of gentrification (Ley 1980; Mills 1988). Yet here again Hawthorne differs from most gentrified districts in its concentration of stores which are against consumption. Although such a statement is a contradiction in terms, because encouraging consumption is the purpose of all stores, many of Hawthorne's retailers are indeed conspicuously opposed to conspicuous consumption.

- By examining the cultural, rather than the economic, changes associated with commercial revitalization, we can gain a better insight into who the gentrifiers are and the type of district they have created. Businesses underpin the district's

3 'Politically correct' (PC) is here defined as people or businesses actively opposed to prejudice and discrimination, supportive of diversity, and conscious of environmental issues. 
image and provide direct proof of consumer demand. Hawthorne's image stems, in part, from its support of diversity consisting of its politically correct (PC) clients, the lesbian presence, and the continued patronage of long-time Hawthorne shoppers.

Yet, in spite of these unique features, Hawthorne also serves as an example of more widespread changes in societal tastes and proof of the increasing specialization of retailing. The process of physical and commercial upgrading entailed a shift of business focus from service to retail provision and from a neighborhood to a regional market. These two trends are closely linked for, while expanding its market area, Hawthorne also enhanced its connection to its surrounding neighborhoods through the move towards retailing, and regained its role as the local shopping district.

Hawthorne is an example of successful central city revitalization and may serve as an example to other commercial districts. Its renaissance was partly spontaneous and partly deliberate; the two processes complemented one another and, helped by Hawthorne's physical character and location, enabled the district to flourish.

Hawthorne is a linear retail district in Inner Southeast Portland, spreading east and west from the intersection of Hawthorne Boulevard and Southeast 37th Street ${ }^{4}$ (Figure 1). Revitalization has been largely confined to a half-mile section

${ }^{4}$ Streets crossing Hawthorne Boulevard are numbered west to east: SE 1st Street is on the edge of the Willamette River, SE 55th is where the boulevard stops at Mount Tabor. The district is always referred to as starting on its western 
of the street from SE 28th to SE 39th Street and, within this area, has concentrated on the four blocks between 34th and 38th (Figure 2). This study focuses on the eleven block Hawthorne district where most of the recent upgrading has taken place, but makes reference to locations outside this study area.

Hawthorne Boulevard is a commercial strip for almost its entire three mile length: west of 12th Street, Hawthorne runs through the Central Eastside Industrial District, a distinct subarea of Southeast Portland; east of 50th it is residential. The boulevard is unique among Portland's commercial areas in that its beginning and end are clearly defined by topographic features: the Willamette River to the west and Mount Tabor (an extinct volcano turned city park) to the east (Figure 3).

A distinction must be made between Hawthorne Boulevard and the Hawthorne retail district. When referring to the whole street, the terms 'Hawthorne Boulevard' or 'the boulevard' will be used for the purposes of this study. The study area - between 28 th and 39 th - will be identified as 'Hawthorne,' 'the district,' or 'the study area.' The Hawthorne district is focused on its 'core ' (between 34th and 38th) distinguished by several blocks of old, connected storefront buildings which reinforce a 'Main Street' atmosphere.

edge and ending to the east, probably because that is how it is approached from downtown. 


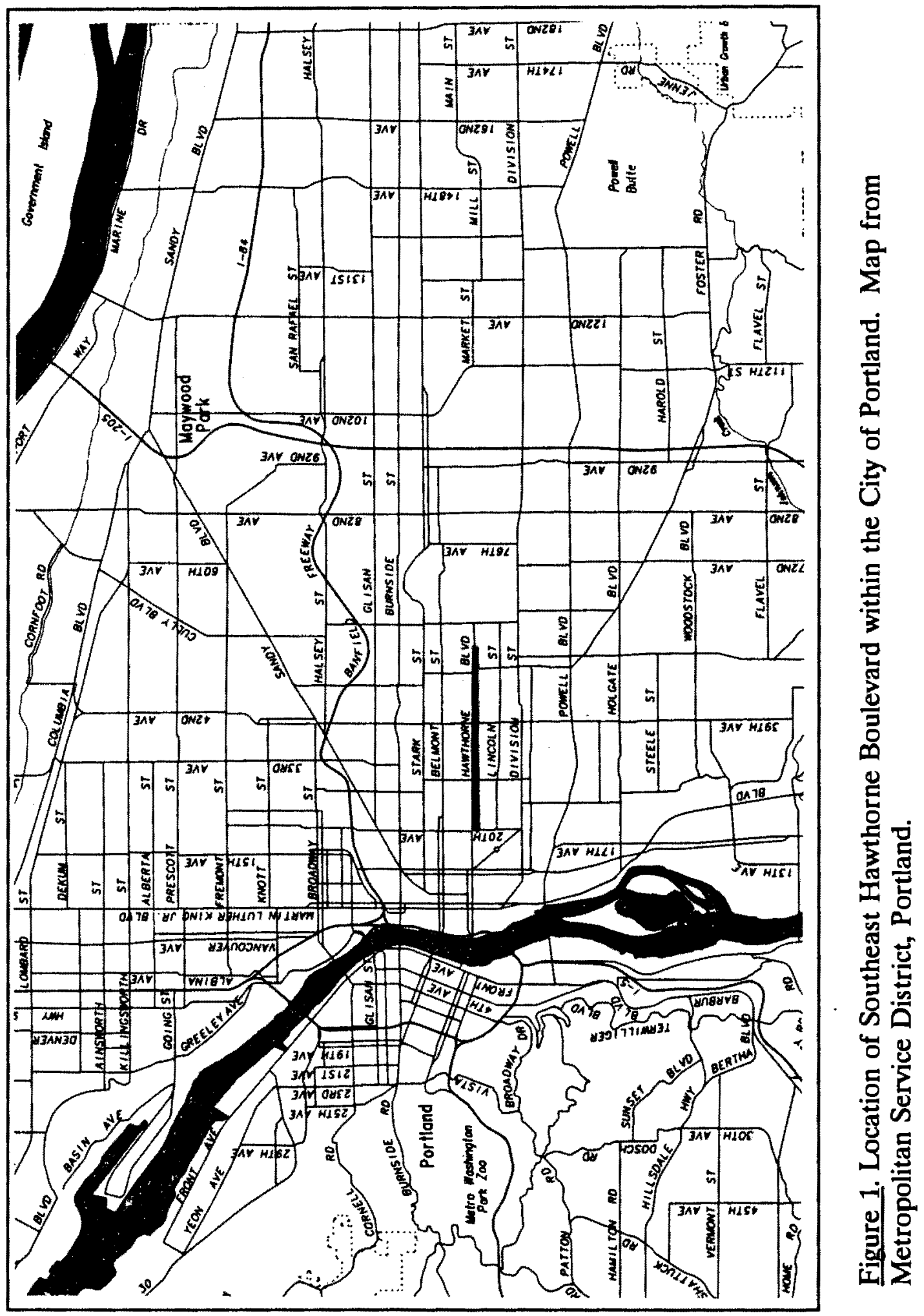




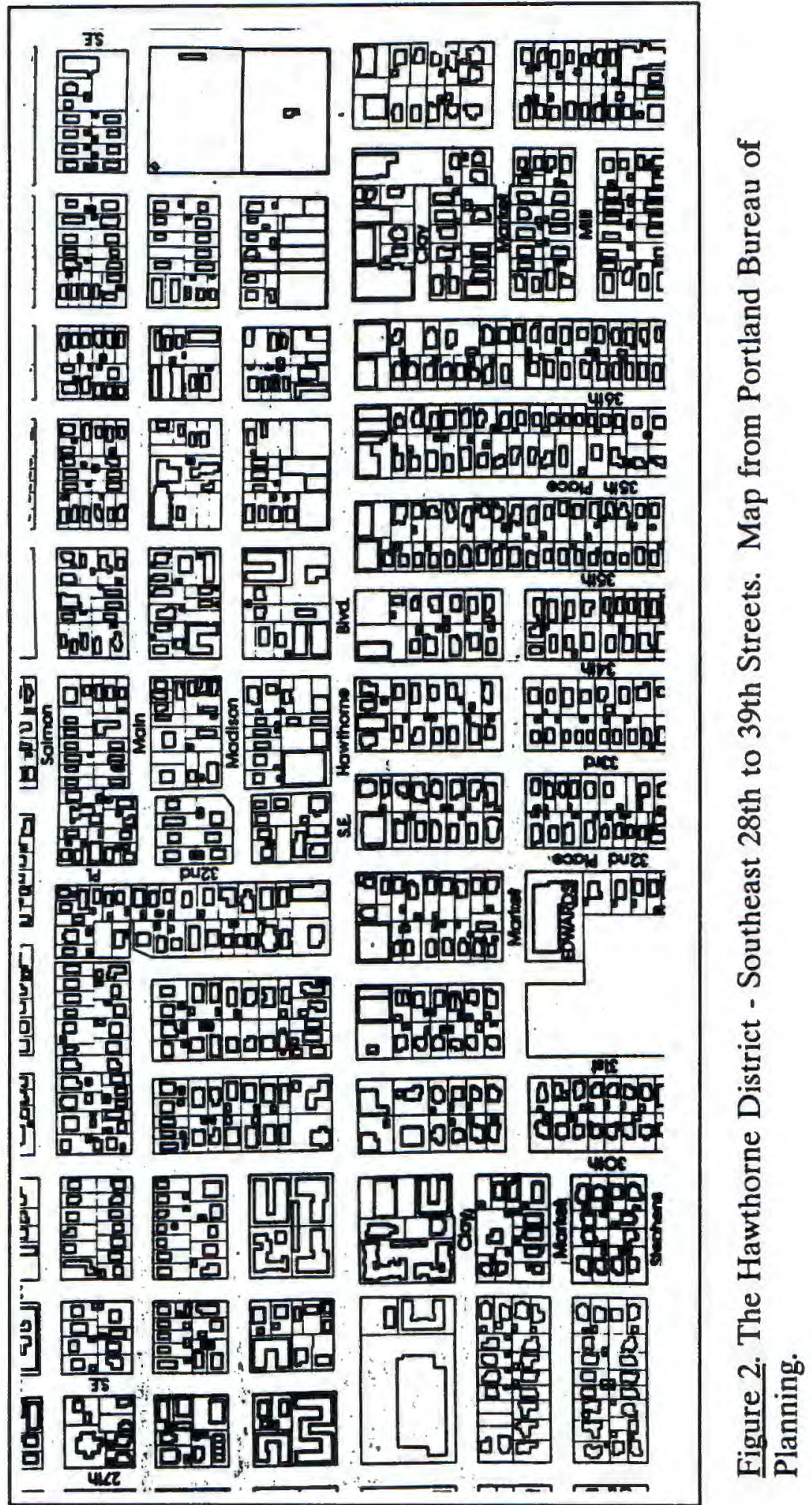




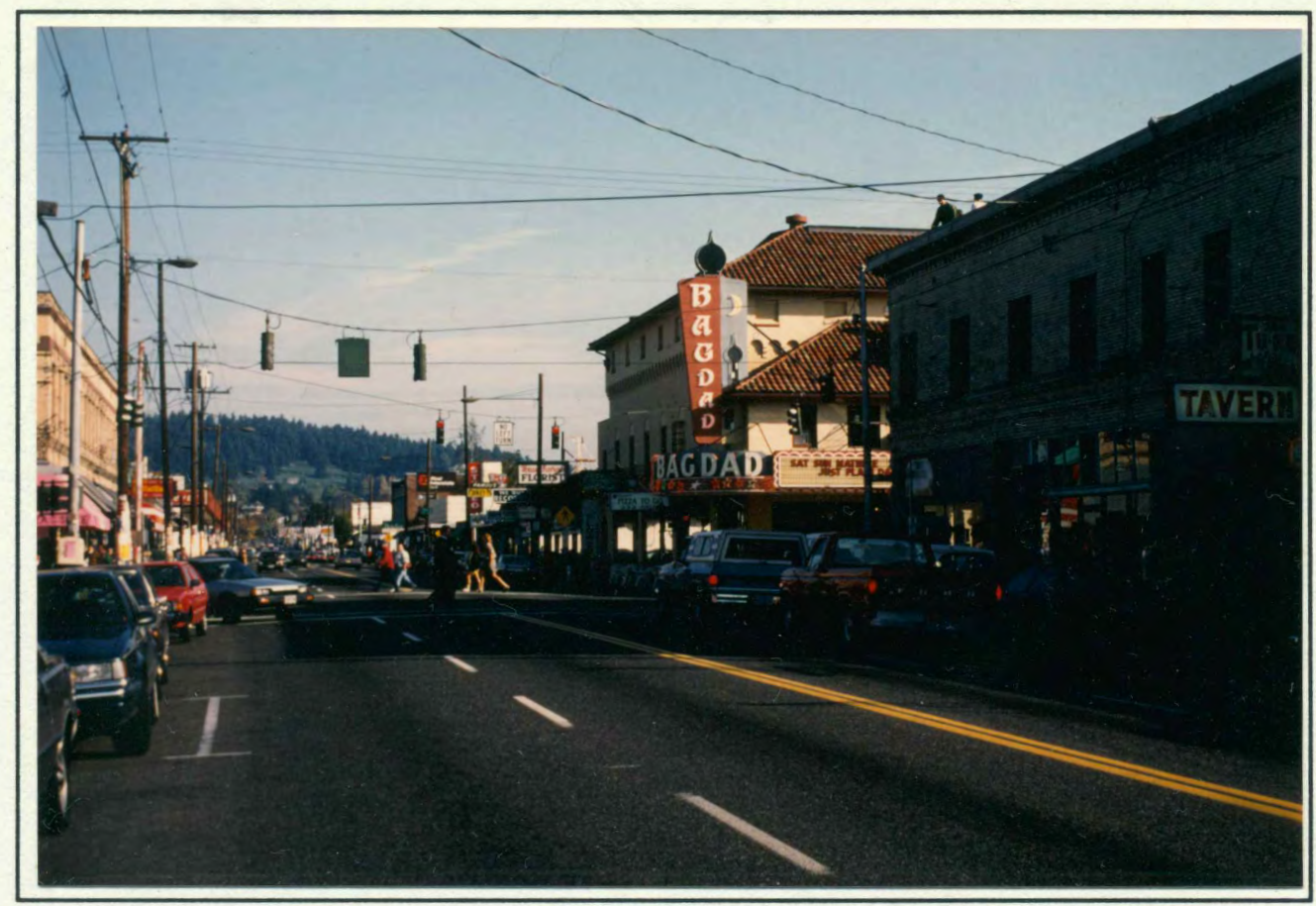

Figure 3. Southeast Hawthorne Boulevard, looking east to Mount Tabor.

The significance of Hawthorne's revitalization lies in its transformationfrom a depressed neighborhood commercial strip into a successful and attractive shopping district. The lively atmosphere and eclectic mixture of shops and restaurants on the boulevard today bears little resemblance to the Hawthorne of 1980. Analyzing the evolution of Hawthorne entails tracing changes in the business mix and describing the boulevards's revival. This introductory chapter lays the groundwork for the rest of the study by depicting the Hawthorne business district as it was in 1980. This provides a base line against which subsequent changes in both the physical and commercial makeup of the study area can be compared. 


\section{HAWTHORNE BOULEVARD IN 1980}

Information on how Hawthorne once looked is available in Hawthome Business District: Commercial District/Air Quality Report a 1981 Portland Bureau of Planning (PBP) document. This report provides a reliable picture of Hawthorne, defined in the report as SE 34th to SE 40th. Knowing how Hawthorne once looked, functioned and attracted its patrons is crucial to appreciating the transition it has undergone in the last thirteen years.

The character of businesses in 1980 will be addressed in more detail in the next chapter, yet it is worth noting something of the street's character here. At the beginning of the study period, Hawthorne found itself in the dichotomous position of being simultaneously in decline and undergoing revitalization: local merchants were closing their doors as regionally focused businesses were beginning to move onto the street. This first sign of the street's transition was greeted warily by merchants (PBP 1981). The report makes it unclear which trend dominated. Conversations with business owners indicate that, in 1980, the boulevard was in a poor state of repair but that a possible reversal of fortunes was becoming apparent.

At the time of the Bureau of Planning report, business owners spoke in "somber tones" about the future of the district. As well as falling sales, they cited high crime rates and heavy traffic as serious problems. Decline was, in part, due to changes in the nearby residential areas. The local population had fallen by over $20 \%$ between 1970 and 1980 , and its composition was changing from blue 
collar home-owners to younger, less-affluent renters. These demographic shifts reduced the number of 'convenience' shoppers frequenting Hawthorne (PBP 1981, pp. 3, 32). The resulting decrease in money available in the district's immediate neighborhoods had a serious impact on retail sales.

The opening of an adult bookstore "signal[led] the district's serious decline to members of the local business mainstream" (ibid., p. 6). Many buildings were in "shocking disrepair" and no merchants planned to expand or renovate their businesses. Apathy and decline went unchecked partly because there was no business association to pull the merchants together and coordinate activities.

As well as being in a state of physical and economic decline, the district's visual qualities were being threatened by suburban-style strip development, such as the new Arctic Circle restaurant, at its edges. Such buildings, set back from the sidewalk with large, off-street parking lots, further reduced the appeal of a pedestrian environment which was already "relatively unpleasant" (ibid., p. 14). Traffic congestion, narrow sidewalks and unattractive street furniture also contributed to a poor pedestrian climate.

In spite of the problems of physical decay and economic decline the Hawthorne business district had some positive features. Densely packed, potentially attractive buildings created a strong identity that was later used to expand Hawthorne's appeal. Noting that "[t]he visual character of a commercial district plays a role in determining the types of shops and customers that locate in or are attracted to the district" (ibid.), the Bureau of Planning predicted that 
Hawthorne's physical environment placed it in a good position to become more attractive and more successful.

Appealing buildings and an abundance of retail space provided "an opportunity to nurture numerous small specialty outlets which, when combined, greatly expand the district's trade area" (ibid., p. 13). Indeed, low rents and attractive buildings were already attracting specialty retailers in the early $1980 \mathrm{~s}$, paving the way for Hawthorne's renaissance. These businesses prospered by transcending the problems of a changing residential area, shifting their focus towards a city-wide market to such a degree that, in spite of its decline, Hawthorne "remain[ed] an active, vital business center serving Southeast neighborhoods and beyond" (ibid., p. 3).

In 1980 Hawthorne was beginning to attract shoppers from a wide area with its developing reputation for antiques, used books and stereo equipment. Since 1980 these specialties have been joined by a growing number of restaurants and gift shops that continue to characterize the district today. Hawthorne is now renowned as one of the city's foremost retail districts and proudly advertises its revival in a flyer available at the downtown tourist information office:

Although the district fell into disrepair in the seventies, the eighties saw the birth of the Hawthorne renaissance, and now it is one of the most popular attractions in the city (HBBA 1991).

This transformation of Hawthorne from a state of decline to a one of vitality is a form of gentrification: the process by which central city areas are revitalized by an influx of people who are younger and wealthier than an area's 
inhabitants. However, gentrification on Hawthorne has followed a different tack from that studied elsewhere. There are few analyses of commercial gentrification, but residential studies illustrate the cultural and economic context within which the term is usually used. These studies clarify why the experience of Hawthorne Boulevard is one of gentrification that differs from the norm.

\section{GENTRIFICATION}

Studies attribute the process of gentrification to young, white, childless professionals attracted to cheap housing with easy access to downtown. Highpaying downtown jobs and delayed child-bearing enable this group to maintain a large discretionary income and live beyond the means of their suburban peers while benefitting from the social and cultural opportunities of the central city.

The reasons behind gentrification are manifold, and it has become such a widespread phenomenon that "by virtue of its success ... we no longer know whether gentrification is primarily a social, an aesthetic, or a spatial phenomenon" (Zukin 1991, p. 193). While its origins are cause for heated debate, there is little disagreement as to gentrification's effects on the production and consumption of urban space: the renovation of old buildings is the most obvious manifestation of gentrification. Physical improvements and an increase in the neighborhood's social status attract like-minded people and raise house prices beyond the reach of the original inhabitants. This influx of the rich, and displacement of the poor, typifies gentrified neighborhoods all across the country (Hamnett 1991). 
Rejection of suburbia and the adherence to a certain definition of style sets this group of young, urban professionals, the yuppies, apart from their peers. The differences between urban and suburban cultures are addressed by Peter Hall (1975) who divides mass society along these lines, essentially the conventional and the unconventional. Urban culture is exemplified by the traditional European focus on monocentric cities with dense residential areas. Suburban culture is typified by the automobile-induced sprawl of Southern California. He suggests that the two cultures are polar opposites: "mixture versus homogeneity; concentration versus dispersion; specialization versus the middle range" (ibid., p. 167). Gentrification is a product of urban culture ${ }^{5}$.

Yuppie culture, described as "a heightened lifestyle of consumption, and a concern with the aesthetic and the realms of human sensibility" (Ley 1980, p. 247), lies behind gentrification. The proliferation of art galleries, ethnic restaurants and specialty stores in gentrifying districts bears witness to this increase in conspicuous consumption. Many residential studies make passing reference to changes in neighborhood retail space but fail to address these changes directly.

${ }^{5}$ To define 'culture' satisfactorily is beyond the scope of this paper; it will suffice to quote a definition conceived by Brian J. Godfrey (1988, p. 206) for his study of nonconformist neighborhoods in San Francisco: "culture in a general sense encompasses people's ways of life, characteristic patterns of human thought and behavior that are embedded in the geographical conditions but not strictly limited to them; subcultures, then, are specialized social worlds involving distinct ways of life, with discernible morphological expressions, within a larger pluralistic society." 
This examination of gentrification differs from most in that: 1) the focus of the study is a commercial street rather than a residential neighborhood; and 2) the gentrifiers are not presumed to be a homogenous or upscale group. The issue here is whether the concept of gentrification is applicable beyond the residential realm and beyond yuppie stereotypes.

Considering the prominence and economic significance of neighborhood retail areas, scant academic work regarding their emergence, evolution or endurance exists. Examinations of commercial districts tend to focus on central business districts, shopping malls, Main Street and auto-based commercial strips. The retail landscape has a more immediate message than do residential districts because commercial streets are highly visible, usually located on busy streets, and prone to frequent and dramatic changes (Jones and Simmons 1987, p. 4). Similarly, business change provides tangible evidence of transformations more distinct than those in residential areas. Because business evolution "both reflects and presages broader changes" (Godfrey 1988, p. 191) a district's success or failure reveals neighborhood trends.

Retail landscapes provide a window into the lives of their clientele.

Altering a building takes much time and money and is undertaken fairly infrequently, but the temporary contents of a store may change daily, monthly or yearly. Successful businesses are those that most effectively fulfil the needs of their customers and, thus, the preferences and expectations of consumers are reflected by fluctuations within the business community. Indeed, "[t]he retail 
landscape both reflects and reveals the social system in which it is embedded" (Jones and Simmons 1987, p. 1).

The volatile landscape of the retail environment exhibits a fluidity of form and function that tells the observer much about large-scale society and its passing trends. As the changing mix of businesses provides insight into consumer demand, so window displays - the cheapest and most direct form of local advertising - and merchandise portray the image that the merchant creates and sells. Retailing is worthy of study within the realm of cultural geography, in addition to its prominence in economic geography, because of the importance of consumption to the American way of life. Indeed, "North Americans have created a juggernaut of consumption: a combination of expectations and lifestyles that drives the entire economy" (Jones and Simmons 1987, p. 120).

\section{METHODOLOGY}

Commercial revitalization is at once a physical, social, economic, and cultural phenomenon and, as such, cannot effectively be approached from only one direction. Physical improvements and changes in the business mix serve as both cause and effect in the creation of a sense of place: the resultant image is what attracts, or repels, potential customers. To describe businesses turnover, commercial transition, and the creation of Hawthorne Boulevard as a place, data used in this study come mainly from three sources: Cole Directories (1980-1992), interviews, and fieldwork. 


\section{Cole Directories}

These directories, published each May, list all registered telephone users, both residential and commercial, by their address. This simplifies the process of tracing changes of tenancy from one year to the next. In this case, names and addresses of businesses on, or within one block of, Southeast Hawthorne Boulevard were recorded for all thirteen years of the study period ${ }^{6}$.

As the primary source of quantifiable data, these directories provide an impartial picture of annual business turnover. However, some problems exist in using these data as accurate representations of the past. The listings are annual snapshots of the street; businesses that survived on Hawthorne for less than one year may not be recorded. Moreover, possible errors exist in the listings. Still the directories provide largely accurate and consistent information adequate to determine general trends.

It is impossible to determine exactly when a business arrived on the street because Cole Directories specify only the first year in which an entry was listed. (The organization claims $85-90 \%$ accuracy in its 'first year' listings.) For the purpose of analysis I assume an enterprise arrived on Hawthorne the calendar year before its first Cole listing. Any inaccuracies caused by this assumption are consistent throughout the dataset and do not affect the overall profile of transition.

Occasionally an address is not listed for one or more years. I work around

${ }^{6}$ Data used with the permission of Cole Publications, Portland. 
this using a number of assumptions: 1) if the missing address reappears in subsequent years, with a different business name, the property was vacant during the unlisted year(s); 2) if the original business name reappears there was a typographical error in the missing year; 3) if the address never appears again, buildings were renumbered, torn down, or are still vacant.

In looking at upgrading within the business community, names of businesses provide much of the evidence needed to evaluate revitalization. One can make assumptions about former business types from their name alone: in many cases this is easy to do (e.g. Ride On Skateboards, Mary's Jewelry, Melissa's Kitchen). Where a name gives no hint of business type I have classified it as 'Other' (e.g. The Whole Image, The Midas Touch, Windy City). Annual changes, by address, are listed in Appendix A.

Minor inaccuracies in both the listings and their subsequent classification are insignificant. The purpose of this study is not to provide a complete list of all businesses but to use past records to gain a general understanding of the changing commercial structure of Hawthorne Boulevard. The broader pattern of succession matters more than do precise details. The directories clearly show a transition from services to retailing, and from ordinary to specialized goods.

\section{Interviews}

Business and property owners on Southeast Hawthorne Boulevard were able to help me identify some of the older businesses listed and, often, provide reasons for their departure. I interviewed several merchants, covering all 
categories and lengths of residence in the district, to obtain their views on the process of revitalization. This information provides a useful account of upgrading as seen by those most directly affected. Views expressed at these informal interviews are incorporated into the text.

\section{Fieldwork}

Over the past six months I have spent much time on Hawthorne Boulevard keeping track of the continuous flux of stores. Such observation helps in the definition of store types and in determining which shops and restaurants attract a similar clientele. Walking along the street or sitting watching people provides the best evidence of what 'Hawthorne' is and why it succeeds. Chapter III presents the contemporary image of Hawthorne Boulevard. All the photographs presented here were taken during the spring and summer of 1992.

\section{OUTLINE}

This study describes the changes that have resulted from three parallel trends affecting the business mix: 1) the change from service businesses to retail; 2) the shift from a neighborhood to a regional focus; and 3) commercial upgrading. Chapter II looks at how the business mix has progressed along these three continua by classifying businesses and tracing annual changes in the makeup of the district. This information is used to define a 'tipping point' at which revitalization became gentrification, and to illustrate how specialized stores and restaurants are displacing neighborhood businesses. 
Transformation from a neighborhood service center to a regional shopping and restaurant district entailed simultaneous improvements to the built environment and altered Hawthorne's image. Chapter III describes how these changes influenced the landscape and the sense of place associated with the district. The interpretation of 'landscape' used here comes from Relph's (1987, p. 238) definition of 'townscape' (the urban landscape): "a layman's view of a street with buildings, signs, trees, parking spaces and people, all together." Add to this the contents of buildings (i.e. the types of stores) and 'landscape' encompasses all aspects of a given scene: the permanent (buildings), the temporary (stores) and the mobile (auto and pedestrian traffic).

Once the shifts in Hawthorne's character, both built and unbuilt, have been identified, Chapter IV explains why Hawthorne Boulevard, rather than any other district in Portland's eastside, experienced these changes. The broader picture how this case study of commercial revitalization relates to other studies - is addressed in Chapter V. The final chapter summarizes the transformation that has taken place and draws some conclusions about the process of commercial gentrification.

Three further features which contribute to Hawthorne's contemporary image should be mentioned here. These are the Main Street Program, the process of feminization, and the relationship between Hawthorne and Northwest 23rd Avenue. The first two are important elements in setting Hawthorne apart from other commercial streets; comparisons to NW 23rd emphasize how 
Hawthorne is both similar to, and different from, Portland's preeminent gentrified retail street. Although these three elements are not explicitly addressed until later chapters, each one has affected Hawthorne's image and is referred to throughout the early part of this thesis.

Primary among these is Hawthorne Boulevard's participation in the Main Street Program, an organized plan aimed at the revitalization of small town Main Streets and the neighborhood commercial districts of larger cities. The program had a hand in the redevelopment of Hawthorne between 1985 and 1988, providing assistance for the renovation of buildings, the attraction of new businesses, and the promotion of the district throughout Portland. The Main Street philosophy guided the actions of the Hawthorne Boulevard Business Association and speeded up the process of revitalization. Details of the Main Street Program are discussed in Chapter IV.

Of less significance to the revitalization process, but more apparent today, is Hawthorne's focus on women and its patronage by the lesbian community. Being a feminist commercial strip distinguishes the district most clearly from other commercial areas in Portland. A large number of the stores and restaurants on Hawthorne are owned by politically active women, and several businesses serve as social centers for the lesbian community. This inclination is self-reinforcing: as its reputation strengthened so the district is 'feminized.'

Finally, Northwest 23rd Avenue has an indirect impact on Hawthorne. Because NW 23rd was the first commercial street in Portland to undergo 
gentrification it has become the standard against which other streets are measured. Although NW 23rd conforms more closely to the norms of gentrification than does Hawthorne, the two have many things in common. Each street is the focus of specialized retailing on its own side of the Willamette River; several stores have branches on both streets and others have moved from NW 23rd to Hawthorne when rents became too high. The former is described in Chapter III, but referred to throughout this thesis to emphasize the connections between the two districts.

This is a study of successful revitalization. Specialization and an expanding market area have made Hawthorne more prosperous, yet have not alienated the local population. The neighborhoods surrounding Hawthorne are, in fact, culturally closer to the commercial district than they were in 1980 because Hawthorne is now more representative of the social environment around it. Rather than being priced out, as is often the case in gentrification, local residents have benefitted from the improvements on Hawthorne and now have a vibrant shopping district which represents the interests of a large portion of the neighborhood. 


\section{CHAPTER II}

\section{COMMERCIAL TRANSITION}

That Southeast Hawthorne Boulevard has undergone revitalization is undeniable; whether these improvements truly constitute gentrification is a more contentious issue. In this chapter, I outline the differences between revitalization and gentrification, trace changes in the business mix, and consider the nature of that change. I conclude that Hawthorne's revitalization was sparked by the ten storefronts that became vacant in 1983 , following the departure of a furniture store, and that revitalization became gentrification in 1990 , once all the district's vacancies were filled.

There is a thin line between revitalization and gentrification, with the former being seen in positive terms, the latter often interpreted in negative terms: revitalization gone too far. This begs the question 'when does revitalization become gentrification?' And is there a 'tipping point' beyond which changes are no longer mere improvements but serve to further erode neighborhood retailing? To answer this question, the differences must be clarified and then applied specifically to the case of Hawthorne.

Neighborhood commercial revitalization entails improvements to the physical and design elements of a district which, in turn, strengthen connections with the surrounding residential areas and enhance neighborhood self-esteem. 
Businesses are encouraged to move into vacant or under-utilized buildings, filling both the physical and the service gaps in the retail structure. Revitalization programs stress the importance of attracting local residents back to their local shops, and away from out-of-town malls (Glisson 1984).

In contrast, gentrification can destroy neighborhood shopping streets by completely replacing convenience stores with expensive boutiques and galleries. Although little has been written about commercial gentrification one can assume the process to be similar to the residential process: just as gentrifiers push the original inhabitants out of residential areas, so expensive shops push neighborhood businesses out of commercial properties. When low order goods are displaced by high order goods, the district's market area is expanded beyond the immediate vicinity to a city-wide range.

This shift away from the neighborhood is a major facet of commercial gentrification and with it comes a younger, wealthier clientele. Attracted by the physical, social and cultural amenities of the city, the galleries, boutiques and highclass restaurants of revitalized inner districts, these urbanites attract yet more specialty businesses. Increases in rent and an altered customer base eventually force low-level businesses to leave. A spiral of conspicuous consumption is thus established and the gentrified district becomes a center for young, image-conscious professionals living outside the area.

This chapter draws attention to the salient features of Hawthorne's commercial progression by focusing on the issue of gentrification and on those 
aspects of the business mix which define the district today. Beginning with the business mix of 1980 , change over time is addressed with particular reference to the district's noted specialties of books, music and restaurants. A two-fold classification system used later in this chapter clarifies the changing types and orientations of Hawthorne businesses, and provides an overall picture of the transition. A tipping point will be defined at which revitalization advanced to gentrification.

Commercial transition associated with Hawthorne's revitalization has occurred in two distinct ways. Since 1980 lower order goods and services have gradually disappeared from the street as the number of specialty stores and restaurants has increased. Simultaneously, there has been a redefinition of the area's style and ambience because revitalization has been associated with a growing political correctness. Many new businesses promote environmental awareness and cater both to the trendy 'politically correct' (PC) and to those for whom the 'sixties' never ended. The street's image today is based on this ecological consciousness and the promotion of diversity. These traits, as well as Hawthorne's city-wide reputation for antiques, music stores, used books and restaurants, are emphasized in the following summary.

The initial discussion is limited to the Hawthorne district (SE 28th to 39th Streets) as this has been the section of the boulevard most affected by upgrading. The types of businesses coming in, however, rather than the rate of turnover, make commercial revitalization significant. Business turnover, in and of itself, is a 
continual process so pervasive as to be insignificant to the thesis of upgrading presented here. The simple rate of change in the study area has been no greater than anywhere else on the boulevard. Changes in business type must occur on a fairly large scale to lend credence to the notion of commercial progression: where a single shop modifying its function may be proof of nothing more than new ownership, when many stores change style or are replaced by 'higher' uses, it is indicative of more significant changes. The district's evolution from a provider of local services to the center of East Portland style is shown in this synopsis of turnover.

Describing Hawthorne's core as it was in 1980 establishes a starting point from which progression towards today's revitalized position can be traced. At the beginning of the study period the district was already noted for its concentration of specialty stores (PBP 1981) which formed a small, but growing, presence in a district that still focused on local demands for convenience and household goods. Of the 104 businesses listed in 1980 there were four book stores, nine music stores (records, instruments and stereo equipment), and three antique shops. Specialist businesses on Hawthorne included a shop selling handmade lampshades (Yestershades), a skateboard shop (Ride On Skateboards) and a yarn shop (The Knotting Chamber). Combining the specialty, music-related, antiques and book stores categories shows that $28 \%$ of the businesses had a non-local focus.

However, twenty-one businesses still catered to a local 'convenience' market, with a further ten concerns providing household goods such as carpets 
(Kahl's Carpet Fashions) and furniture (Union Furniture), as well as plumbing (Bedlion and Hellums Plumbing) and glazier services (City Glass). Hawthorne's business mix also included a garage (Danderoo's Auto Repair), TV repair (Wistings) and a wholesale uniform vendor (Harris Uniforms), all of which have since left the boulevard.

\section{REVITALIZATION}

During the first three years studied four antique shops opened, doubling the number in the district and confirming the street's developing image as a specialty center. Other new business included, in 1980, two bakeries (The German Bakery and Bread Spread) and the short-lived Ted's Carpet Service; two music stores (Rollins Records and Precision Guitar Repair) and a book shop (The Uncommon Reader) opened in 1981. The progression continued with the 1982 appearance of a gourmet wine and coffee shop (Liquid Assets) and The Boulevard Deli.

In the same period a Christian Science Reading Room and The House of Linoleum left the street. The latter's location became an antique store and now contains Powell's Books for Cooks. This one location illustrates the development of commercial gentrification: a long-standing service business was replaced by a specialized, but relatively inexpensive, retailer which, in turn, was replaced by a yet more specialized store aimed at the conspicuous consumer.

In 1983 Union Furniture moved away from Hawthorne Boulevard initiating 
the biggest single transformation seen during the study period. The company sold unfinished furniture, and used several buildings - comprising ten storefronts - for storage; these temporary warehouses were poorly maintained or boarded up. Union Furniture's departure (it moved to SE 82nd Avenue) freed several low rent storefronts for new businesses to move in.

Into the vacant furniture store moved Ruby's Antiques from its smaller site three doors away. The Bread and Ink Cafe, "a neighborhood restaurant that created its neighborhood around it" (Irving 1990, p. 29), moved into Union Furniture's main warehouse; and the Hawthorne Coffee Merchant took Ruby's previous space. Within a few months Peter de Garmo and Don Oman established Pastaworks - a Mediterranean deli - nearby. It has since become one of the classiest retail outlets on Hawthorne, yet in spite of having regional and national business, still retains its local customer base ${ }^{1}$.

Pastaworks and Bread and Ink are now regarded as the 'pioneers' that blazed a trail for other to follow; several upscale businesses also opened their doors in 1983 and helped Hawthorne's image tremendously. This was a turning point for the district; in the same year two art galleries (Graystone Gallery and Rose City Art Center) also opened. Yet not all new ventures were of this genre. A thrift store opened and Hawthorne became home to a Macheesmo Mouse 'healthy fast-food' restaurant and the Echo Theatre, a lesbian theater company. After the flourish of activity in 1983 , the street stabilized at this higher level

${ }^{1}$ Personal communication with Peter De Garmo, co-owner of Pastaworks. 
of specialization created by the upscale stores. In 1984 retail specialization continued with the establishment of another antique store (this one survived only a year) and another music store (Orpheus Compact Discs). The Adult Center the adult bookstore whose appearance was noted in 1981 as signalling decline on the street - was not listed in 1984. However, there was an adult bookstore doing business at the same location until early 1992. It is not clear whether the store went out of business or did not have a listed phone number for a number of years. An example of Hawthorne's transformation was George's Bagdad Shoe Repairs move from its prime location on 37th and Hawthorne around the corner to 37 th Street. Its original spot was filled by a video rental store. As Hawthorne's focus shifted from neighborhood services to retailing and recreation, non-retail enterprises such as the shoe repairer left the district. In 1985 the shoe repairer moved again, out of Hawthorne's retail core to the east side of SE 39th where he is today. In 1986 Harris Uniforms left Hawthorne and Wisting's TV Repair moved east to SE 46th. The Wistings sign is still in its original location at SE 30th Street.

In 1985, Tabor Hill Cafe "an important anchor for revitalized Southeast Hawthorne Boulevard" (The Oregonian April 26, 1992) took over an old deli. Located in an unassuming red-brick building at the far eastern end of the district, Tabor Hill is a "bustling neighborhood dining spot" (ibid.) with a city-wide reputation for Northwest cuisine. It has helped Hawthorne gain a reputation as Portland's "food mecca" (Irving 1990). 
At the other end of the culinary scale, Don Juan's Mexican restaurant went out of business in 1986 after years of complaints from neighbors. It was finally forced to close following a murder in the parking lot and several drug raids by the police. Merchants note the passing of Don Juan's as one of the major improvements seen on Hawthorne. Its building remained vacant for several years then was revamped as a health clinic in 1989.

Many of Hawthorne's currently popular stores also appeared in 1986. Artichoke Music (which moved from NW 21st because of high rents), The Cat's Meow (everything imaginable to do with cats) started on a side street and has since moved onto Hawthorne itself, Visible Impact (resale clothing), Bowers Bakery and El Mundo For Women (cotton clothing) all arrived on the street within a year of one another. Guitar Crazy and Crocodile Records helped reinforce the street's reputation for music stores, while Timeless Treasures (handmade gifts) and Della's Deco Ware bolstered specialty retailing.

Harris Uniforms' location was taken over by the Neon Art School in 1987. It is one of the few non-retail functions to open since 1980, perhaps because it fits in with the general species of Hawthorne businesses: neon and commercial gentrification seem to go hand in hand. Neon signs are increasing in prominence on the boulevard, but there are still relatively few when compared to NW 23rd.

Environmental awareness was represented by the offices of Greenpeace, the Portland Central American group, Peace, and Escential Lotions which sells animal-free cosmetics in refillable containers. The proprietor of Escential, Meg 
Mann, chose Hawthome for her second store (the first is on NW 23rd - see Figure 4) because it reminded her of neighborhond shopping streets in Berkeley. She was atracted to the street by the success of Pastaworks as well as all the book and music stores ${ }^{2}$. Indeed, Pastaworks' emporium was completed when Powell's Book for Cooks and Salumeria Di Carlo (hand-made sausages) moved into the same building in 1987, creating the most sophisticated enterprise on Hawthorne to date.

In 1988 Guitar Crazy moved from the core to SE 17th and Hawthorne (where it remains today), and The Cat's Meow moved from its side-street location to a more prominent position on the corner of SE 35 th. The success of The Cat's Meow is such that it opened a second store in September 1992, on NW 23 rd

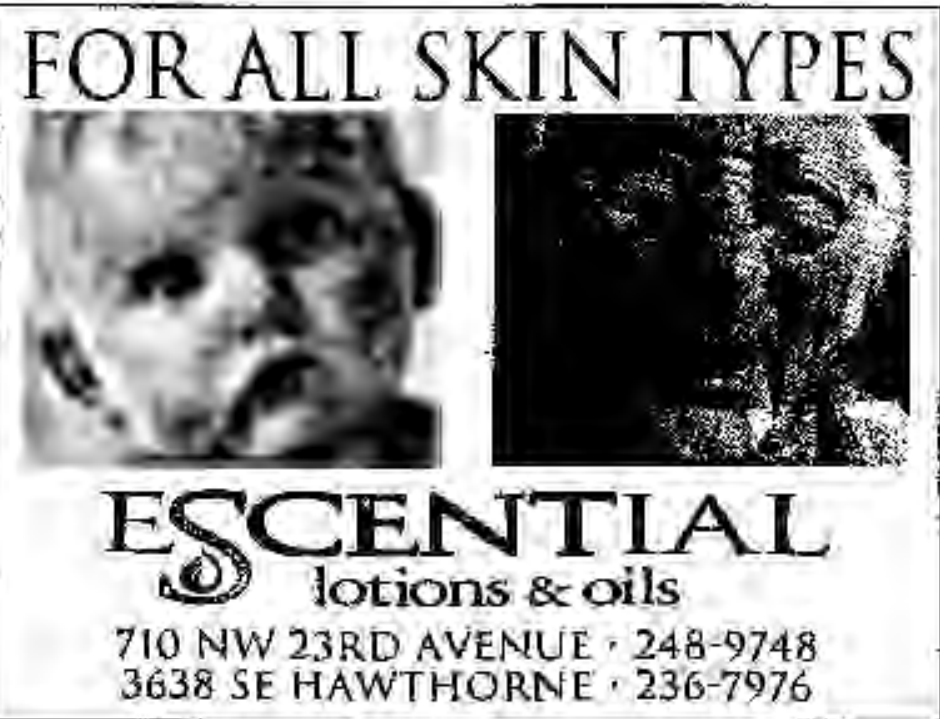

Figure 4. Advertisement for Escential Lations, a store with branches on both Hawthorne and NW 23rd. (From lacal newspaper.)

${ }_{2}^{2}$ Personal communication with Meg Mann, owner of Escential Lotions. 
(Figure 5). Two new restaurants - A D Quan Vietnamese and Oasis Cafe (pizza by the slice) - and Second Story Books also started in 1988.

The business mix took a large step towards specialty retailing with the 1988 construction of four 1,000 square foot retail units on a vacant lot once occupied by Danderoo's Auto Repair (HBBA August 1988). In one move the street lost an unattractive building, gained 'Hawthorne Place' (3433-3445 SE Hawthorne) and four new specialty stores (Figure 6). The owner of a convenience store franchise

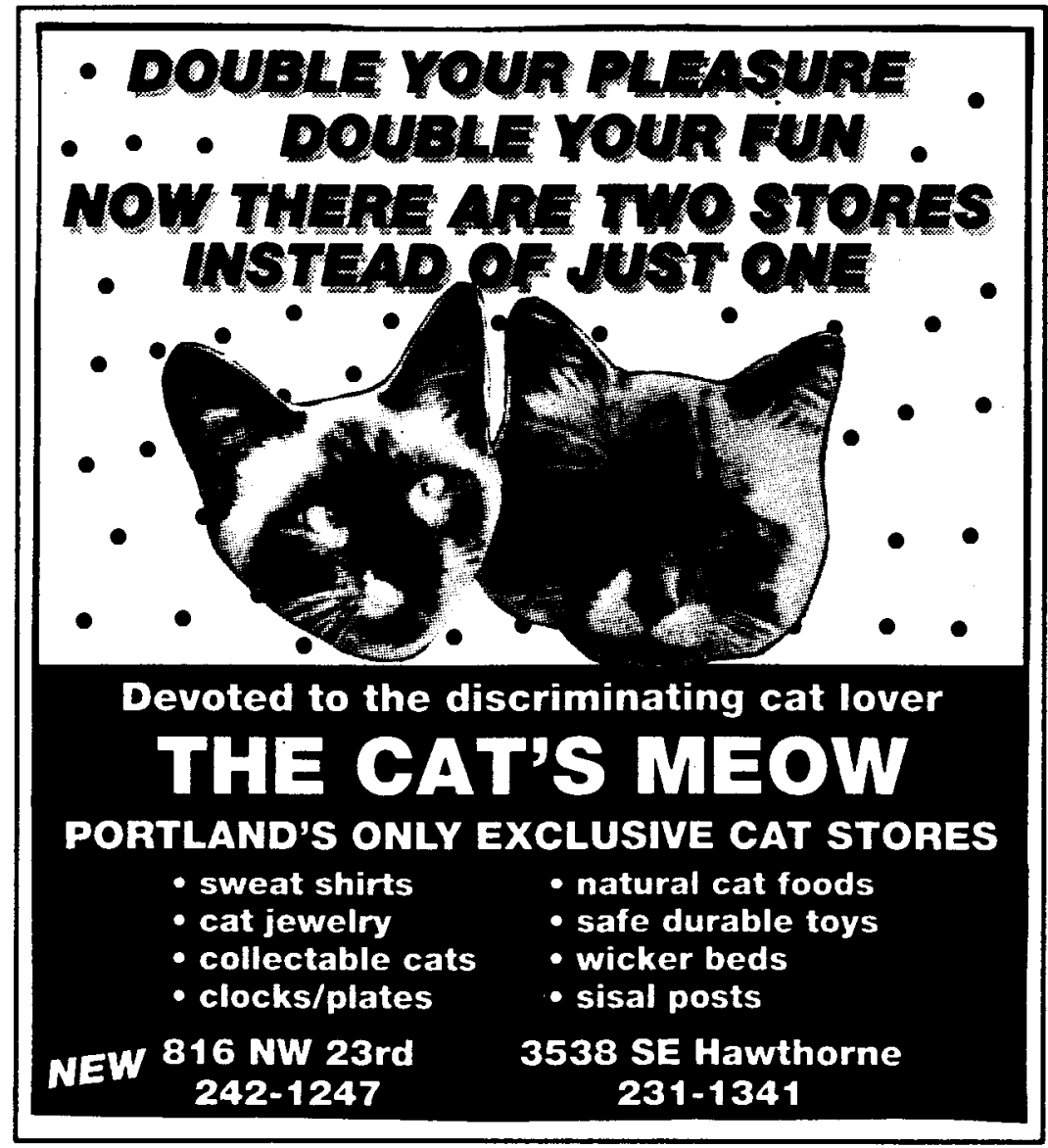

Figure 5. Advertisement announcing the opening of a second Cat's Meow, on NW 23rd Avenue. (From local newspaper.) 
had wanted to turn the gas station building into a Quick Mart, but intense neighborhood opposition overturned his plans ${ }^{3}$. Hawthorne Place now houses four specialized stores: Nibbles (frozen yogurt), Priscilla Ann (women's clothing), Man's Best Friend (gifts for dogs and dog lovers) and Northwest Futon Company. Until August 1992 Priscilla Ann had a second store in the district - Priscilla Annex. The latter went into liquidation and its location was taken over by Egads! (1950s clothing and memorabilia). The remaining merchandise from Priscilla Annex was moved across the street to a vacant locksmith's store (Figure 7) and sold at reduced prices.

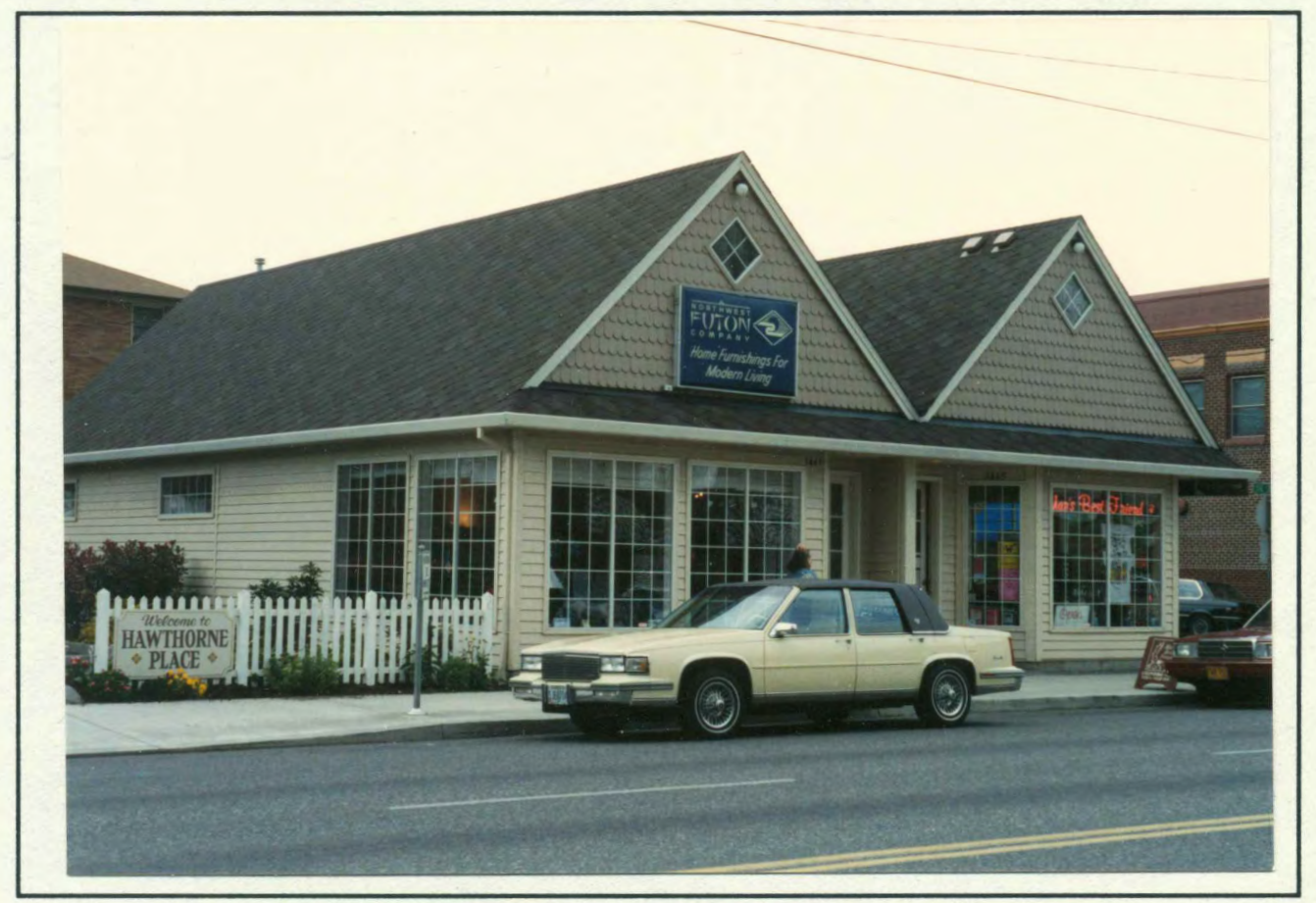

Figure 6. Hawthorne Place (3433-3445 SE Hawthorne Boulevard).

${ }^{3}$ Personal communication with Michael Emert, owner of the Douglas Building, 3525-3541 SE Hawthorne Boulevard. 
The 1989 closure of a Kahl's Carpet Fashions and the Bagdad Tavern left a large building vacant at the northwest corner of 37th and Hawthorne. In keeping with the trend towards small-scale specialty retailing, the property was restored to its original configuration of six storefronts (HBBA October 1989). These were rented by a variety of stores including Presents of Mind, Holy Cow (gifts) and Rose Sitka (antiques).

Starbucks Coffee took the corner position in this revamped building. It is the most obvious corporate presence in Hawthorne's core; others business chains are Macheesmo Mouse, Powell's Books, and McMenamin's brew pubs.

Starbucks's corporate appearance distinguishes it from these other businesses.

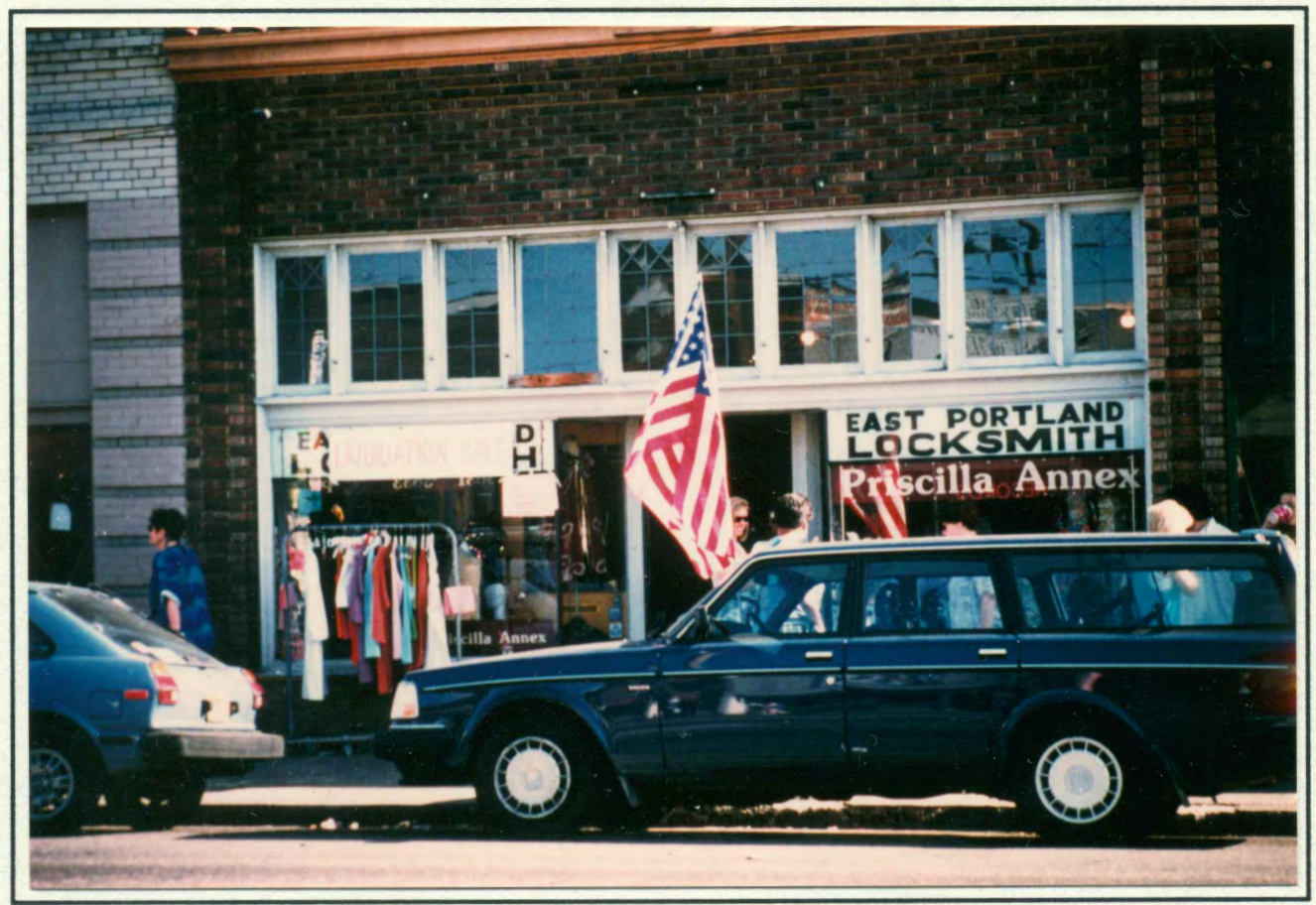

Figure 7. A vacant locksmith's store was temporarily used by Priscilla Annex in August 1992 (3616 SE Hawthorne Boulevard). 
The other chains ensure each of their branches has a different character, whereas every Starbucks has the same decor and atmosphere.

Together with the Cup and Saucer Cafe, which also opened in 1989, Starbucks has encouraged street life with sidewalk tables and chairs. The two cafes attract different clientele and provide nodes for the two divergent groups currently visible on Hawthorne. Starbucks is associated with the style-conscious yuppie crowd (although its customer base is much broader), Cup and Saucer is the most openly lesbian business in the district, and is frequented predominantly by earth-conscious, PC, customers.

In the same year these two cafes operied, the last vacant storefront building (3200-3210 SE Hawthorne) was renovated (HBBA October 1989). This now houses six businesses, adorned with matching awnings (Figure 8), which perhaps typify Hawthorne's image as it is today: three clothing stores (two 'resale'), a book store, a dried flower shop and an art gallery concentrating on the female form.

In 1990 Hawthorne reached a point where its renovation seemed complete: many building facades had been remodelled, and all vacant buildings in the core had been refurbished and rented to new tenants. This revamped image, combined with the disappearance of local service industries and an increasing number of specialty stores had brought the boulevard back to life and greatly increased the foot traffic. The district was in good physical and economic shape, most definitely 'revitalized,' and any further improvements can be regarded as gentrification. 


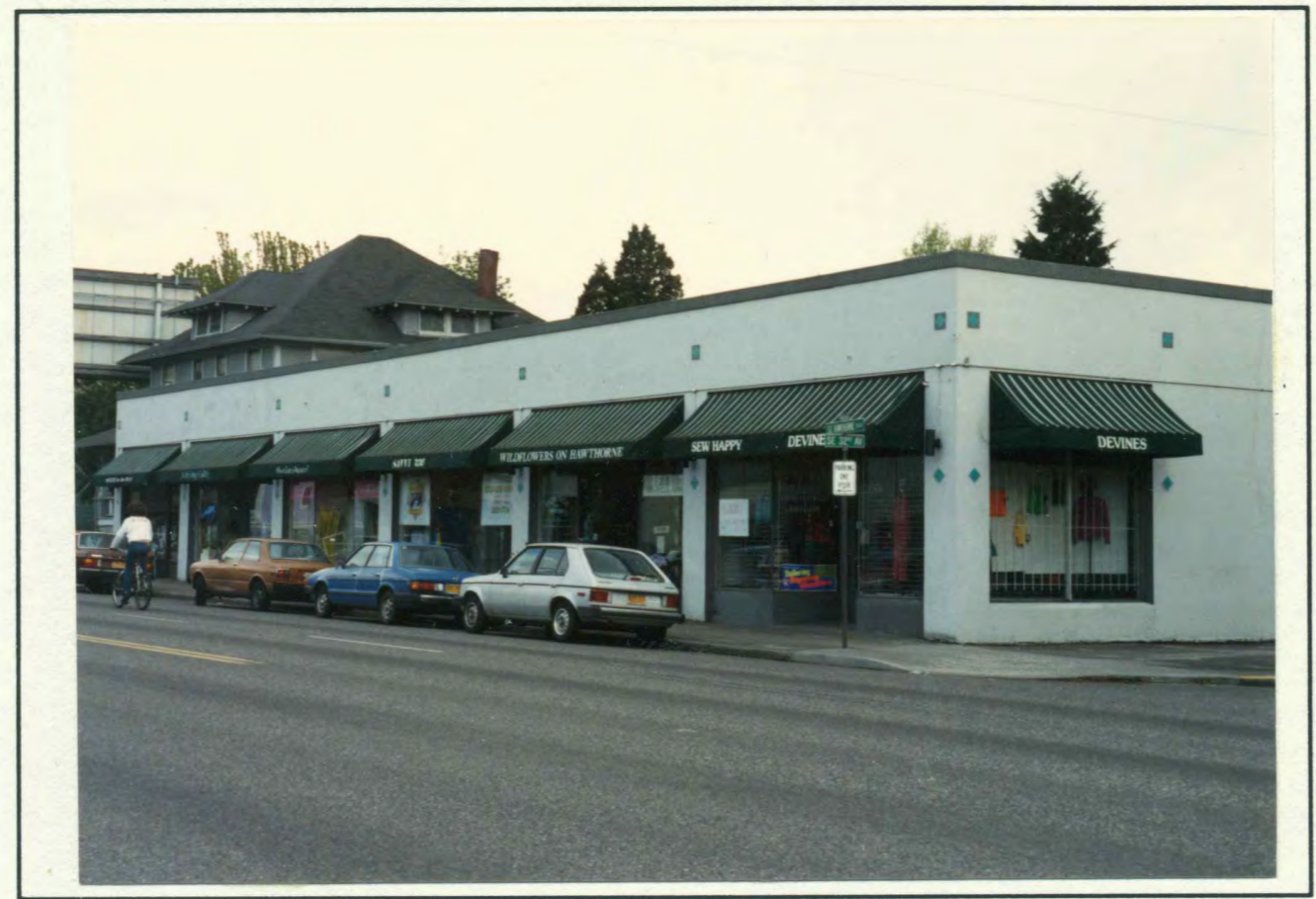

Figure 8. The last vacant storefronts (3200-3210 SE Hawthorne Boulevard) were renovated in 1990.

\section{GENTRIFICATION}

Gentrification began in 1991 with the purchase of the Bagdad Theatre by McMenamins, Portland's brew pub giants. Because of its size, location and function, its transformation into a successful one dollar movie house and microbrew pub has had a dramatic effect on the vitality of Hawthorne's core. Although it is unfair to attribute the tipping point on Hawthorne to one business, the renovation of the Bagdad Theatre was such a boost for the street that its significance should not be underestimated. The reopening of this entertainment magnet was the first indication of a recent burst of activity that has pushed 
Hawthorne to a higher degree of specialization. Subsequent changes have led to the displacement of service businesses by specialized retail uses.

A prime example of this new level exists in the Bagdad Theatre building itself. The large storefront was occupied by First Stop Video Rentals until the building changed hands. This store - which had taken the site from a shoe repairer in 1984 - moved across the street, displacing McGee's Blinds and Awnings. McGee's moved out of the retail core to SE 48th and Hawthorne. McMenamins refurbished the vacant video store as the Bagdad Pub, a brew pub of conspicuous style which has pushed 37 th and Hawthorne one notch higher on the scale of style and conviviality.

The first half of 1992 saw a number of other changes that reinforce this higher class image. Two long-standing, small-scale businesses - Hardtimes East (an adult bookstore) and The East Portland Locksmith - moved from Hawthorne to more appropriate locations for their trade: the video store to NE Sandy Boulevard, the locksmith to SE Powell Boulevard. As noteworthy as the disappearance of Hardtimes East is its replacement by the second location of a Lake Oswego store selling bird houses and baths (Backyard Birdhouses).

Other recent changes to the business mix include Think Good Thoughts (cotton clothing), Tierra Madre (Latin American clothes), Bead Needs (loose beads and jewelry) where the Portland Eckankar Center once was, and Baba Roots (organic coffee) in what was a plant shop. Powell's Books took over the Beaver book store (Figures 9 and 10), and the Nearly New Shop, a long-time 


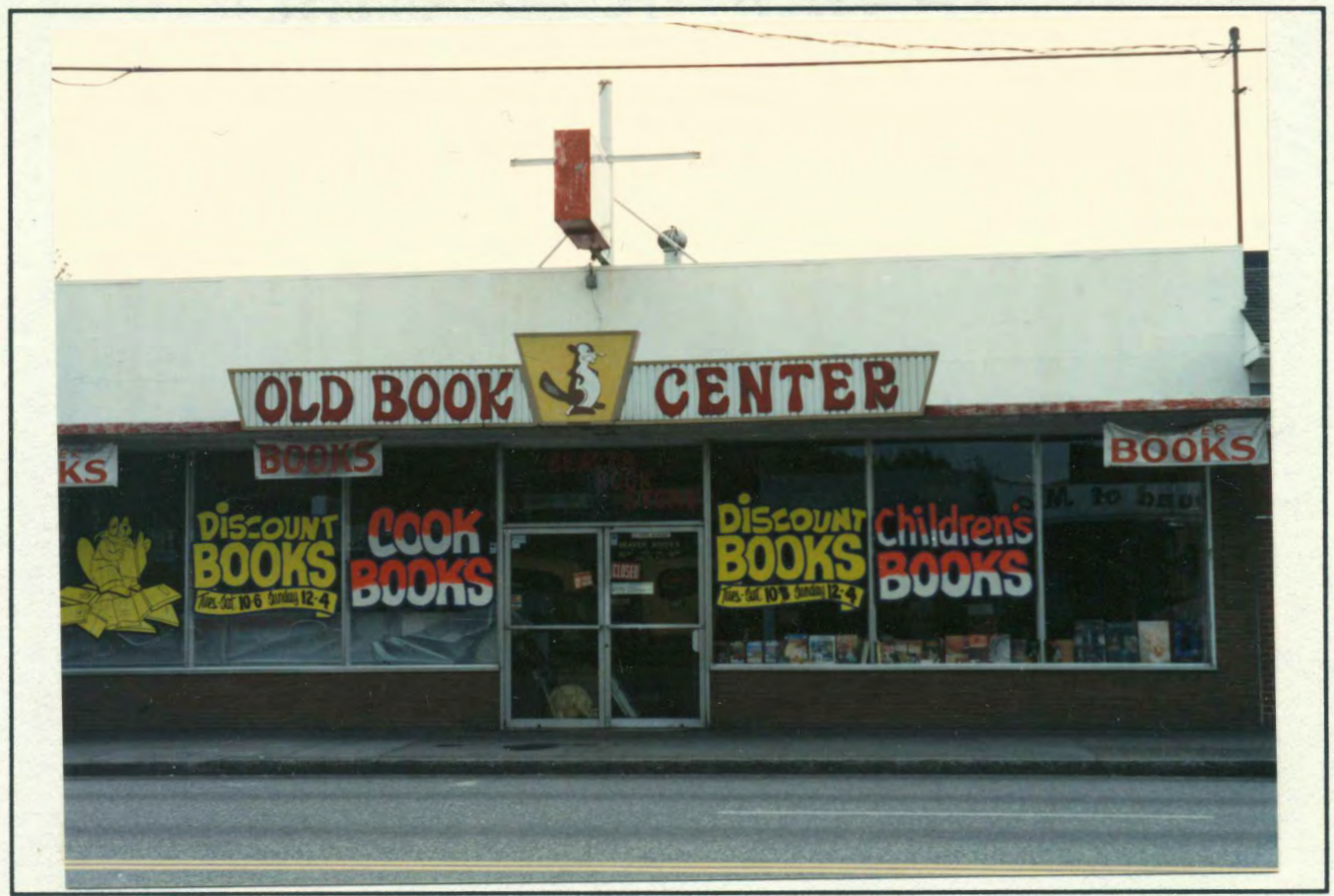

Figure 9. Beaver Books, 3747 SE Hawthorne Boulevard, in early 1992.

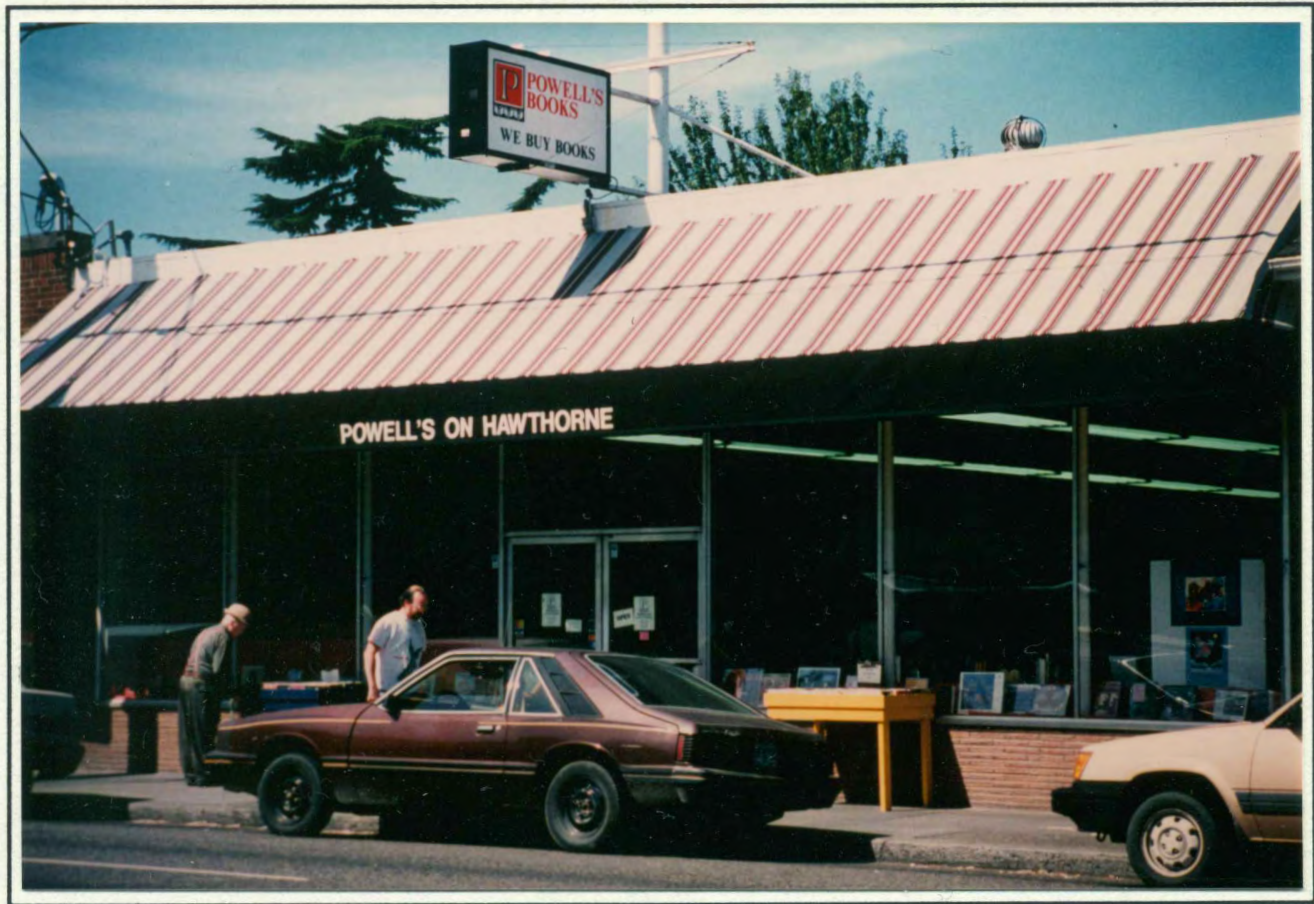

Figure 10. Powell's on Hawthorne, 3747 SE Hawthorne Boulevard, August 1992. 
Hawthorne business moved from the core (3508) to SE 18th and Hawthorne.

Some spaces have recently become vacant because a number of marginal businesses have gone out of businesses since the February 1992 closure of the Hawthorne Bridge. Routine maintenance needs for the bridge cut Hawthorne's main link with downtown for eight months (February to September 1992) and greatly reduced the traffic flow on the street. One restaurant owner mentioned an appreciable reduction in lunch-time patrons the day the bridge closed ${ }^{4}$.

Hawthorne's accessibility from downtown was temporarily reduced. While it is impossible to tie business failure directly to the closure of the Hawthorne Bridge, there has been an increased rate of turnover during the last few months. In addition to the businesses mentioned above, a bakery, a book shop, a catering service, and a clothes shop have left the street and have not yet been replaced. An entire building - four storefronts - stands vacant at 30th and Hawthorne.

\section{CLASSIFICATION}

It is clear that Hawthorne Boulevard is now a specialty shopping and restaurant area, and that trends identified in 1981 continue to influence the boulevard. However, to get an overall picture of the changing business mix and trace the evolution from a general service to a specialized retailing district requires grouping businesses to reflect important features of the Hawthorne mix. Cafe.

${ }^{4}$ Personal communication with Bruce Fishback, co-owner of Bread and Ink 
Classification facilitates comparisons between years and simplifies what is otherwise an unwieldy list of names and addresses (see Appendix B).

Businesses were grouped into categories that reflect Hawthorne's commercial specialties and illustrate the neighborhood to regional shift. Ten 'types' of businesses were thus identified: antiques; books; music; specialty; restaurants; gifts; clothing; household; professional services; and convenience. One further grouping - 'other' - is used for the unclassifiable and unidentifiable.

This grouping clarifies the business mix but hides the orientation of businesses which, for the purpose of this thesis, are as important as the types. A second level of classification thus considers the focus of businesses, covering only those businesses which fall into three specific categories described as 'yuppie,' 'PC/bohemian,' and 'resale:' these are the most striking cultural features of Hawthorne's business mix today. The first two confirm the dichotomous lifestyles visible on Hawthorne; the third illustrates the continued accessibility of Hawthorne to poorer sectors of society. ('Resale' includes all stores that sell second-hand goods, including clothes, books and records.)

Effective classification entails identifying businesses which no longer exist on the boulevard. Too much time has passed to establish the exact focus of all stores but some information can be gleaned from business names. Most types can be classified by their name alone and, occasionally, by references made to them in business association newsletters.

The clientele, or orientation, of departed ventures is impossible to 
ascertain, unless it is apparent in their name: for example, Peace (1986-88) and Epicurean Delights (1980) can be classified as 'PC/bohemian' and 'specialty' respectively without knowing their exact function. Accuracy of the annual classifications increases as the years progress because later years list businesses still on the boulevard. This is particularly true in the identification of business orientation. Despite some problems in classification, the figures at least indicate some general trends and confirm the dichotomous position of Hawthorne today.

Statistics resulting from this dual classification are shown in the tables below. Table I shows the number of each type of business on Hawthorne during the study period. Overall, the number of businesses has increased by $19 \%$ since 1980 with the biggest increases being in bookstores ( $75 \%$ increase), restaurants (80\%) and clothes shops (1000\%). This last figure comes from there being only one clothing store on Hawthorne in 1980 and eleven today.

While retail specialization is generally indicative of gentrification, this classification of Hawthorne splits specialties into their various forms. The 'specialty' category includes specialized functions which do not fit into any other category including, from today's list, The Graystone Gallery, Northwest Futon, The Bagdad Theatre and the Neon Art School. This, the least well-defined category, showed an increase from thirteen to nineteen during the study period, hardly significant given its random composition.

Two of the district's noted specialties showed no increase in numbers. There were three antique stores and nine music stores in 1980; there are the same 


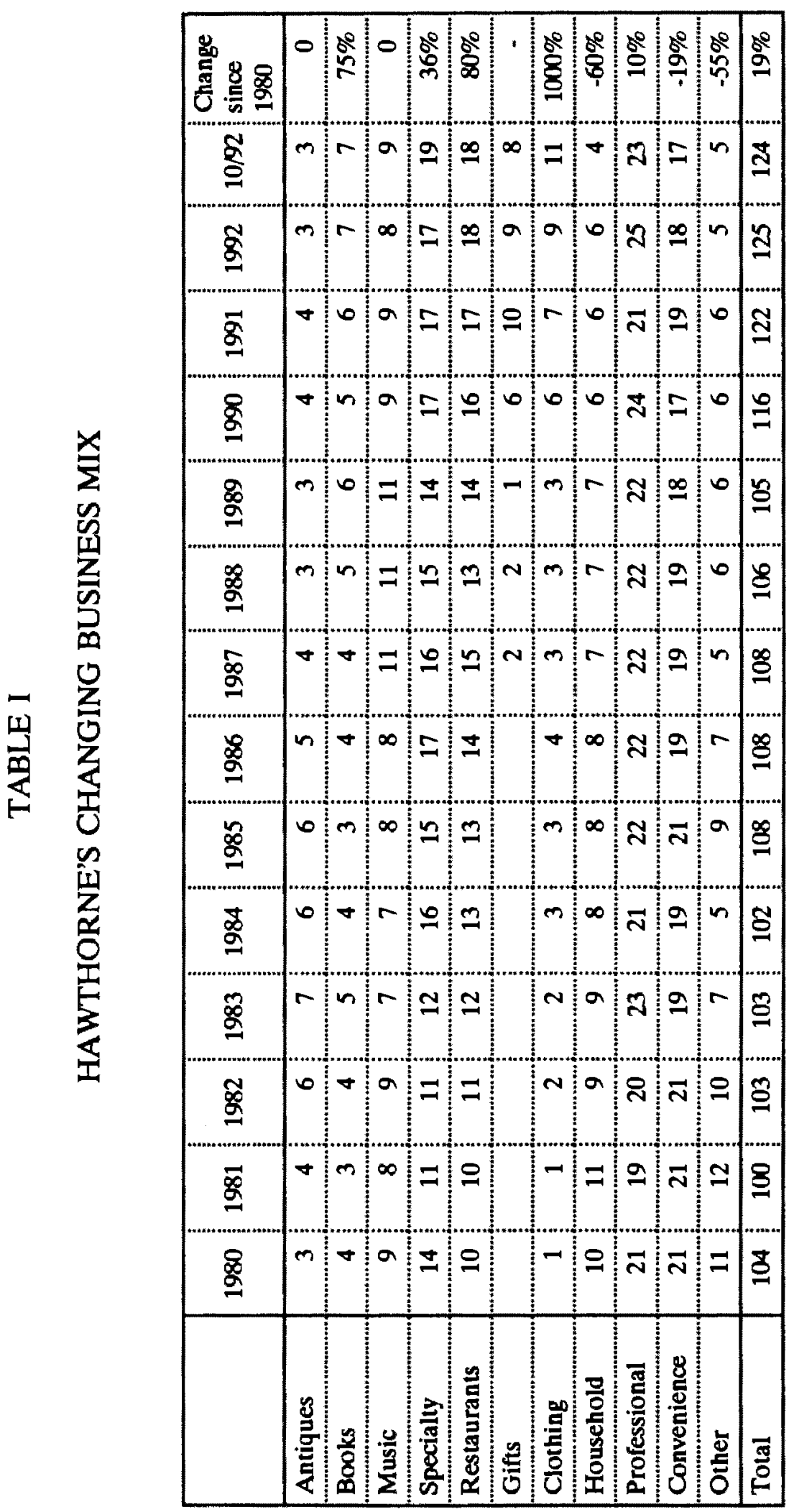


number of each today. Closer examination of the figures shows 'antiques' reaching a high of seven in 1983 , perhaps because antique shops require relatively low rents. During the first few years of revitalization they flourished but have since been priced out. The number of music stores has remained fairly constant, wavering from a low of seven to a high of eleven. A near doubling in the number of bookstores and restaurants is indicative of a more educated and wealthy clientele frequenting the boulevard. Both categories are on an upward trend and now form the basis of the popular image of Hawthorne more than do the antiques and music stores.

Specialized restaurants are a significant indicator of the transition to a regional focus but, more telling, is the increase in gift stores: there are eight today where there were none in 1980. An expanding market for gifts is evidence of the growing importance of recreation shopping and tourism on Hawthorne Boulevard, not because local people do not frequent these stores but because there is not a sufficient local market to support them.

Similarly, clothes shops depend on a larger market than exists in the immediate area. Table I shows that restaurants, gifts shops and clothing stores all underwent their biggest annual increase in 1990, the same year that the total number of businesses increased by its largest percentage in a single year. The increase in total businesses was made possible by the renovation of two buildings (mentioned above) which, together, provided eleven new retail locations. All of these were taken by specialty stores. The leap towards a regional focus for 
specialty goods in 1990 corresponds with the completion of revitalization and the transition to gentrification.

The influx of specialty stores is, however, only one half of the gentrification equation. Because the number of retail locations in a given district is finite (barring major construction), the arrival of new stores entails the departure of others: as low order goods move out, high order goods move in. Displacement of neighborhood stores is another indicator of a business mix tipping into gentrification.

Table I shows that the number of 'convenience' businesses (convenience stores, beauty salons, taverns, etc.) has fallen by just four, from twenty-one to seventeen, since 1980. This does not indicate a serious decline in the number of merchants serving the local population. But, when compared to the overall increase in the number of businesses 'convenience' has fallen from $20 \%$ of the total in 1980 to $14 \%$ today. Rather than being displaced, businesses serving the immediate neighborhood now comprise a smaller proportion of the total and, thus, contribute less to the street's image than they used to.

Businesses providing home-focused services (furniture finishing, carpet fitting, awning making, etc.) fell by $60 \%$, from ten to four, during the same period. This confirms the move away from service provision more than the move towards gentrification. However, because these services were all replaced by retailing, their demise, indirectly, paved the way for gentrification.

The second group of services, 'professional services' (banks, realtors, 
accountants, travel agents, etc.), has remained fairly constant in number. These serve a market area somewhere between the neighborhood and regional levels and, as yet, have not fallen victim to increasing rents. However, few professional services occupy storefronts in the core: most are on second floors, in side streets, or west of 34 th Street. These non-retail uses continuing to flourish on an increasingly retail-oriented street, shows that the Hawthorne business district still serves a practical function. It has a long way to go before it becomes just a festival marketplace, catering purely to tourists and recreation shoppers.

The figures presented in Table I show definite trends towards specialty goods, towards regional businesses, and towards higher class stores. They could allude to any street undergoing gentrification yet, taken alone, these data do not tell the whole story. Hawthorne has followed a different tack from that of comparable streets and the economic elitism and conspicuous consumption usually connected with gentrification have been kept to minimum.

Table II confirms the dichotomous nature of Hawthorne's revitalization. While high class 'yuppie' businesses increased ten-fold (confirming the thesis of gentrification), they do not reflect the only cultural shifts taking place.

Environmentally aware 'PC/bohemian' businesses also became more apparent (portraying the possibilities of gentrification by those other than an economic and cultural elite). Unidentifiable in the 1980 listings, they are now a significant presence. 
This year has seen a dramatic increase in the number of PC stores on Hawthorne. Almost every business that has opened its doors in the past six months reinforced the district's bohemian image. Bead Needs, Tara (Himalayan crafts), Baba Roots Organic Cafe and Tierra Madre (Latin American clothes and crafts) are all recent additions to the business mix.

\section{TABLE II}

\section{CHANGES IN BUSINESS ORIENTATION SINCE 1980}

\begin{tabular}{|c|c|c|c|}
\hline & Yuppie & PC/bohemia & Resale \\
\hline 1980 & 2 & 0 & 7 \\
\hline 1981 & 1 & 0 & 7 \\
\hline 1982 & 2 & 0 & 9 \\
\hline 1983 & 2 & 1 & 10 \\
\hline 1984 & 5 & 3 & 10 \\
\hline 1985 & 6 & 3 & 8 \\
\hline 1986 & 9 & 4 & 9 \\
\hline 1987 & 11 & 5 & 9 \\
\hline 1988 & 11 & 7 & 10 \\
\hline 1989 & 12 & 6 & 12 \\
\hline 1990 & 15 & 9 & 9 \\
\hline 1991 & 18 & 11 & 12 \\
\hline 1992 & 20 & 12 & 13 \\
\hline $10 / 92$ & 19 & 17 & 11 \\
\hline
\end{tabular}

The dominance of PC businesses is reinforced by the resale stores which, by the very nature of their merchandise, discourage consumption and encourage recycling. Resale businesses reached a peak of seventeen in 1983, coinciding with the greatest number of antique stores during the study period. The number now stands at eleven, apparently dispelling any claims of elitism associated with 


\title{
Discover Hawthome's RESAIE BOULI/ARD
}

\author{
Hawthome \\ Bridge $\Rightarrow$

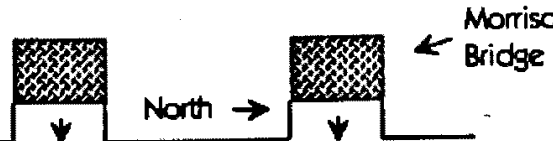 \\ CONSIGNMENTS \\ WELCOME \\ AT ALL \\ LOCATIONS!

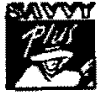 \\ Sayy Plus \\ - size 14+ - 4 \\ 3904 SE Hawthome

\section{1-7116} \\ What Goes Around \\ 3206 SE Howthorne \\ 232-1637

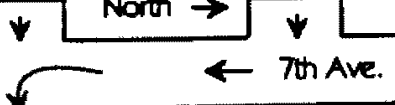 \\ Ihree Times A Lady \\ | \\ 1493 SE Howthome \\ 234-5517

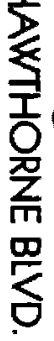 \\ 2 \\ Aly Paradise "Resale" \\ 51 Boutque \\ 1499 SE Hawthome \\ 236-2901 \\ 3 New Wave Resale

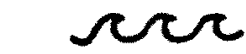 \\ 1785 SE Hawthome \\ 235-4565

\section{STROLL BY} \\ AND \\ SAVE! \\ Specializing in: \\ - CHILDRENSCLOTHING $(1,3)$ - WOMENS $(1,2,3,4,5)$ \\ - VINTAGE $(2,3,5)$ \\ - MENS $(2,3)$ \\ - LOCAL DESIGNERS/FUNKY 60's \& 70's (2)
}

Figure 11. Advertisement showing most of Hawthorne's resale clothing stores. (From local newspaper.) 
gentrification. Hawthorne has a continuing reputation as a source of second-hand goods and proudly advertises the fact (Figure 11). Most of the stores classified as 'resale' in the core sell either books or records. There are only three secondhand clothing stores in the study area, all selling good quality items. The one remaining thrift store on Hawthorne has recently moved out of the core to SE 18th and Hawthorne.

While the most significant changes have taken place in this core area between SE 28th and SE 39th, other sections of Hawthorne have been touched by the same process. The appearance of new businesses west of SE 28th and east of SE 39th which correspond to the boulevard's revitalized image bear witness to the spread of gentrification. However, in spite of the beginnings of gentrification outside the study area, the composition of the business district differs between the three parts of Hawthorne Boulevard and its extremities, both east and west of the central section, maintain their own characters.

The top of Hawthorne, between SE 39th and SE 50th, remains a provider of neighborhood services. There is a gas station, a couple of car repair shops, a number of hairdressers and convenience stores. The 'Hawthorne-style' stores are towards the western end, closest to SE 39th. The Culture Shock Gallery (Native American art), The Third Eye ('Grateful Dead Headquarters'), and Hey Joe (used books and records) are all within two blocks of this major intersection. The high class mainstay of the upper end of Hawthorne Boulevard (east of 39th) is JaCiva's Chocolatier, which sells cakes and chocolates hand-made on the premises. 
Last year saw the opening of It's My Pleasure at 4526 SE Hawthorne, a 'feminist novelty shop' which has multiple roles as an art gallery, a gift shop, and Oregon's only sex toy store for women! The store's owner notes that Hawthorne was the obvious choice for the business because it is close to downtown, and the surrounding area contains a high proportion of women ${ }^{5}$. She notes the clustering of women-focused stores on Hawthorne and the cooperation between women store owners. Stores such as It's My Pleasure, In Her Image and Ladd's Editions are not in competition with one another, but rather, benefit from each other's customers. She was able to open a store on Hawthorne because rents on the eastern end of the street are still low. Revitalization is only just starting to spread east of 39th.

Gentrification, however, is beginning to spread to a secondary node focused on SE 18th. While businesses at the eastern end of the boulevard, with a few noticeable exceptions, have retained their neighborhood focus, the western end is evolving into a second node of gentrification. Recent months have seen the arrival of a bagel bakery (Big Bear Bagels) and an art gallery (Norm's Originals), and the transformation of The Rocking Horse Restaurant into Le Canelet, a French bistro. Older businesses include a feminist bookstore (Ladd's Editions) and another McMenamin's Pub (The Barleymill).

Revitalization in these areas peripheral to the Hawthorne district is helping reinforce the commercial strength of the street as a whole. Stores and restaurants

${ }^{5}$ Personal communication with Holly Mulcahey, owner of It's My Pleasure. 
serving an extra-local market dominate the business mix today along the whole length of the street but, particularly, between SE 28th and 39th Streets.

Hawthorne is a very different place than it was in 1980 when specializations were beginning to appear but were insignificant when compared to the total number of businesses. The success of early enterprises provided opportunities for further specialization and expansion of the market area which continues to the present day. Ironically it is the increased 'regionalization' of Hawthorne businesses, and the consequent increase in traffic, that paved the way for the Hawthorne's revitalization and its subsequent re-pedestrianization.

The regional focus and increased commercial vigor of Hawthorne are clear. Yet knowing the names of businesses and the break-down of the business mix does not adequately convey what these changes have meant for the district. Hawthorne's image - how it is perceived by its patrons - comes not only from the individual stores and restaurants but, also, from their appearance, character, and their relationship to one another and to the built environment. The following chapter takes these ideas and expands the description of Hawthorne offered here. 


\section{CHAPTER III}

\section{HAWTHORNE'S IMAGE}

The commercial transition since 1980 influenced Hawthorne's character more than just changing the business mix. As well as redefining the district's niche in Portland's retail environment, the influx of specialized stores and restaurants altered its sense of place: Hawthorne's commercial evolution entailed a simultaneous cultural evolution. The influx of new stores led not only to an upgraded business mix but also to improvements in the built environment and to a new clientele frequenting the district.

This chapter considers how revitalization has affected Hawthorne's image. As quoted earlier, Hawthorne is predominantly "pro baked goods and anti Contra:" its overriding character remains one of relaxed political correctness. Yet this description simplifies a district which is many things to many people: a neighborhood shopping street, a collection of good restaurants, a hippie enclave, a yuppie street, a lesbian hang-out, and a great place to buy used books and good coffee. In fact, Hawthorne is all these and more.

The success of Hawthorne stems from its image and how it is perceived by its patrons. Factors contributing to this image can be split into those inherent to the district (intrinsic features), and those which have been created specifically to create an image (contrived features). Into the former category fall the buildings, 
the stores and the people of Hawthorne Boulevard: its landscape. The latter consists of promotional activities such as street fairs and organized advertising. Hawthorne's image is based on these two facets in combination. This chapter addresses them separately, looking first at intrinsic, then at contrived, features.

\section{THE HAWTHORNE LANDSCAPE}

Hawthorne's physical environment is an intrinsic feature that remains constant over time. The edges of the study area - SE 28th and 39th Streets - are closely tied to Hawthorne's image. They coincide with visual breaks on the boulevard and roughly bound the pedestrian-focused area. SE 28th is on the crest of a low hill - a natural break in the commercial strip. To the west one can see downtown Portland, about a mile away; to the east sits Mount Tabor, a treestrewn hill that truncates Hawthorne Boulevard and provides an impressive natural backdrop.

Safeway is between 28 th and 29 th - one of the two block-sized buildings on the street. At the other end of the study area, SE 39th, sits its counterpart, Fred Meyer. Occupying a whole block, this single story, windowless building turns a blank face to the street. These two stores are not really part of the district for they have nothing in common with the character of the stores which lie between them. Rather than being the edges of the district they signify the beginnings of Hawthorne outside the study area. They are included simply as useful break points. 
The study area stops at SE 39th because the intersection of two major streets - SE 39th and Hawthorne - shifts the commercial focus towards the automobile. High traffic volume is best served by larger buildings and signs designed to catch the eye of the speeding motorist, and these dominate this corner. Along with Fred Meyer's 'one stop shopping,' several banks and a Jiffy Lube congregate on 39th and Hawthorne. Although commercial uses on the boulevard extend beyond 39th, this intersection is a major interruption to the character of the boulevard and effectively marks the eastern edge of pedestrianfocused Hawthorne.

Between 28th and 39th Streets lies the straight sweep of Hawthorne Boulevard. Approaching the district from downtown, a gentle slope draws the eye to the Hawthorne district and the cluster of buildings at the bottom. The break of slope at 34th Street is where the concentration of buildings begins and marks the edge of Hawthorne's four block core (from SE 34th to SE 38th). Outside of these four blocks the buildings are not connected to one another, either physically or architecturally, and the atmosphere of the district peters out.

This same section of the boulevard breaks with the regular street pattern. Streets crossing Hawthorne do not meet the boulevard at symmetrical crossroads but are slightly misaligned. Such irregularities in the street pattern add interest to the built environment because approaching from a side street affords a view of storefronts rather than a continuation of the road. This adaptation of the grid, an element of which most shoppers are probably unaware, adds character to the area. 
These complicated intersections also hinder the smooth flow of traffic on a street which is always busy. Hawthorne has two lanes of traffic in each direction with parking on both sides of the street. Buses pass by every few minutes, further disrupting the traffic. In September 1992, the frequency of buses on Hawthorne was doubled to one every eight minutes (Southeast Examiner, October 1992), making it the best served bus route in the metropolitan area. In spite of this, businesses retain a pedestrian focus and the district as a whole is 'pedestrian friendly.' In fact, congestion can be seen as a positive force because it heightens the sense of an active shopping area.

Hawthorne's architecture consists largely of one- and two-story brick buildings with apartments and offices on upper floors. There are several apartment buildings and single-family houses. Few street-car era buildings remain: out of a total of over seventy buildings in the study area, only five are designated as historic. These are the Douglas Building (3525-3541); the Henry Sensel Building (3500-3508); the Charles Piper Building (3556-3562); the Bagdad Theatre (3701); and the Sunnyside Masonic Temple (3862).

Almost all the buildings in the core were renovated during the 1980s and, excluding the construction of one fourplex on 34th and Hawthorne, the most conspicuous improvement to buildings has been the addition of awnings to a large number of the storefronts. Awnings serve a number of purposes of which decoration is the most obvious. Matching awnings give an identity to buildings which contain several businesses, and create a conspicuous location for a store's 
name. Awnings also define a space that is clearly 'pedestrian' enhancing the ambiance for foot traffic on an auto-dominated street.

Recent months have seen a proliferation of awnings on Hawthorne with the most recent additions being on Sorel Vintages (antiques) and Powell's on Hawthorne (books), both on the north side of the 3700 block. The popularity of this form of decoration may be a reaction to the absence of trees on the street. What little shade exists comes solely from awnings above storefronts. (There are many more awnings on the north side of Hawthorne than on the south.) Indeed, Hawthorne Boulevard is a misnomer for the boulevard has little greenery: just a few planters on 37th, north of Hawthorne, and some small trees in the parking lots of Arctic Circle and the Hawthorne Health Clinic.

Another form of decoration, unplanned and, perhaps, more striking than the awnings, are the brightly colored flyers which cover the wooden utility poles advertising public meetings and concerts (Figure 12). Their presence is a distinct component of the Hawthorne image although they are regarded as litter by HBBA. Removing them would rob the pedestrian environment of an unusual element of color and interest. Occasionally a pole is stripped of its posters leaving many years' worth of rusty staples which look far worse than even the most erratically decorated pole. Clusters of posters give the street an air of unruliness which forms a large part of Hawthorne's appeal.

The informal mingling of this spontaneous decoration with the colorcoordinated awnings constitutes an attractive backdrop for the stores which are 
the cornerstone of the district's character. Indeed, this distinctive juxtaposition extends into Hawthorne's stores: the stylish and the old-fashioned, the cluttered and the spartan, are neighbors on the boulevard.

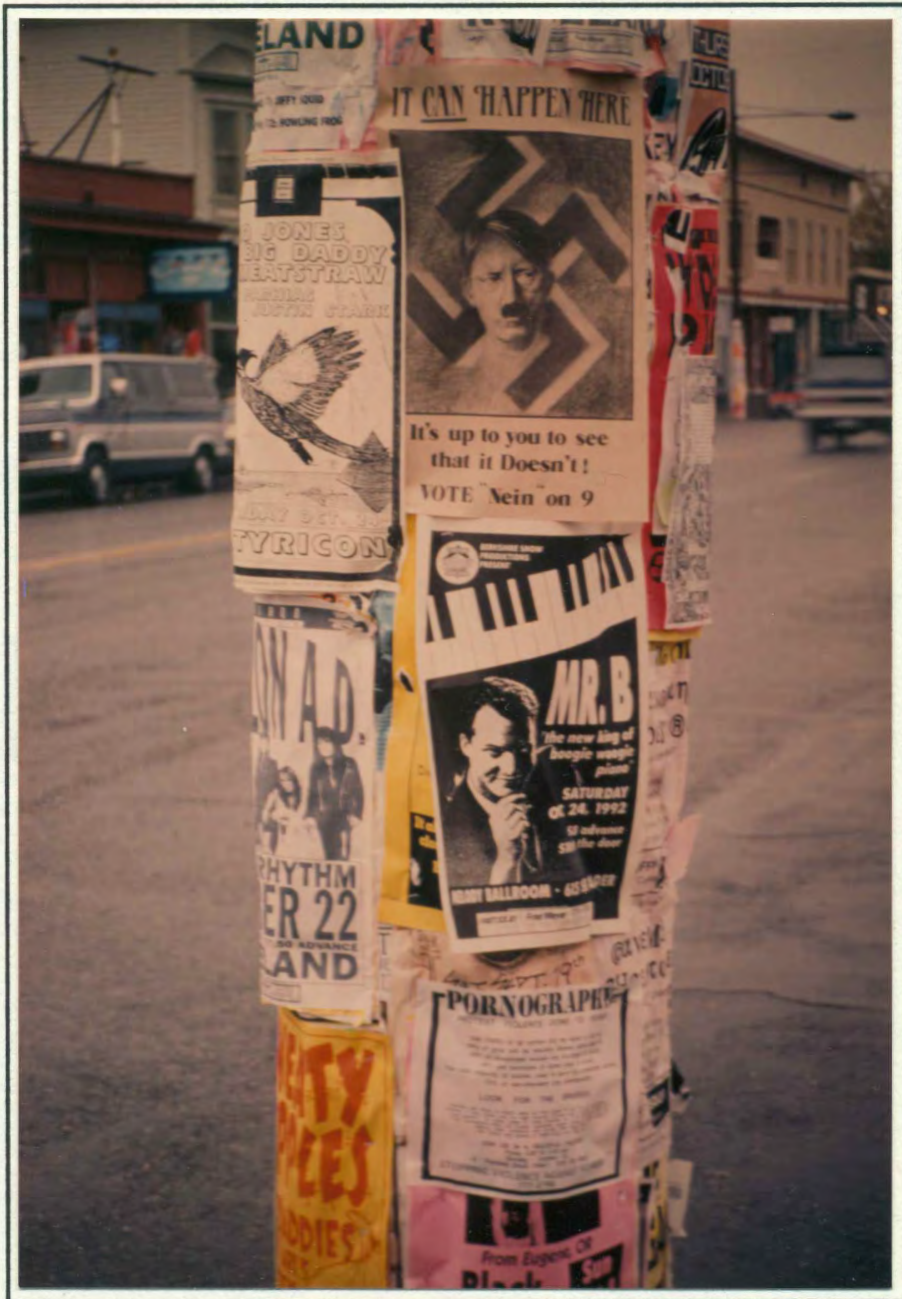

Figure 12. Many of Hawthorne's utility poles are covered with flyers. 


\section{STORES}

The most dramatic alteration to Hawthorne's image has come from the new mix of stores and restaurants. These changes in the business mix have, more than anything else, changed how the district is perceived. I consider stores to be intrinsic elements of Hawthorne's image because their arrival is largely unplanned and their character depends on the actions of individuals rather than an organized group.

The combination of stores is paralleled by the people on the street and, as such, the Hawthorne renaissance transformed not only the boulevard's business mix and physical appearance but also redefined its culture. The combination of stores and the diverse subgroups these attract create Hawthorne's dichotomous image as both a quasi-hippie hangout and a gentrifying retail and restaurant district. Although the latter description dominates the business mix, the former more accurately characterizes the area's image. The PC atmosphere that pervades Hawthorne stems from the combination of several related groups who see the boulevard as home: the counter-culture; the environmentally aware; and politically active women (all of these would fall under 'PC/bohemian' in Chapter II).

The cultural aspect of Hawthorne's image - who it appeals to - is best considered in relation to the stores. Clearly no stores caters to just one 'type' of person if, indeed, people can be accurately grouped into types. Yet there are several businesses on Hawthorne Boulevard which encapsulate the district's image: 
stores and restaurants which immediately come to mind when Hawthorne is mentioned. A few exemplary locations thus form the basis of this account.

Primary among these is the intersection of SE 37th and Hawthome - the focal point of the district and the quintessence of the Hawthorne Renaissance. On the southeast corner is the alhambraic Bagdad Theatre, the tallest and most striking building on the boulevard (Figure 13). The Bagdad dominates all views of Hawthorne: its minarets, arches and angular tiled roof tower above its neighbors, and its neon sign is visible for the entire length of the district. It is a whimsical anomaly from the 1920 s that, in spite of its incongruity, provides a focus for a street of architectural fragments. Having the most dramatic structure at the prime intersection in the district reinforces 37 th Street's centrality, creating a memorable impression of Hawthorne. If struck by nothing else, visitors remember the Bagdad Theatre.

This building dominates the street socially as well as physically. It is the focus of night-time activity on the boulevard. Recently bought and remodelled by the McMenamin brothers, the Moorish megalith follows the successful pattern of their Mission Theater in Northwest Portland. Movies, shown some months after the original release, are just one dollar. Combining a low entrance price with popular micro-brewed beers draws a mixed crowd from all over town.

Far from the ten-screen movie theaters of the malls, the Bagdad retains the qualities of an old-fashioned, single screen cinema, combined with an unusual Middle-Eastern motif. Next door, the even newer Bagdad Pub teems with the 


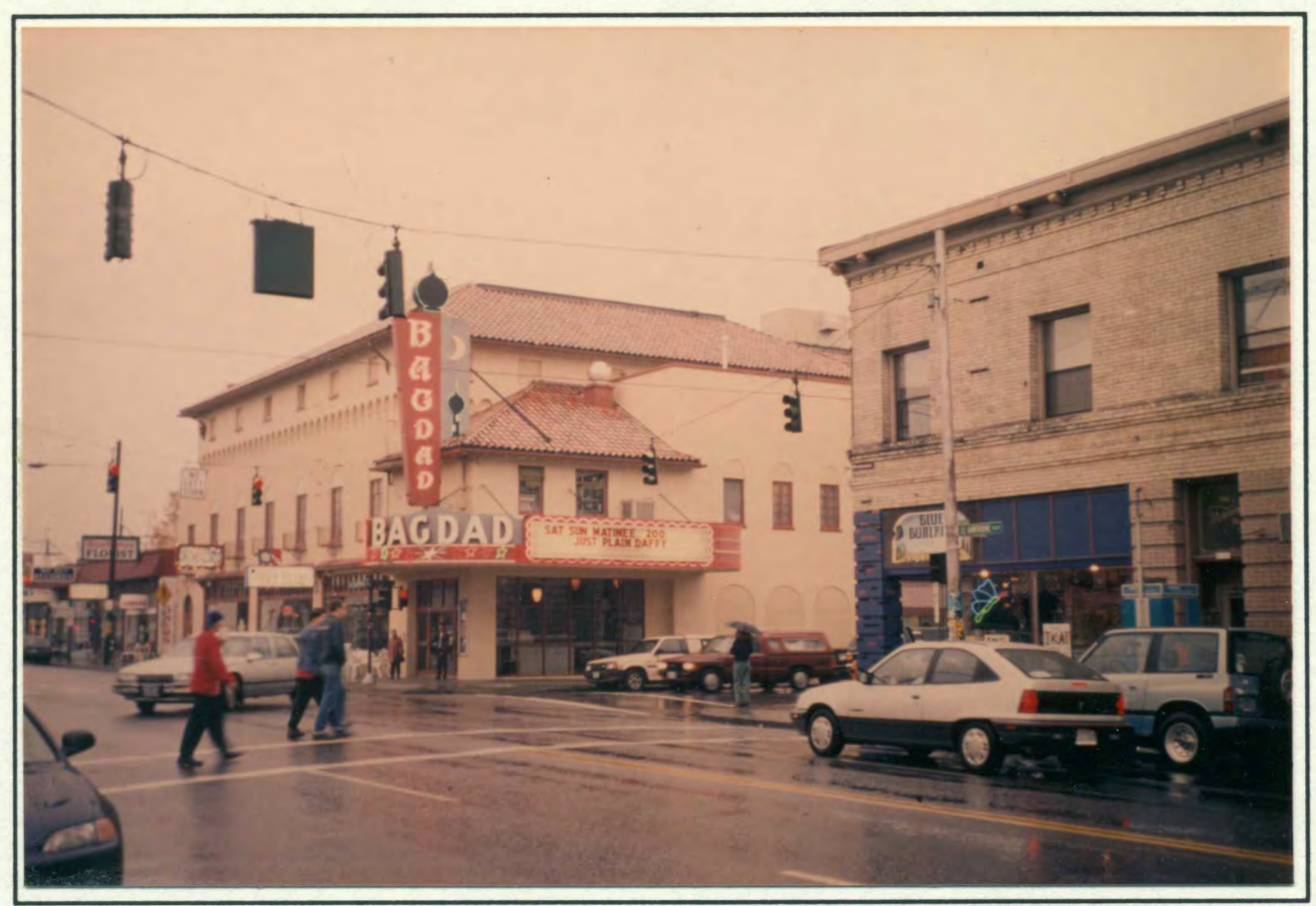

Figure 13. The Bagdad Theatre.

young and the well-dressed. In keeping with the Arabian Nights' theme, handpainted murals bedeck the interior with scenes of dancers and mythological creatures. Its bright lighting and store-front windows produce a festival restaurant atmosphere, 'pseudo-casbah,' out-of-step with the neighborhood pub feel of other McMenamin's joints. Oversized windows looking in on pastel walls and decorated furniture create the impression that one comes here to hang out and be seen: chairs and tables on the sidewalk add to the pastime of watching and being watched.

Starbucks, the Seattle-based fast coffee chain, is on the opposite (northwest) side of the intersection (Figure 14). This omnipresent superpower of the coffee world fulfills much of the city's need for caffeine, with numerous 


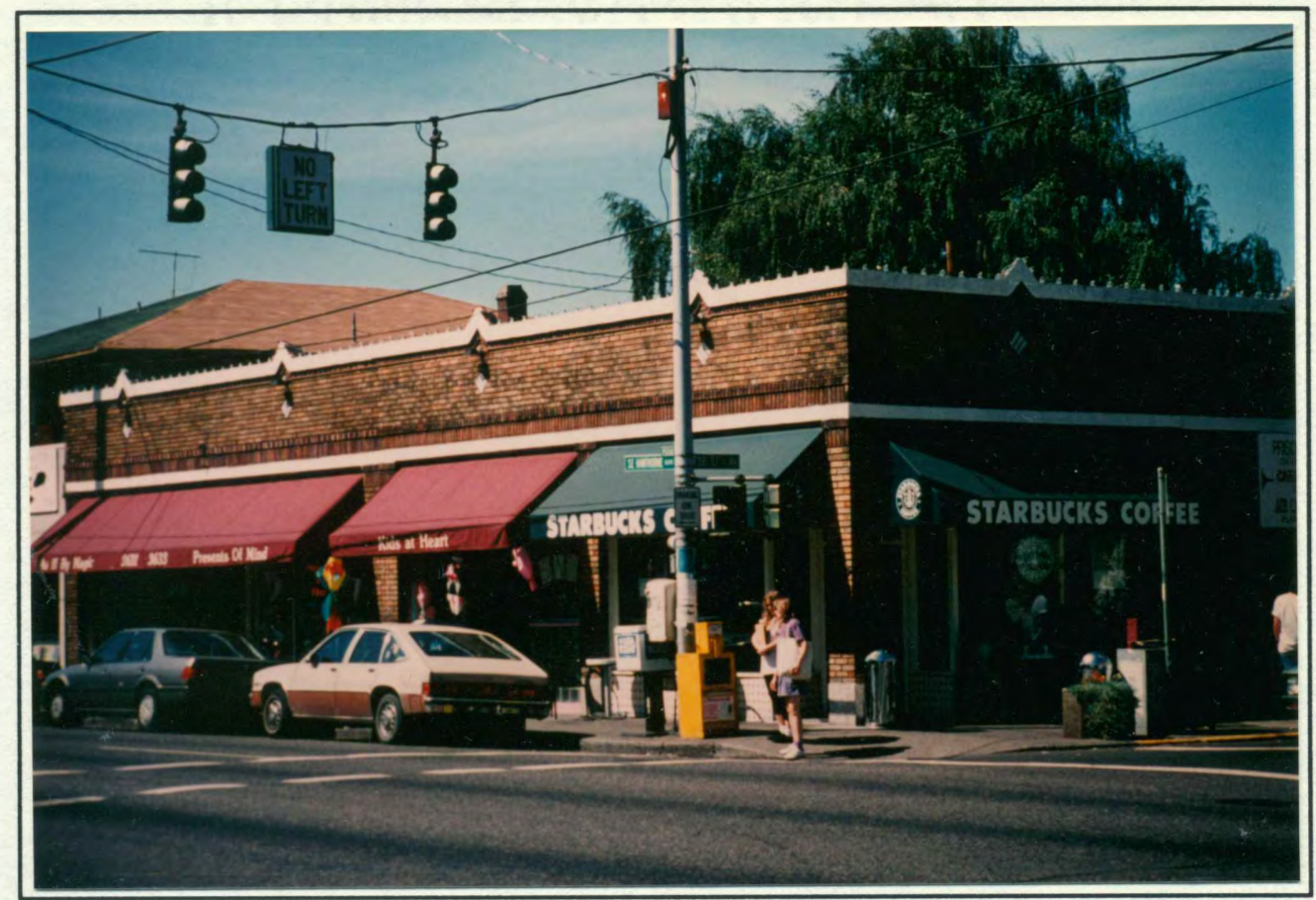

Figure 14. Starbucks Coffee.

branches in the Portland metro area. Its classy reputation is reinforced by a standardized, slick image which combines a distinct Northwest green logo, with a black and silver trim that seems to epitomize yuppie style. Once a luxury of the image-conscious, espresso and biscotti are trickling-down; in a city where good coffee is ubiquitous, Starbucks is the leading player.

There are so many Starbucks outlets that its presence on any street may signify nothing more than proximity to a large, coffee-buying clientele. Yet almost all of the innumerable branches in the city are in the major shopping districts (downtown, Lloyd Center, NW 23rd, NE Broadway and SE Sellwood, among others). Starbucks graces every successful retail center in Portland; its coming to Hawthorne in 1991 indicates that the boulevard had made it into the big league. 
No longer a small-scale, neighborhood-based strip, Hawthorne had established its reputation as one of the most prominent retail areas of Portland.

Customers at Starbucks indulge in the sidewalk cafe atmosphere across 37th Street from customers at the Oasis Cafe who also dine on the street (Figure 15). The Oasis Cafe customers are a more mixed, pizza-eating crowd in a 1950 s place that seems to have woken up in the ' 60 s. Compared to both the Bagdad and Starbucks, there are more shaved heads, more Birkenstocks, and more tiedyed and 'alternative' clothes among both staff and customers. One corner is littered with unruly piles of free newspapers and flyers advertising local bands and services. The art on the walls is less prosaic than the Bagdad Pub - not that Arabian Nights are prosaic, but Oasis Cafe art is less predictable, potentially more offensive, ever-changing, and is for sale. Homeless folks wander in and out, often scrounging scraps from those eating outside.

The Oasis Cafe fills a late-night need not met by its neighbors: its pizza is cheaper than the Bagdad's, its coffee is cheaper than Starbucks', and it sells desserts. The cafe epitomizes the diversity and laid-back atmosphere on which Hawthorne prides itself: anyone finding themselves on Hawthorne after dark seems to wander into the aptly-named Oasis. It is the late-night counter-culture center of the street.

The fourth (southwest) corner of 37 th and Hawthorne balances the consumption/conservation equation of this pivotal intersection (Figure 16). A clothing store (Blue Butterfly) sells brightly patterned articles from around 


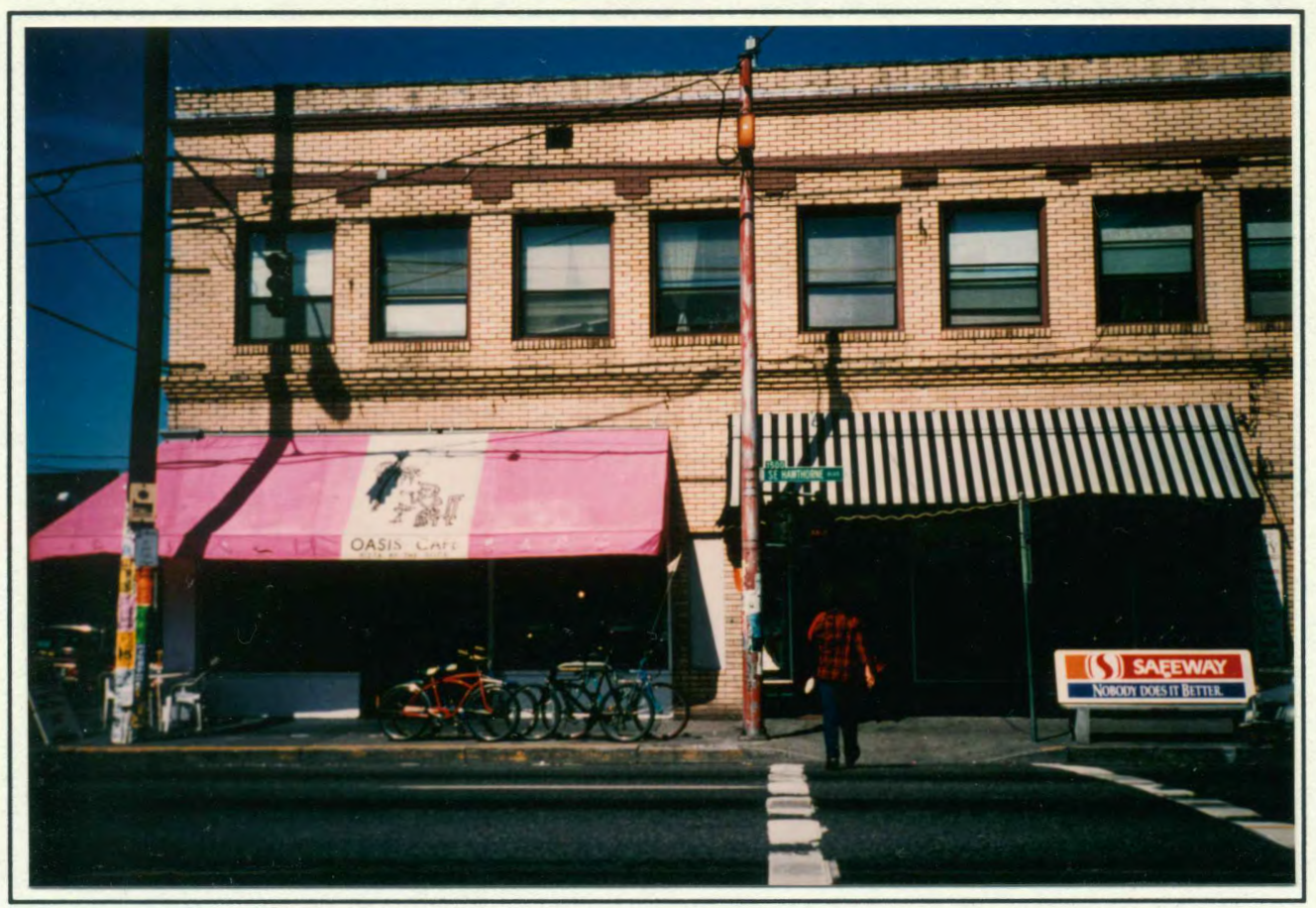

Figure 15. Oasis Cafe.

the world. Its windows - set into a bright blue tiled storefront - are full of African carvings, silver jewelry and dramatic pieces of clothing. At night, a neon butterfly glows in a side window. Inside, the store is dimly lit and thick with the smell of incense. Shirts hang on the walls and circular racks of clothes fill the whole store. This is the height of PC consumption: casual clothes made in the under-developed countries to give the wearer a world-conscious look.

Many of Hawthorne's other clothes shops correspond to the bohemian aspect of the district. Think Good Thoughts sells tie-dyed cotton clothing and political buttons; Visible Impact, What Goes Around?, and Savvy Plus deal in secondhand clothes; Tierra Madre and Tara (next door to one another) both sell ethnic clothing and crafts. The list of conspicuously PC/bohemian businesses is 
rounded out by Baba Roots Organic Cafe and World Neighbors.

The other side of the Hawthorne's cultural equation is represented by stores such as Carolyn Locke, designer clothes (with another store on NW 23rd); Bread and Ink, Hawthorne's most expensive restaurant; and the Pastaworks, Salumeria di Carlo, Powell's Books for Cooks combination, "the most popular address in the Hawthorne district's good-food ghetto" (Irving 1990, p. 155).

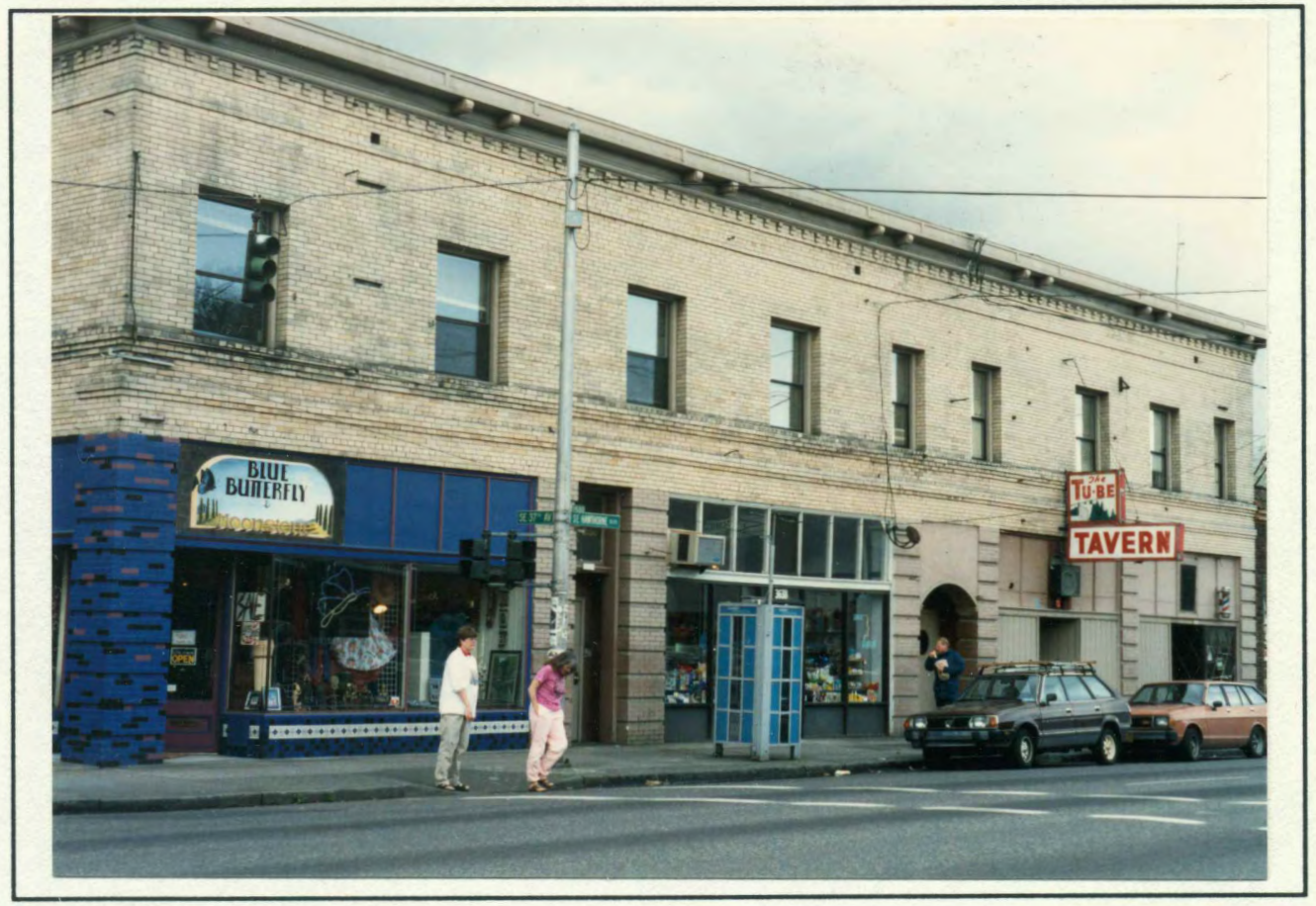

Figure 16. Blue Butterfly. 


\section{THE FEMINIST IMAGE}

One less obvious aspect of Hawthorne's image is the strong feminist feeling on the street, and the district's support of, and patronage by, the lesbian community. This is an unusual orientation for a retail district, one which has not been addressed in academic work. The female factor on Hawthorne goes far beyond simply being a reflection of shopping as a recreational activity for women rather than men. Women are the dominant shoppers in all retail districts, but on Hawthorne the notable presence of politically active feminists gives a twist to the street's image. Its reputation has attracted women-focused stores, contributing to a process I call the feminization of Hawthorne. (Although lesbian activism and the women's movement are not the same thing, there is a large enough overlap to consider them together (see Adler and Brenner 1992; Jackson 1989).)

The increasing feminist orientation of Hawthorne is almost hidden from the casual observer: In Her Image gallery is the only business in the study area which overtly puts its emphasis on women. Yet the clothes shops sell only women's clothes; Escential Lotions has a predominantly female clientele; and Crone Magic describes itself as "a cauldron of goddess lore, secrets. mysteries and treasures." El Mundo for Women, a natural fiber clothing store at 3556 SE Hawthorne, is complemented, on NW 23rd, by El Mundo for Men.

A less obvious example is The Cup and Saucer Cafe which serves as a gathering place for the lesbian community. The Cup and Saucer is one of Hawthorne's most popular eating places. On weekend mornings the line of 
people waiting for a table often stretches out onto the street. Among its diverse clientele are a large number of lesbians who regularly outnumber everyone else in the restaurant. Its reputation is reinforced, and its clientele confirmed, by the numerous flyers pinned up outside: Lesbian Pride Dance, The Other Queen's Ball. Inside, the bare wooden floor and pale blue walls are almost institutional in their austerity. Tables are close together, maybe a little too close. Five large, colorful paintings on one wall are the only decoration. This restaurant exudes political correctness - there is no ice in the water, no judgements made about clients, and no tolerance of bigotry.

The lesbian presence on Hawthorne is not limited to the few places which actively encourage their patronage: they form a significant part of the customer base. One anecdotal story tells of a lesbian couple being asked to moderate their behavior during a romantic dinner at a Hawthorne restaurant. The event caused a stir in the lesbian community including a threatened boycott of the restaurant. Pointing out that lesbians spend a good deal of money at Hawthorne businesses and expect better treatment, a apology was solicited from the restaurant. The lesbian community clearly regards Hawthorne as its street.

\section{Advertisements}

The association between Hawthorne and the lesbian community is confirmed by the regular placement of advertisements by Hawthorne merchants in Portland's gay newspapers Just Out and The Lavender Network, and a new publication the Feminist Broadcast Quarterly $(F B Q)$. In the most recent issue of 
$F B Q$ there is a whole page of advertising by Hawthorne merchants (Figure 17). These businesses are less readily associated with the feminist aspects of Hawthorne, yet their backing of $F B Q$ shows both support for the publication and an awareness of their markets. Similarly, many of Hawthorne's conspicuously PC stores run adverts which reflect their environmental or political concerns. Figure 18 illustrates the three sides of Hawthorne's image: the environmentally conscious, the bohemian, and the feminist.

Advertisements found on Hawthorne are as telling as those that advertise Hawthorne. In addition to posters on utility poles, there are flyers in many store windows which verify the merchants views on various issues. Most common are notices supporting the local Anti-Bigotry Coalition or stating "Degrading ethnic racial or sexist remarks not acceptable in this establishment." Opposition to Ballot Measure 9, which aims to rule homosexuality as 'abnormal,' in the November 1992 election, is very apparent on the street. "No On 9" posters and buttons are everywhere.

\section{ORGANIZED PROMOTION}

Advertisements continually create and reinforce an image of Hawthorne in people's minds (see Mills 1988; Lew 1983). This image is a composite picture produced by numerous merchants choosing individual advertising strategies. Even joint advertising ventures come from individuals who, having defined their own niche, want to be part of a larger whole. 
Page 14

Hawthorne Merchants SupportThe Feminist Broadcast Quarterly!
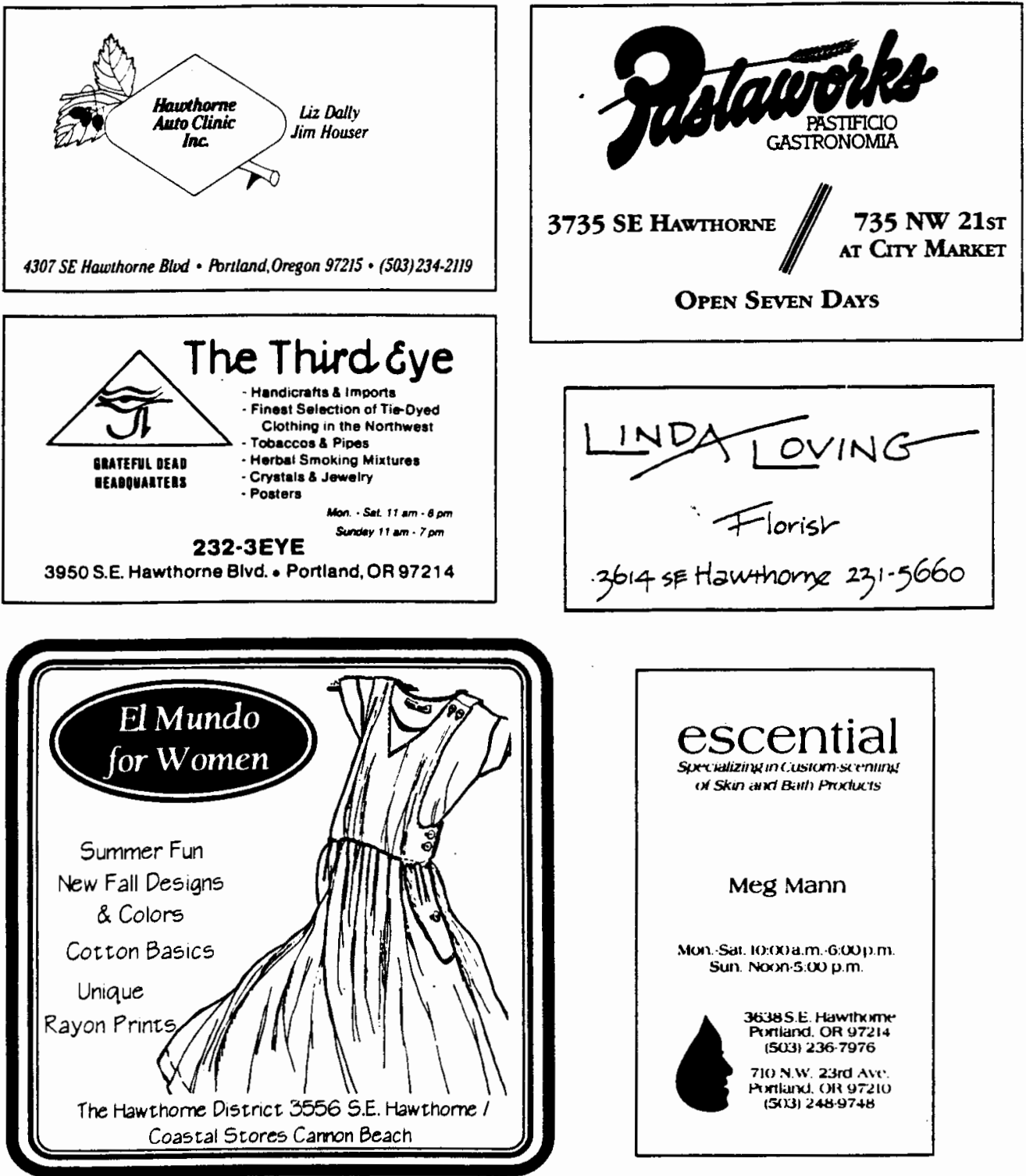

The Feminist Broadcast Quarterly is made possible thanks to the financial support of the businesses listed here and elsewhere throughout the magazine. Let's keep our allies healthy and patronize these businesses which support women's rights. And tell them vou sat' their ad in FBQ!

Figure 17. A page from the Feminist Broadcast Quarterly, September 1992. 


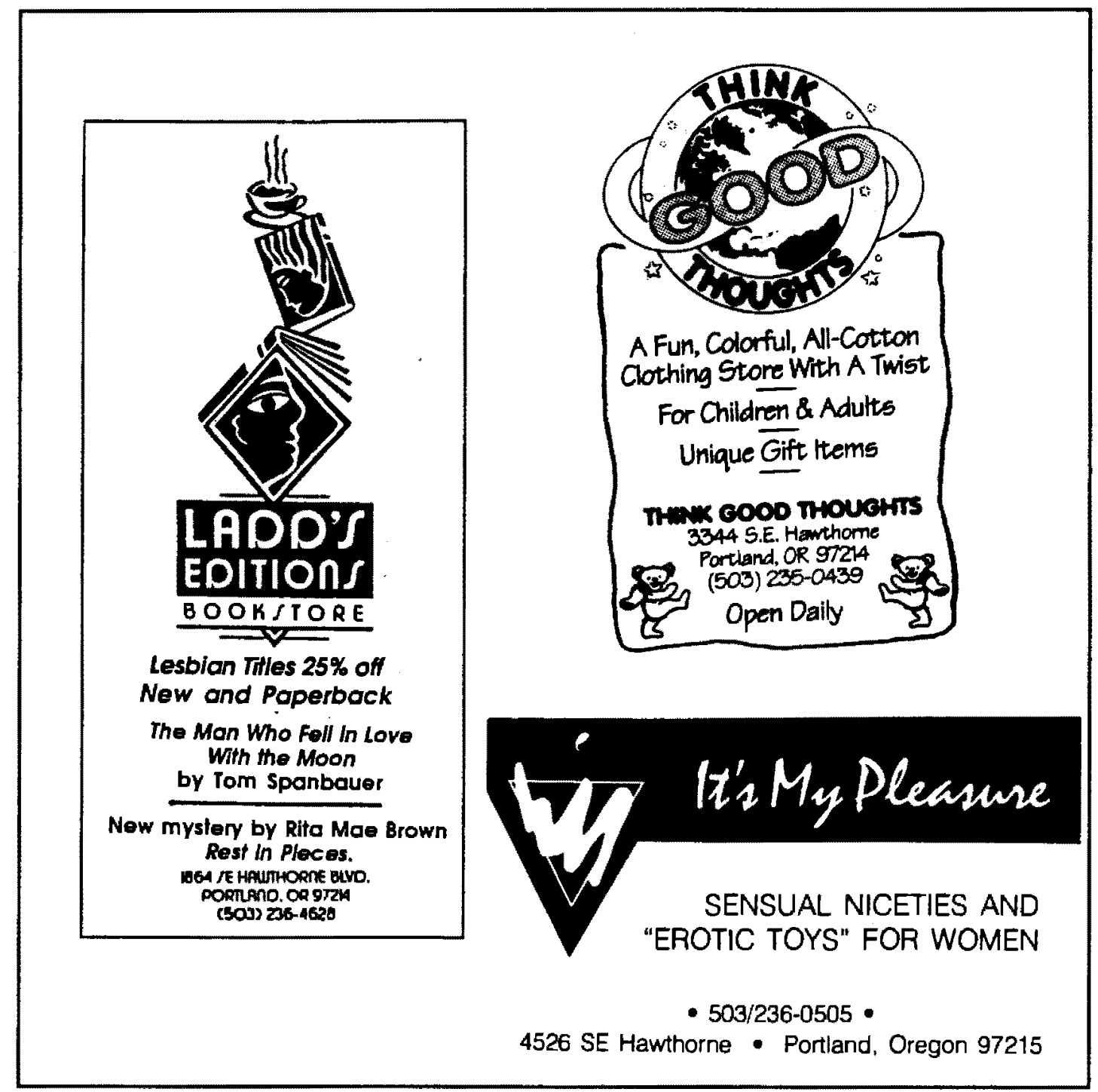

Figure 18. Advertisements from Ladd's Editions, Think Good Thoughts, and It's My Pleasure, reinforcing Hawthorne's feminist and politically correct images. 
However, other 'contrived' promotional activities are regularly undertaken by the business association. These organized ventures are designed to create a identity for the boulevard and are based on the desires of HBBA. The business association has a more formal image of Hawthorne than is apparent on the street, and the two images are somewhat in conflict. The impetus behind bringing publicity to the district lies with the Main Street Program (discussed in more detail in Chapter IV) and its efforts to create a 'sense of place' for Hawthorne.

A Main Street resource team recommended that Hawthorne Boulevard should have a distinct identity, to create a memorable impression of the district and attract public attention (Bogle 1986; DeGraff 1987a). In keeping with this, Hawthorne was declared "Boulevard of Flags" by the Mayor of Portland, Bud Clark, on Veteran's Day, 1986. The Central Eastside Lions now place 300 U.S. flags along the street, from the Willamette river to SE 50th Street, every 'flag holiday' - six times a year (Figures 19 and 20). This contrived image seems unnecessary because Hawthorne has a distinct identity without its being the Boulevard of Flags. It is also incongruous to see the stars and stripes fluttering outside stores which promote peace and recycling.

Another attempt to foster the district's identity was the development of a Hawthorne logo that is now used on all business association correspondence. It shows a view of Hawthorne Boulevard looking west from SE 38th and captures several of the boulevard's distinctive buildings, with downtown Portland visible in the background (Figure 21). The phrase 'Hawthorne District' is a reference 


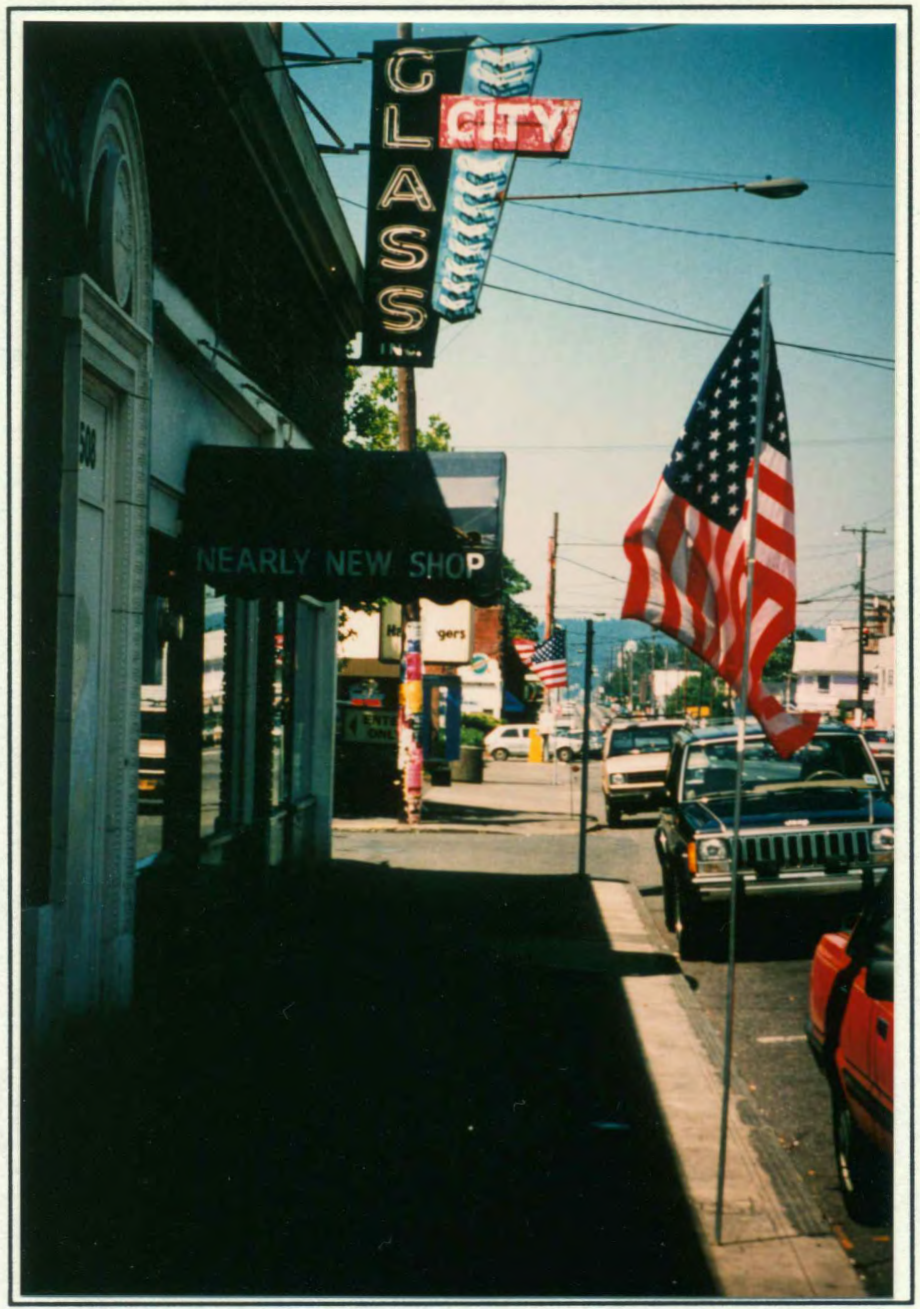

Figure 19. City Glass on Flag Day.

to both the commercial street and the surrounding neighborhoods, emphasizing the relationship between the two (HBBA May 1986). However, the business association does not represent all Hawthorne merchants, and many of the more 'alternative' stores are not members.

Wider efforts to enhance Hawthorne's image include an annual street fair in August and Christmas promotions. The Hawthorne Street Fair is the main way in which the district brings itself to the attention of city residents, although it is not 


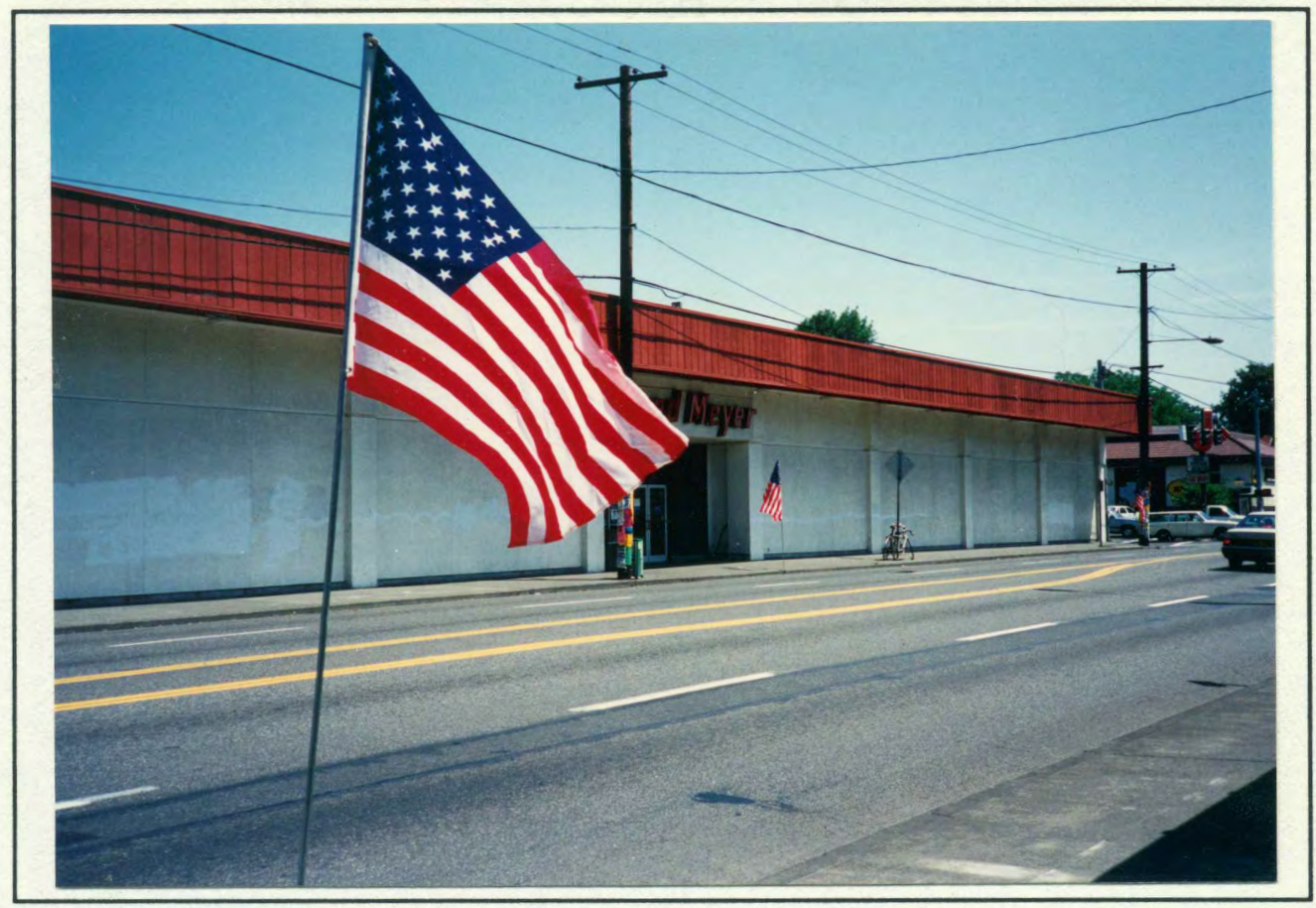

Figure 20. Flags outside Fred Meyer.

widely advertised. One merchant likened early street fairs to a large garage sale, but they improve and expand every year. Fairs started in 1984, but the first one under the Main Street aegis was in 1986. That year all merchants between SE 32nd and 40th participated (DeGraff 1986). Today, the fair spreads from 30th to 48th Streets. By 1987 forty-two street vendors participated in the fair - up from four in 1985 and twenty-six in 1986 (HBBA September 1987). An estimated 6,000 attended the 1990 street fair (HBBA September, October 1990).

In spite of its expansion, the Hawthorne Street Fair still retains something of a garage sale atmosphere. Merchants prop open their doors and put tables out on the sidewalks. Pedestrians must walk around racks of half-price clothes and tables strewn with secondhand books, negotiate sidewalk chairs and tables, duck 


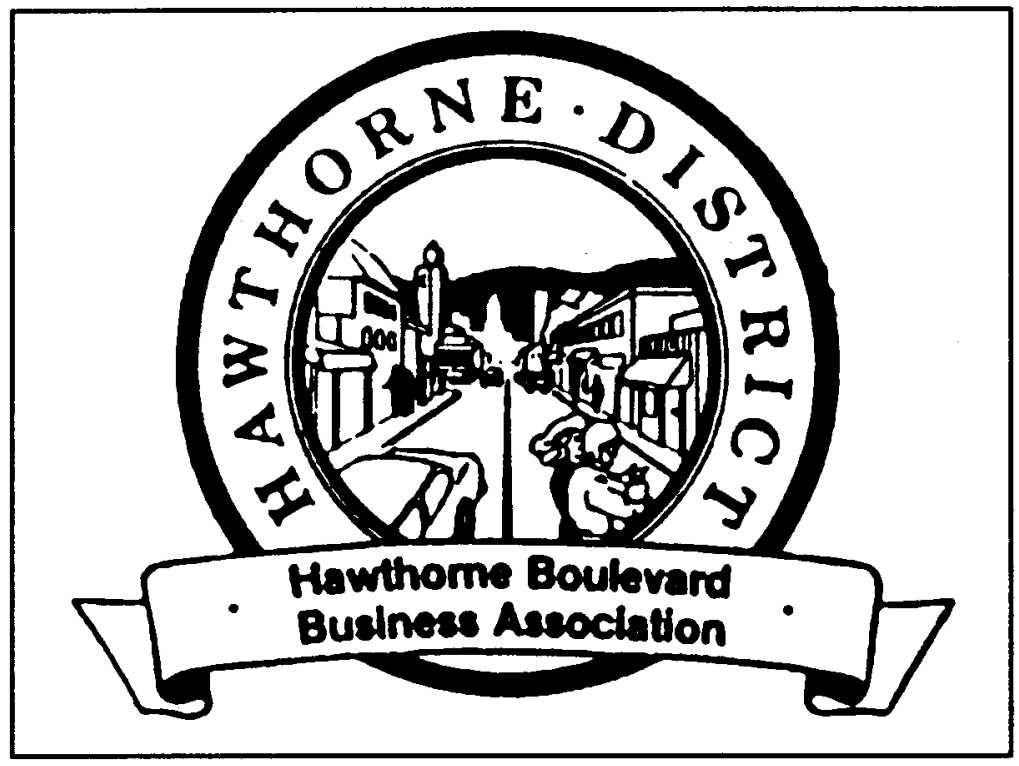

Figure 21. The logo of the Hawthorne Boulevard Business Association.

under banners and around A-frame advertising boards, risking life and limb to cross the street. Because HBBA has, thus far, been unsuccessful in closing the street to traffic, the fair takes place on Hawthorne's narrow sidewalks.

The poster advertising this year's street fair was the same design that is used as the cover of the current Hawthorne District Business Directory (Figure 22): "It's an Adventure, Explore the Possibilities." Tea-drinking animals in a boat hardly encapsulates the everyday image of Hawthorne, in spite of the Hawthorne location of The Cat's Meow, Man's Best Friend, Buttertoes Cards and Gifts and Kids at Heart (toys). HBBA has a one-sided view of the street's character, apparently based on how it would like the street to be seen. 


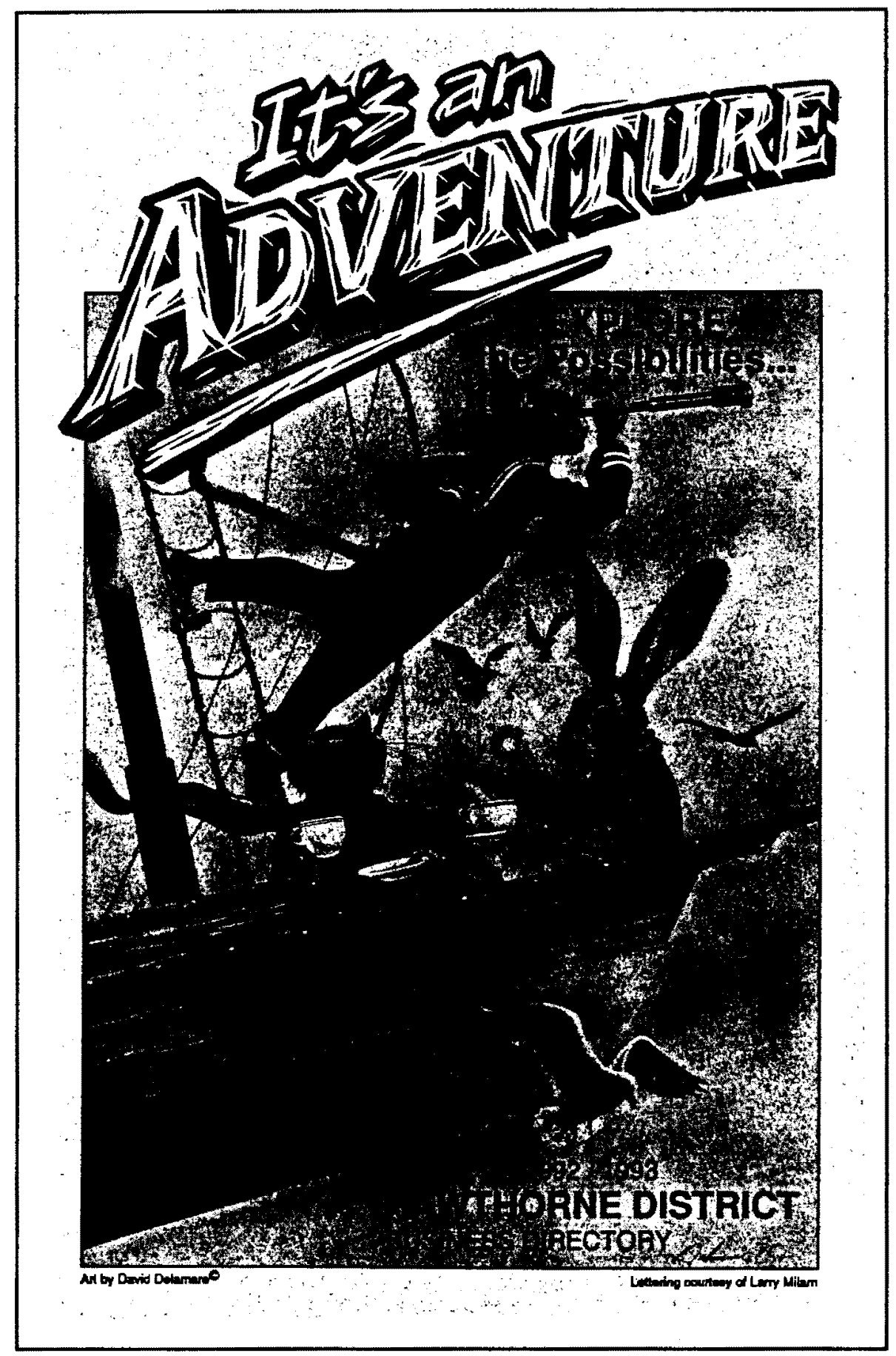

Figure 22. The cover of the 1992 Hawthorne Business Directory. 
Organized promotions, initiated by the Main Street Program, also occur at Christmas. In the December 1985 issue of The Gazette the Main Street manager, Rob DeGraff, suggested a 'Hawthorne Christmas lane' to "attract and brighten the spirits of those traveling on Hawthorne." By the following year this idea had blossomed into a full-scale operation: Fred Meyer's sold strings of lights to merchants at wholesale prices; holiday scenes were painted in many store windows; utility poles between 32 nd and 40 th were decorated with red bows; and caroler's strolled the boulevard on Saturdays (DeGraff 1987a). Christmas attractions continue to expand every year and, last year, included carriage rides and a window dressing competition (HBBA January, February 1992).

Most recently the basis of promotional activities has been Hawthorne's PC image. On April 25, 1992, there was an Earth Day walk along the boulevard, from SE 14th to SE 48th Street. The walk raised money for Sunflower Recycling, a local cooperative, and demonstrated support for Hawthorne merchants who use or sell recycled goods. A full page announcement in the neighborhood newspaper declared that "Hawthorne Boulevard merchants are living out the spirit of recycling by transforming a negative factor [the closure of the Hawthorne bridge] into a positive celebration" (Southeast Examiner May 1992, p. 8).

Billed as "Hawthorne Recycles - even its bridge" (ibid.; HBBA March, April 1992) the walk drew attention to the street during the Hawthorne Bridge closure and helped reinforce Hawthorne's PC image. Recycling was seen as a 'natural' theme for Hawthorne because of the street's concentration of used books and 
clothing stores and it being home to the offices of the Sierra Club (1413 SE Hawthorne) (ibid.).

The Main Street Program underpinned the actions of the business association between September 1985 and August 1988. In addition to formalizing promotional activities, it contributed to improving Hawthorne's image by encouraging physical improvements and creating a design plan. One of the primary goals of the national Main Street Program was "to foster an appreciation of good design" (Glisson 1984, p. 10) and many improvements on Hawthorne stem from HBBA's work promoting the renovation of buildings, the placement of attractive signs and awnings, and the refinement of parking and litter controls (DeGraff undated).

Twelve merchants ordered architectural renderings of possible improvements to their properties and several more used design assistance provided by the Oregon Downtown Development Association (ODDA) (ibid.). The first use of this service was the 1986 relocation of Accent Office Systems, a typewriter and calculator repair shop, into a store previously occupied by a children's clothing store, Dinky Duds. This change of use required extensive remodelling and ODDA's services were used fully (HBBA April 1986).

During the Main Street years many other businesses also improved their appearance. Two notable HBBA projects were the transformation of a vacant pharmacy into a specialist nursery (Dragonfly Gardens), and the remodelling and repainting of a vacant "hideous electric blue and green" auto parts store which 
became Brownell Sound (DeGraff 1987b; HBBA May 1987).

The Boulevard two largest properties, Fred Meyer and Safeway, both updated their appearance during the mid-1980s; many stores were furnished with new awnings (e.g. Second Generation, The Hawthorne Auto Clinic, JaCiva's Chocolatier); and the Can We Talk tavern modified its sign to just advertise "'dancers' without mention of their costumes or lack thereof" (HBBA November 1985)! Design awards were given to Pastaworks, Dragonfly Gardens and JaCiva's at the 1988 HBBA annual meeting (HBBA March 1988).

The Main Street Program also generated The Hawthorne Boulevard Landscape and Design Plan (ODDA 1987). This plan goes beyond simple improvements and proposes the creation of a distinct and delimited Hawthorne district. Such a district would be united by a single color scheme and distinctive street signs (similar to those in Portland's Yamhill Historic District and Chinatown). Also planned are clear entrances and termini to the Boulevard, marked with 'Welcome to Hawthorne' banners.

Such uniformity is intended to create a distinct identity and 'sense of place' for the whole street. The linearity of the district makes identity difficult to maintain: the plan states that there should be "a general sense of identity for the boulevard and a specific sense of identity for each subdistrict" (ODDA 1987, p. 4). Definition of distinct nodes along the street - at 12th, 20th, 30th, 35th to 39th, and 48th - may enable different sections of the street to develop/maintain different images. 
However, since the plan was written, Hawthorne Boulevard has developed its own sense of place. The appeal of Hawthorne lies with its unruliness. Implementation of the plan would have artificially created a very different place. Removing roof-top signs and colored fliers, and burying utility wires would strip Hawthorne of much of its character. Again, the wishes of the business association and the reality of Hawthorne are in conflict.

\section{A TRADITIONAL SHOPPING STREET?}

While Hawthorne Boulevard is a focus for diverse subgroups in Portland, it is also a neighborhood shopping street which caters to long-time patrons and families. The summer and Christmas promotions help reinforce the image of a traditional, neighborhood Main Street. Indeed, the western end of the district has yet to be influenced by the upgrading taking place just a few blocks away. West of 32nd Street, the businesses serve only the local market: there is the Hawthorne liquor store, a mom and pop grocery store (Lee's Express Grocery), and a dry cleaners (Springtime Thrifty Cleaners).

However, few vestiges of the neighborhood commercial strip are found in Hawthorne's revamped core. Completed surrounded by new stores, The Tu-Be Tavern, Len's Barber Shop and the vacant locksmith's store constitute a vestigial core of run-down service establishments reliant on the local market. High rents hastened the locksmith's departure and it seems unlikely that the other two will remain for long. Several of the music stores which heralded the start of 
specialization, mentioned in Chapter I, are still on Hawthorne. While 'old,' these were probably never neighborhood-focused businesses do not appear to be adversely affected by the changing function of the street.

Hawthorne prides itself on retaining its older customers and its appeal to families, but as service businesses disappear, much of the local custom disappears too. However, the district is becoming an increasingly popular family shopping destination. The shift towards retailing has played a large part in the street's increasing reputation for being a safe place for children.

Several merchants I spoke to noted how much safer the street is now compared to a few years ago. HBBA members have worked together to reduce the crime rate which increased as the district became more prosperous (HBBA April 1989). The business association formed a crime prevention committee in late 1990 and established a security foot patrol for the district (HBBA November, December 1990). During the first six months of the foot patrol there was a noticeable decrease in the number of transients, open drug deals, skateboarders and shop lifting on Hawthorne (HBBA July, August 1991). The visibility of the patrol also improves the perception of security for shoppers.

Safety on the street was further improved when it was announced in March of this year that a member of the Hawthorne area Portland police would carry a cellular phone so he could be quickly contacted by HBBA members (HBBA March, April 1992). Direct contact with the police has helped merchants cope with "trespassers, panhandlers, suspicious people and the public consumption of 
alcohol ... all those things that reduce the attractiveness of SE Hawthorne as a place to do business" (HBBA May, June 1992). In the same issue of The Gazette was an article about HBBA developing a strategy to exclude "persons exhibiting criminal behavior" from businesses.

Revitalization has given Hawthorne an image as a secure shopping district. The buildings have been renovated, there is more pedestrian traffic, and shops are open later, all of which give the district a more positive feeling. Members of the business association realize how important security is in people's perceptions of Hawthorne and have made a conscious effort to reinforce the feeling of safety on the boulevard.

\section{AN IMAGE OF GENTRIFICATION?}

The upscaling of stores and restaurants on Hawthorne has redefined the boulevard's position in Portland's retail structure, and what was once a run-down street of services has become the center of eastside style. This transformation has elevated Hawthorne to the position of being one of the city's most popular 'neighborhood' shopping streets, second only to NW 23rd. However, revitalization on Hawthorne has created a very different place from that usually associated with gentrified streets such as NW 23rd. Consumption is well-intentioned and wellinformed. One does not see the over-priced goods and high fashion of yuppie culture. 
Northwest 23rd Avenue, Portland's archetypal gentrified street, has already been referred to in this thesis. Here I describe it in more depth as a local example of more typical gentrification. Comparisons between the two streets stem from the replication of several stores and the dramatic upgrading of both districts. Although a transition from neighborhood to regional businesses, and from the commonplace to the distinctive, typifies both streets, that is where similarities end. Portland's two foremost sites of commercial gentrification owe their characteristics less to the shared process of upgrading than to the unique situations in which they developed. The built environment and the surrounding neighborhoods have created the distinct qualities associated with each district.

NW 23rd is poised between downtown and the elite residences of the West Hills. The area immediately surrounding it has undergone gentrification in the last decade, giving the area a reputation for being both stylish and expensive. Once an area of warehouses, inner Northwest Portland has become the fashionable place to live in the central city.

Inner Northwest's main pedestrian shopping streets, NW 23rd and its sister street NW 21st, cater to the wealthy and fashion-conscious who imbibe the atmosphere of self-conscious style along with their espresso. Specialty boutiques and gift stores huddle in the renovated Victorian buildings lining the district's core between NW Hoyt and NW Lovejoy Streets. Most of the buildings have at least two stories, some three or four, and there are no vacant blocks. This concentration of buildings on a two lane, tree-lined street makes NW 23rd a more 
physically attractive district than is Hawthorne. The former is more inviting to pedestrians because of its smaller scale and slower traffic. This adds to the 'traditional' shopping street atmosphere so popular in the present urban revival movement.

Where Hawthorne is thrown together, NW 23rd is 'designer.' There are numerous high-fashion clothes stores, galleries and highly specialized specialty stores: crafts from Zimbabwe; fashionable Western clothes; designer plates; and kites. It is the "window-shopping center for chic apparel, arty gifts, and housewares" (Irving 1990, p. 111). A bagel bakery, a deli and numerous expensive gift shops also mark NW 23rd as an expensive street. Two one-hour photo developing stores suggest that the street is more tourist-oriented than is Hawthorne.

While the westside trend-setter has evolved into a gentrified district like those in many other cities, the eastside seems destined, even eager, to remain behind. The east side of the river is still looked down on by those unfamiliar with it, and most of the money in the city remains on the west. A recent article on east Portland encourages people to cross the river cautioning that "it may not be love at sight but the area will grow on you ... keep an open mind" (Sunset, October 1992). It further suggests that "[L]unch is the safest introduction, since it represents only an hour or two of lost time if you're unimpressed." For a travel magazine to describe crossing the Willamette thus illustrates the negative impressions that exist about the eastside of Portland. 
For Hawthorne to equal NW 23rd it would have to lose its eastside image, something that would be as unpopular as it is unlikely. The owner of The Cat's Meow tells of phonecalls from potential customers asking if it is safe to park on the street outside her store ${ }^{1}$ ! She has recently opened a second Cat's Meow on NW 23rd, no doubt catering to those who have doubts about the eastside.

\section{SUMMARY}

Hawthorne's distinct image rests on its unique blend of styles and its casual atmosphere. It is not a product of a relatively homogenous yuppie culture, but a fusion of several urban lifestyles and value systems. A wide variety of lifestyles and values are represented in the street's commercial activities; it serves a number of communities without propinquity (Palm 1973) - each too small to have its own locational focus. Perhaps the emerging Hawthorne subculture, such as it is, can be best summarized by a term coined by Godfrey to describe Haight-Ashbury's changing social composition in the 1980s: the "hipoisie." This group is described as "youngish, white, relatively affluent, socially liberal, but still somewhat varied in personal orientations and lifestyle" (Godfrey 1988, p. 191).

Hawthorne's popularity stems from its unique mix of old, close-packed buildings, its lively stores and their liberal patrons. Overlying these intrinsic aspects of the district is the business association's work promoting Hawthorne as a

${ }^{1}$ Personal communication with Pam Gibbons, owner of The Cat's Meow, 3538 SE Hawthorne Boulevard and 816 NW 23rd. 
family-oriented specialty district. While contrived images - such as the Boulevard of Flags - jar against the broader image of Hawthorne, they increase public awareness of the district and help attract more people. Hawthorne can attribute much of its success to this multi-faceted image which draws diverse people from all over the metropolitan area. 


\section{CHAPTER IV}

\section{HAWTHORNE'S UNIQUE SITUATION}

This chapter considers the features that set Hawthorne Boulevard apart from other eastside commercial districts. There are three primary factors underlying Hawthorne's advantageous position: its location; the Main Street Program; and its surrounding neighborhoods. First, the boulevard has historical and geographical advantages - the Hawthorne Bridge and Mount Tabor - which create an inherent sense of place. Southeast Belmont and Division Streets, its immediate commercial neighbors, lack these markers of an identifiable place and are further disadvantaged by their physical makeup and zoning. Second, Hawthorne's position was advanced by its participation in the Main Street Program, a funded program specifically aimed at improving the economic and physical well-being of traditional shopping streets. Third, the residential areas immediately adjacent to Hawthorne are home to diverse subgroups of people with an increasing income and education levels.

\section{GEOGRAPHY}

Hawthorne Boulevard's original development and subsequent revitalization is attributable to several physical and historical coincidences. Construction of the Hawthorne Bridge and the extension of a street car line along the boulevard 
encouraged linear commercial development early in Portland's history.

Hawthorne has lost most of its street car era buildings but retains a historic legacy in its built environment: many later structures were constructed at a pedestrian scale in keeping with early development.

Hawthorne's position within Portland is, perhaps, best summed up by the HBBA President, Roger Jones's, Message of November 1985, just after the Main Street Program began:

Hawthorne Boulevard is a unique business area with natural geographic boundaries in the drawbridge and the live volcano. These boundaries held back the potential growth of this bridgehead traffic arterial. Thank you, Mount Tabor, because you are the reason that Hawthorne doesn't have the Burnside, Powell, Sandy Boulevard traffic and thus the auto oriented "strip commercial" blight that has no sense of place. This "sense of place" is what we are preserving and nurturing on Hawthorne as it is one of the very few left in the Rose City. (HBBA November 1985, italics added).

- Hawthorne is thus unique among neighborhood commercial streets in having a distinct beginning and end: as the bridge funnels traffic onto the Boulevard so topography prevents Hawthorne from becoming yet another route to the suburbs. Because its eastward extension is halted by Mount Tabor, Hawthorne is a less effective arterial than is Division Street.

The boulevard's location gives shoppers striking vistas at both ends of the street: Mount Tabor to the east, downtown to the west. Add to this a prominent downtown bridge at the end of, and named after, Hawthorne Boulevard and you have a ready-made identity for the boulevard. Being directly associated with a central and distinctive span of the Willamette River creates a sense of unity and 
image for Hawthorne Boulevard. The importance of name-recognition should not be overlooked because awareness of the district's existence maybe reinforced by the synonymous bridge. (Coincidentally, the two other trendy shopping districts on the east side of the Willamette - Northeast Broadway and Sellwood - are also associated with bridges.)

Hawthorne's geographically closest commercial neighbors, Belmont and Division, have not undergone similar revitalization and, in spite of recent claims of budding gentrification (Southeast Examiner (S.E.) March, July 1992), both streets remain poor cousins to Hawthorne. Determining why revitalization focused on Hawthorne involves not only clarifying the features that put the boulevard in a advantageous position but, also, the factors which place its neighbors at a disadvantage. Both Belmont and Division have hopes of becoming secondary foci for revitalization in inner southeast like the $21 \mathrm{st} / 23 \mathrm{rd}$ revitalized couplet in Northwest Portland. Rather than competing against NW 23rd, NW21st serves as a subsidiary attraction that benefits from its neighbor's customers and helps expand the former's business district. It is this auxiliary role that both Belmont and Division wish to play to Hawthorne's lead.

The two streets have several features in common not least of which is the proximity of Hawthorne Boulevard, the success of which may have stunted development elsewhere. (Belmont is six blocks north of Hawthorne, Division is ten blocks south). Both have physical environments and zoning that make pedestrian-oriented revitalization more difficult than it was on Hawthorne. 
Nevertheless, Belmont and Division are both upgrading. This section addresses each street separately, looking at recent improvements and how the status quo works against either one becoming another Hawthorne.

SE Belmont Street is, like Hawthorne, a former street car line ending at Mount Tabor. However it lacks Hawthorne's continuous stretch of distinctive buildings and direct connection to downtown. Furthermore, it is one-way for much of its length so traffic is inclined to travel faster and only be aware of one side of the street.

Belmont's most serious drawback, that which prevents it from "playing Northwest 21st to Hawthorne's Northwest 23rd" and serving as a secondary focus for revitalization in Southeast, is the 1980 down-zoning of many properties because of a perceived excess of commercial land (Harrison 1980, p. 9). Downzoning - the assignment of residential zoning to commercially-used land - created numerous non-conforming uses along Belmont (S.E. March 1992).

Because banks are reluctant to lend money on properties which do not comply with current zoning codes, many structures have not been repaired, improved or expanded since the introduction of the 1980 Comprehensive Plan. Today, much of the Belmont business district is in a state of disrepair. Comparing Belmont's position to that of Hawthorne, Belmont Business Association president, Chris Brandt, describes down-zoning as "one of the serious blights . . . extremely injurious to this street, and it did not occur on Hawthorne. Hawthorne was left intact" (ibid.) 
Belmont is currently zoned as blocks of commercial property interspersed with high-density residential land. Nowhere are there more than four consecutive blocks of commercial zoning. Attempts to create a nodal business district on Belmont destroyed many of Belmont's hopes of following Hawthorne; a pedestrian retail district with a distinct identity cannot be established where the zoning does not allow continuous stretches of retailing.

Furthermore, the mix of businesses on Belmont is not oriented towards pedestrian shoppers. Several shop fronts are being used as storage by a mattress manufacturer, making Belmont's situation similar to that faced by Hawthorne ten years ago when Union Furniture dominated the boulevard. Other businesses on Belmont include two convenience stores, a tavern, a couple of dry cleaners, a light fixture store, and several restaurants - including Genoa, "[Portland's] best location for a prix fuxe northern Italian dinner" (Willamette Week October 1992). Specialty retailing is beginning to appear on Belmont with the recent opening of Periodicals Paradise and Balloons Over Portland.

While residential zoning prevents it from being a pedestrian shopping district and many of the business uses are not conducive to pedestrian traffic, there are murmurs of revitalization on Belmont. A recent newspaper article announced that "there's a buzz on Belmont, a sense that the street could be awakening to the same process that turned Northwest 23rd and Hawthorne Boulevard into icons of urban revitalization in the '80s" (ibid.). Changes in the housing market, a recent increase in retail businesses, and the opening of a holistic 
medicine center are cited as proof of Hawthorne-like trends.

Belmont merchants hope that REACH - a community development corporation that has been renovating housing in inner southeast for a decade - will take charge of revitalizing Belmont this fall. Merchants see the vitality of the street depending on what use is made of the vacant dairy building on SE 33rd and Belmont (ibid.). It is one of the largest buildings on the street and appropriate renovation could spark further upgrading on Belmont.

Similarly, merchants on Division await the reuse of a large vacant building which could hold the key to the street's revitalization. A recent headline in the local newspaper read "Renaissance on Division. Specialty shops gain hold after larger retailers leave" (S.E. July 1992). The related article claims that "inner southeast's concentration of health-conscious sophisticates" has Nature's Fresh Northwest, an organic grocery store, looking at the street as the site for its next store. Although Natures is attracted to the neighborhood rather than to Division per se - the company also considered the dairy on Belmont and a building on 22nd and Hawthorne left vacant when Dragonfly Gardens, a specialty nursery moved to Division - a vacant furniture store on SE 30th and Division has recently been confirmed as the new location for the store.

Division has reason to be optimistic. In addition to Dragonfly Gardens, recent months have seen several specialty retailers and restaurants - including a couple of coffee shops - opening their doors on Division. The relocation of the Oregon Museum of Science and Industry (OMSI) to the east bank of the 
Willamette River, at the foot of Division, is expected to increase traffic and improve business on Division. The president of the Division Street Merchants Association, Phil Moulton, was quoted as saying the street is getting to be like Hawthorne was in its beginning stages (ibid.)

However, a revitalized Division Street will not become another Hawthorne because it is a quite different business street, both physically and functionally. Division is an arterial street connecting Inner Southeast Portland to the suburbs, the city of Gresham, and beyond. Because attracting car-based shoppers requires larger scale architecture and brasher signs than does promotion aimed at pedestrians, the street has less charm than does Hawthorne. Many of Division's commercial properties are large, utilitarian buildings so it does not have the visual pull of Hawthorne or even, potentially, Belmont. Additionally, there is no locational focus to the street: residential buildings as well as several vacant lots are scattered among the commercial structures creating a nodal business district which lacks visual unity.

Division's business mix is similar to that of Hawthorne twelve years ago in that service provision, rather than retailing, forms the functional core of the district. The recently arrived delis and cafes jostle for room between furniture refinishers, appliance repairers, auto mechanics and second-hand stores. The combination of heavy traffic, large buildings and physical breaks in the business district hinder the development of the pedestrian orientation characteristic of Hawthorne and other gentrified streets. 


\section{THE MAIN STREET PROGRAM}

Hawthorne's advantageous position was advanced yet further by the street's participation in the National Trust for Historic Preservation's Main Street Project between 1985 and 1988. Established in 1977, this national program links historic preservation and economic development in the revitalization of small downtowns and retail districts. In Oregon the program is administered through the Oregon Downtown Development Agency (ODDA), under the auspices of the National Main Street Center. A four-fold approach based on organization, promotion, design and economic restructuring encourages old commercial districts to make full use of their aesthetic advantages while benefitting from the unified management techniques of shopping malls.

Successful applicants for the program are selected on the likelihood that they will realize their goals of revitalization; districts must have architecture worthy of preservation and a stable economic base. Hawthorne was an ideal candidate for Main Street because it had a good mix of businesses, few vacancies, and an organized business association (Bogle 1986, p. 6). By 1985 the groundwork was already in place for an organized venture to come in and supervise the district because HBBA already had "a sense of community dedication and purpose in the revival of Hawthorne Boulevard" (HBBA September 1985).

The Main Street program succeeds only if its four aspects are managed together. It is based on assumptions that: gradual improvements will lay a sounder foundation for the future than will a one-shot scheme; both public and 
private sectors must be involved; centers must make best use of their unique qualities; the program must maintain a consistent high quality; and full-time management is required (Glisson 1984, p. 14). Once Main Street on Hawthorne was confirmed, HBBA touted the program in its monthly Gazette as "a four-in-one blockbuster guaranteed to make every merchant's dream come true and bring a smile to young and old alike" (HBBA August 1985).

A resource team visited Hawthorne in March 1986 to assess the street and recommend actions to fulfill its potential (HBBA March 1986). They saw Main Street as helping the Hawthorne business district in the following ways:

Organization -- the business association lacked both merchant and neighborhood participation, two essentials for a successful program. Moreover, a tendency to plan rather than act was impeding progress. Recommendations that these problems be overcome and that the project manager be given a large degree of freedom were proposed (Bogle 1986, p. 21-25).

Promotion -- to further publicize Hawthorne, the Main Street team suggested the development of a logo and slogan to be used with all HBBAsponsored advertising. Contact with the media, more special events and "strict adherence to uniformity and consistency" were encouraged as the most effective ways to consolidate and expand Hawthorne's image (ibid., p. 17-21). The boulevard was to be marketed as a destination for people to gather for community events as well as to shop (HBBA 1985).

Design -- improving the visual packaging of Hawthorne with attention to its 
physical character communicated through buildings, signs, window displays and public areas. Goals ranged from removing obsolete signs and providing guidance on effective window displays, to screening parking lots and burying power lines. Hanging baskets, street trees and awnings were also recommended. ODDA made inexpensive architectural guidance available to businesses wishing to improve their properties (DeGraff 1986).

Economic Restructuring -- the resource team suggested Hawthorne's business mix could be refined by analyzing the trade area, and using this information to identify unfilled demand. Combined with an inventory of existing businesses and vacant properties, this would enable HBBA to recruit businesses with a good chance of succeeding on the boulevard. Low interest loans were recommended to help merchants expand, renovate or buy their properties (Bogle 1986, p. 14-16).

Rob DeGraff was hired to implement the program as Main Street Manager. His job, acting through HBBA, included increasing communication between business owners, recruiting businesses and acting as an intermediary between vacant properties and businesses wanting to move to Hawthorne (DeGraff undated). As the program was funded for only three years (September 1985 - August 1988) not all the resource team's recommendations came to fruition. The program's achievements - assembled from DeGraff's quarterly reports to Portland Development Commission and the HBBA Gazette - can be summarized thus: 


\section{$\underline{\text { Organization }}$}

This is the most important, but least conspicuous, aspect of the Main Street program for without it nothing else can succeed. Organization has enabled HBBA to implement its plans more effectively. Personal contact between merchants was increased by the introduction of quarterly 'Business After Hours' meetings, encouraging people to get to know one another and discuss common goals and problems. Such was the importance of getting merchants together that door prizes were offered as incentives to attend meetings (HBBA February 1986). Improved communication led business owners to unite against two of the boulevard's major problems - litter and crime. Campaigns against litter, particularly posters on utility poles, met with some success (HBBA January 1986, January 1987). There is much less garbage on the street than there was in the early 1980s (Portland Bureau of Planning 1981), but utility poles are still covered with flyers. More successfully, the Hawthorne merchants organized a Business Crime Watch and created a phone tree to alert each other of criminal activity (DeGraff 1987a). The success of this scheme led to its later expansion and the present day employment of security guards on the boulevard.

\section{Promotion}

Many of Main Street's achievements have already been addressed in Chapter III on the boulevard's image. Expansion of the annual Hawthorne Street Fair was the project's main promotional project. Although it existed before Main Street came to Hawthorne, the program focused attention on the fair as the best 
way to bring people's attention to the district. The fair has grown every year and will be boosted next year by the closure of the street to traffic for the first time in the fair's history. Main Street also initiated the development of a logo depicting the Hawthorne business district, and began the Christmas promotions.

\section{Design}

HBBA also established a design committee to develop a plan for the placement of street furniture and trees along the boulevard ("a plan for such plantings that beautifies the street, yet obstructs storefronts and sidewalks to the least degree possible") (HBBA November 1987) (DeGraff 1987a). By early 1987 the design committee had inventoried the boulevard's buildings with regards to their need for maintenance and repair, to determine which properties could make best use of an Investor's Rehab Loan (IRL) program (DeGraff 1987b).

At the end of the Main Street program, in September 1988, seven HBBA design projects had been completed and four more were in progress. No-one had made use of the IRL program but it was hoped that two projects, still in the planning stage, would do so. The draft design plan was being reviewed and HBBA was hoping to be able to implement it (DeGraff, undated). The plan was never implemented due to lack of money, but it remains a 'wish list' of how the HBBA would like Hawthorne to look. 


\section{Economic Restructuring}

In its summary of Main Street progress, ODDA lists the new businesses, jobs and building renovations on Hawthorne. Between September 1985 and June 1988 there were sixty-nine new businesses and thirty-seven failures or moves away from Hawthorne, giving a net gain of thirty-two businesses; 143 jobs were created and sixty-eight jobs lost, a net gain of seventy-five. Some fifty-six buildings were rehabilitated at a total cost of $\$ 3,631,450$ (ODDA 1990).

Overall the Main Street project achieved HBBA's goals (DeGraff 1987a): to strengthen, expand and develop HBBA; to promote the whole district by sponsoring events and activities that encourage community relations, business growth and fun; to create an attractive, identifiable sense of place that is friendly, convenient and functional; and to encourage economic expansion while maintaining the integrity of a neighborhood commercial district.

By adopting the Main Street position of 'revitalization through preservation' (Stewart 1985, p. 63) and capitalizing on its aesthetic advantages Hawthorne has stood up to the competition provided by the Lloyd Center, a nearby shopping mall. The boulevard has flourished because better organization has focused the business association's energies into physical and economic improvements, and effective promotions. "HBBA's approach has been to promote the area as a destination for city residents and a provider of local goods and services to the neighborhoods" (DeGraff undated) and, as such, Hawthorne developed into both a more appealing local shopping district and a more successful regional center. 
Writing towards the end of his tenure, circa June 1988, Rob DeGraff noted that, although the program had been largely successful, it was not complete. Remaining vacancies and a continued need for renovation provided an opportunity for broadening the business mix and further improving the district's appearance (DeGraff undated). Most of Hawthorne's potentialities have since been fulfilled, and the physical and commercial makeup of the district continues to improve.

Main Street's legacy lives on, four years after the program's completion. The greatest reminder of the program is a sense of unity among Hawthorne merchants: bi-monthly meetings provide members with a forum where they can share opinions and develop plans. The business association continues to be a vital force in the organization of street - largely on a volunteer basis - providing advice and coordinating promotional activities. Improved organization has helped further strengthen Hawthorne. The street fair and Christmas promotions are expanding annually, and renovation of the building stock has continued apace. Indeed, The HBBA Gazette of July/August 1990 announced "the Hawthorne Renaissance [where] ... dozens of shops have opened or upgraded along Hawthorne in the last 18 month [sic]." Main Street boosted this renaissance.

During its three years the Main Street Program advanced the boulevard's position as one of the few successful pedestrian shopping streets in southeast Portland. The demand for specialty goods is limited and the Hawthorne monopoly has largely excluded nearby streets from expanding their regional 
markets. Indeed, as noted above, its growth has probably retarded the development of Belmont and Division Streets.

Yet even before Main Street, Hawthorne had was better off than its commercial neighbors and was already regarded as a district with potential. Hawthorne was improving without a full-time manager and it is difficult to determine which of the program's achievements would have occurred without outside intervention. Commercial districts elsewhere have undergone revitalization without specific programs to help them.

Hawthorne would probably have reached its current state even without Main Street but, by actively promoting physical and economic improvements, the program hastened revitalization. Although advances were made in all four of the program's concerns, its greatest contribution was changing the way members of the business association think about the boulevard.

This shift in attitudes occurred in two ways: 1) merchants became aware of what successful revitalization entails; 2) improved organization encouraged merchants to their combine resources for the benefit of Hawthorne as a whole. An understanding of what is likely to succeed places merchants in a better position to use their resources wisely while organization helps business owners to work together in the promotion and protection of their district.

This shift in attitudes is one legacy of Main Street that may not have developed without the program and is the main achievement of the program that many present day merchants recognize. Overall, Main Street unified the business 
community and sped up the revitalization process and is, thus, partly responsible for the distinctive character of today's Hawthorne.

\section{THE NEIGHBORHOOD}

While Hawthorne's suitability for revitalization came from its geographical and historical position within Southeast Portland, and was furthered by its participation in the Main Street Program, the direction this revitalization took can be attributed to the character of the surrounding neighborhoods. Revitalization has transformed Hawthorne Boulevard into a regional center which reflects neighborhood character. While a residential district's character can be inferred from the types of businesses (Godfrey 1988; Jones and Simmons 1987), this can be confirmed qualitatively by examining local newspapers and, quantitatively, by analyzing census data. The content of publications about Inner Southeast reveal the issues considered important by the neighborhoods; census data show how the area's economic status has changed over time and compares to other parts of Portland.

Much can be revealed about a district's self-image from its local newspaper. Inner Southeast Portland is served by the Southeast Examiner, a free monthly tabloid which combines neighborhood boosterism with discussion of issues facing inner southeast. Recent editions have addressed issues such as the establishment of the Anti-Bigotry Coalition (S.E. April 1992); 'coffee consciousness' and how to be PC in your caffeine consumption (September 1992); new classes at Health 
Quest, the naturopathic health center on 39th and Hawthorne (ibid.); and possible Hawthorne-like trends on Belmont and Division (March, July 1992).

Browsing through the Southeast Examiner confirms inner southeast to be an area undergoing a bohemian form of revitalization which locals fear to be gentrification. Three regular features in the local newspaper provide insight into the quasi-gentrifying neighborhoods which surround Hawthorne: View from the Radical Middle (a column by State Representative Beverly Stein); The Joy of Repair (a light-hearted look at renovating old houses); and The Old Fossil (an idiosyncratic insight into neighborhood history).

The first feature, View from the Radical Middle, is Representative Stein's opinions on pertinent issues such as education, health care, tax reform and water conservation. Assuming Stein truly represents her district, the 'radical middle' is where inner southeast stands politically. This confirms the pro-choice, anti-Bush, environmentalist trend seen on Hawthorne Boulevard. Equally, renovation of old residential areas and an appreciation of local history are noted aspects of neighborhoods undergoing gentrification - both are amply covered by the Examiner. (A 'home restoration' specialty mall, in a refurbished warehouse, has recently opened in the nearby Buckman neighborhood on SE Grand Avenue.)

Gentrification is, indeed, a real concern for the area and it has been addressed in several recent issues of the Examiner. The April 1992 issue contained an article on five neighborhood diners (one on Belmont, one on Division, none on Hawthorne), supporting the working class origins of the area 
and bemoaning the loss of traditional eating places in the wake of "franchised fastfood frenzy" (S.E. April 1992). In one diner, the author and a companion "start talking about the dangers of creeping gentrification and our worries about the growing shortage of places where somebody can go and sit around, just sort of . . . be" (ibid., italics in original). The implication that one cannot 'be' in gentrified eateries is a clear criticism of the direction the neighborhood is heading.

The disappearance of diners is, however, of less concern that the appearance of row houses. The front page of a recent issue screamed "Row houses arrive on Hawthorne. Can gentrification be far behind?" (S.E. May 1992). The suspicion with which people regard row houses led the developer to invent the term 'bungarows' "so people wouldn't be scared" (ibid.). For people to be potentially scared by such construction, and its connotations, indicates the unpopularity of gentrification as a concept. The houses in the article are on SE 37th, just south of Hawthorne (Figure 23); the same developer plans to build more 'bungarows' on SE 12th and Stevens, about a mile and a half west of 37th. The sign announcing the proposed construction has been spray-painted 'DIE YUPPIE SCUM' (Figure 24) - a common epithet used against perceived agents of gentrification.

If row houses, or even bungarows, are indicators of such changes then the area is undergoing residential gentrification. The Examiner article quotes Mike Saba (senior housing planner at the city Planning Bureau) as saying southeast is 'the next stop' on the gentrification bandwagon of which "upgrading of the 


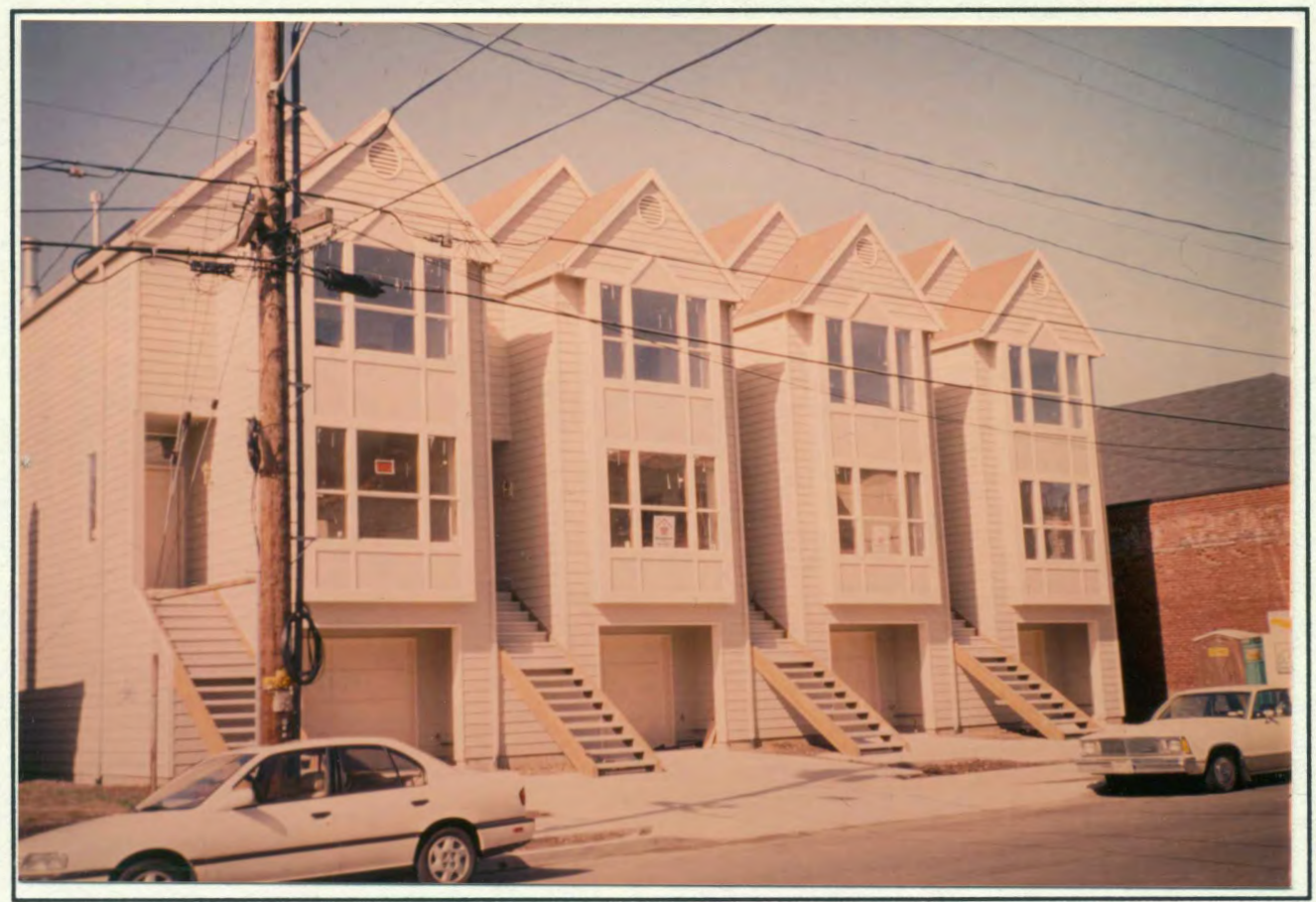

Figure 23. Row houses on 37th and Hawthorne.

Hawthorne commercial strip is just an indicator" (ibid.). The copy reads "with Hawthorne being compared more and more to Northwest 23rd Avenue, it appears inner southeast may soon become too expensive for a growing segment of its current population."

The author cites statistics - compiled by Multnomah county tax assessor - to support this view (ibid.):

- between 1988 and 1991 the average price of a southeast house leapt from $\$ 43,500$ to $\$ 71,300$.

- houses located between SE Division and SE Stark, and between 20th and 39th, increased in value from $\$ 39,000$ to $\$ 65,500$ in the same period.

- most house prices have increased by $25 \%$ during the past year. 


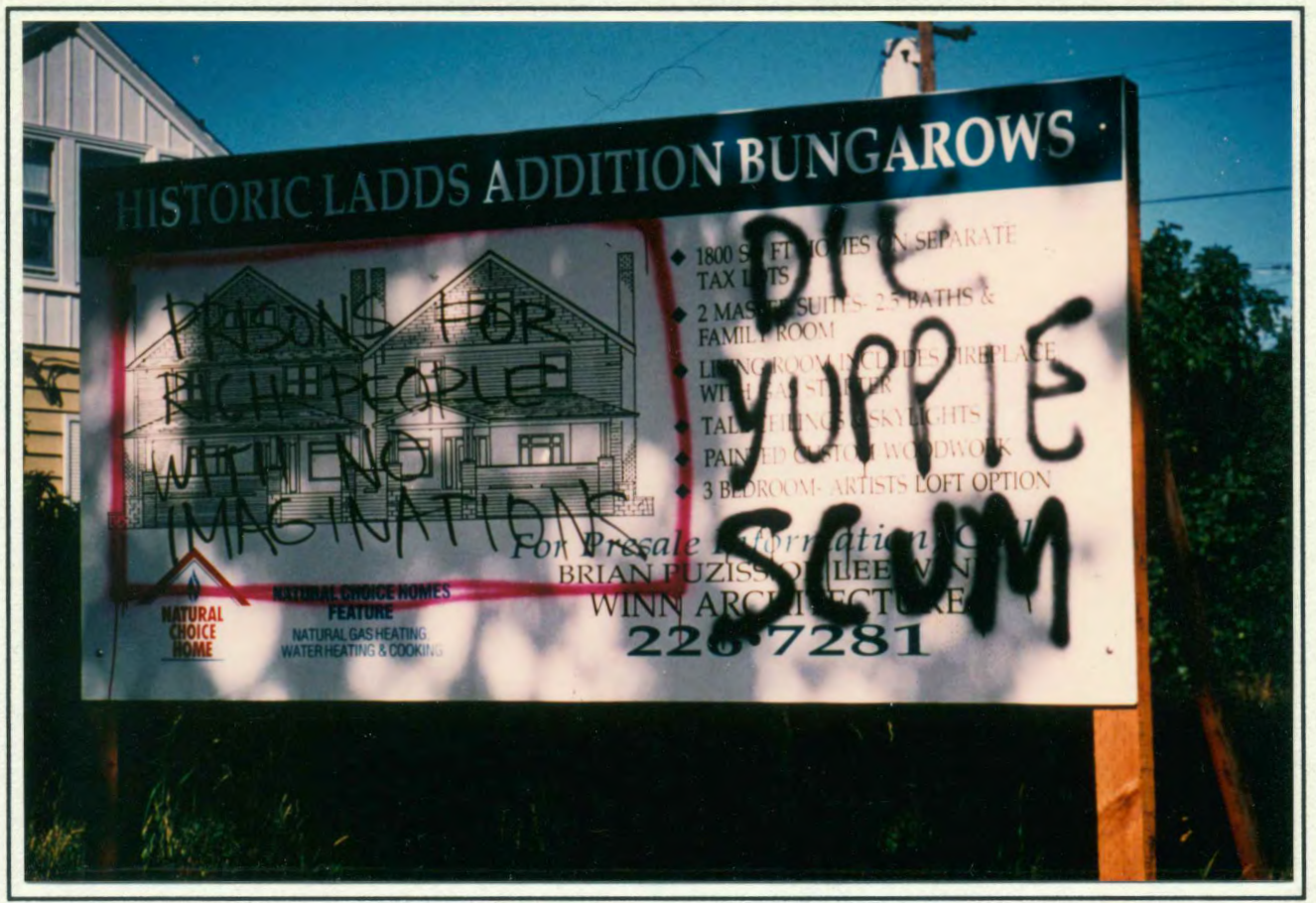

Figure 24. Graffiti directed at potential row house owners.

Upgrading trends have not gone unnoticed by Portland's daily newspaper

The Oregonian which recently published an article on the 'Richmond Renaissance' (26 April, 1992). The article focuses not on gentrification but on improvements being made to a run-down neighborhood. One house is described as "Southeast Portland chic at its finest, casually furnished with second-hand finds, decorated with personal shrines and art made by housemates, strewn with guitars, pillows, bikes and piles of clothing ... the lawn, in true Southeast fashion, is half-mown" (The Oregonian 26 April 1992). This is hardly the image of gentrification but, rather, one of a bohemian district unconcerned by outward appearances.

The thin line between simple upgrading and gentrification is a noted concern within the neighborhood: 
Residents are also talking about the benefits and disadvantages of gentrification. They don't want another Northwest 23rd Avenue developing in their area. On the other hand, some say, it's nice to be able to find a good cappuccino nearby (ibid.).

Although people are glad to see their neighborhood improving, they are wary of gentrification, regarding it as revitalization gone too far. As ever, NW 23rd is seen as evidence of what can happen when upgrading gets out of hand. Gentrification is seen ambiguously: people dislike the idea but are happy to take advantage of those aspects of it they enjoy.

One further example of the type of area inner southeast is can be found in neighborhood opposition to a Burger King franchise trying to establish a drivethrough restaurant on 39th, just south of Hawthorne. Construction of the fastfood outlet would have required a precedent-setting zone change, and the demolition of two houses, and brought more traffic to an already busy intersection. After months of legal wrangling the zone change application was turned down in July of this year. The fight, led by local neighborhood associations, illustrates the importance residents place on retaining their neighborhood's character, and the strength of grass roots activism. Neighborhood support was further demonstrated when the Bagdad Theatre held a special benefit to help cover the $\$ 3,700$ in legal fees owed by neighborhood associations (S.E. April 1992; The Oregonian 26 April 1992).

The bohemian character of inner southeast Portland is further confirmed by two very different studies. The first is The Clustering of America (Weiss 1988) in which forty neighborhood types (clusters), covering every American zip code, 
are described based on marketing and voting information. Fortuitously, Hawthorne's zip code, 97214 , is exemplified. The book outlines characteristics typical of similar zip codes throughout the country. The second, Gender and Space: Lesbians and Gay Men in the City (Adler and Brenner 1992), characterizes inner southeast Portland as a spatial concentration of lesbians and identifies the features which attract lesbians to the area.

Weiss's division of America into lifestyle clusters is intended for popular reading and uses summarized marketing information to describe each cluster. In describing the cluster nicknamed Single City Blues, Weiss makes direct reference to zip code 97214 (Figure 25), of which Hawthorne Boulevard is the main commercial axis (Weiss 1988, p. 37). Specific mention of inner southeast Portland strengthens the applicability of this work.

Single City Blues accounts for $3.3 \%$ of U.S. households and is described thus:

the largest segment of people under 35 and earning less than $\$ 20,000$ a year - places like . . . Southeast Portland, Oregon . . . a poor man's bohemia ... [where] neighborhood status is measured not in take-home pay but in the intellectual awareness expressed by high subscription rates to magazines like Harpers [and] Atlantic Monthly. A greater than average number of residents also belong to environmental organizations and publish magazine articles (ibid., p. $37-8)$.

Members of this group are more likely than the average American to travel by railroad, belong to environmentalist organizations, buy rock records, drive Japanese cars, and consume bottled water, whole-wheat bread and low-fat milk. They are less likely to play video games, go hunting, own wood burning stoves, drive American cars, and buy presweetened cold cereals, cheese spreads and 


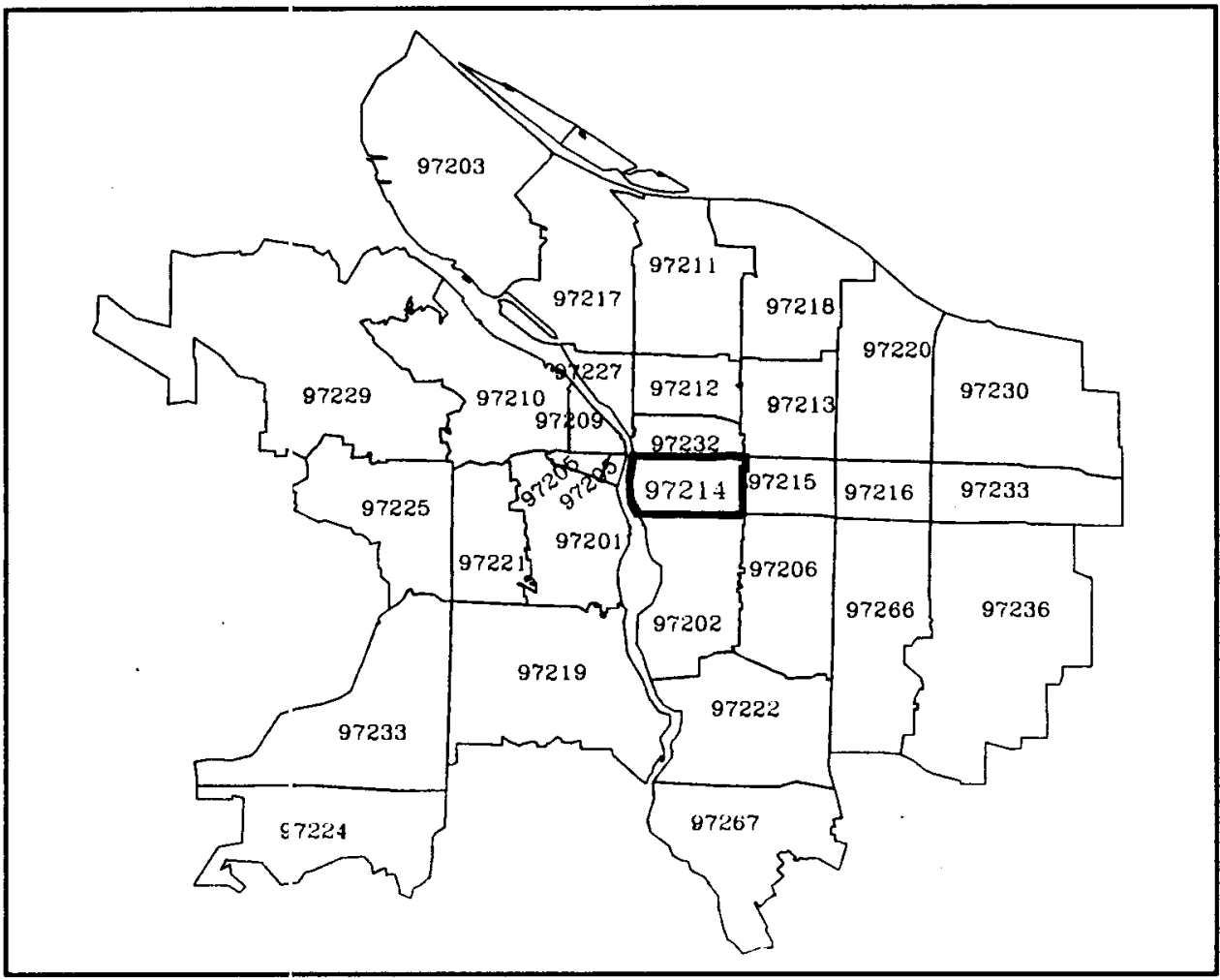

Figure 25. The location of zip code 97214. Map from P.S.U. Geography Department.

children's vitamins (ibicl., p. 354). Typified by low salaries, they are activist minded, Democratic-leaning and, apparently enjoy "hanging out at the local bar with a jukebox full of the Grateful Dead" (ibid., p. 355). (Two Hawthorne locations, appropriately, act as centers for Grateful Dead fans: The Barleymill Pub (1629) and The Third Eye (3950)!)

These 'tastes' are clearly generalized but they do help create an impression of what is meant by Sirigle City Blues. The transition that Portland's 97214 zip code area has undergone is noted: 
As the commurity shifted from stable ... families to younger, lowerincome singles * and more than a few gays - corner taverns were joined by used-l:ecord stores and organic food take-outs (ibid., p. 239).

However, during the 1980 s, it remained "a seedy area that attracts bikers to its Xrated video parlors ani panhandlers to its liquor stores." While few people were moving into the area, some newcomers were renovating their houses, but "not for gentrification, mind you, but to ward off a decline" (ibid., p. 240). Members of Single City Blues, as a whole, are characterized as "downscale singles who never gave a thought to being yuppies ... [living in] "inner-city neighborhoods ignored by gentrification" (ibid, p. 352).

While most of Hawthorne's patrons probably 'never gave a thought to being yuppies,' the area is no longer ignored by gentrification. It is possible that many Single City Blue:s zip codes have begun to experience gentrification since 1983, when the data used in the book were collected. Discrepancies are to be expected because Weiis makes generalizations about the country as a whole, rarely referring to any specific area. Nevertheless, The Clustering of America does confirm the character of the neighborhood and provides more evidence proving inner southeast Portland to be a bohemian neighborhood.

An academic study of the same area, by census tract rather than zip code, further elaborates on the character of the neighborhood. In discussing the existence of a spatially concentrated lesbian community, Adler and Brenner (1992) also characterized the neighborhood in which the concentration is found. The published study identifies neither the city studied, nor the location of the lesbian 
district within the city, but personal communication with Johanna Brenner, the coauthor, confirms that the "major concentration of lesbian households in a set of 11 contiguous inner city census tracts east of the central business district" is inner southeast Portland (ibid., p. 28).

It was found that "'property, family and wealth' are barriers to lesbian settlements, [while] counter-cultural neighbourhoods appear to be the most open." This was confirmed by:

the presence of counter-cultural institutions such as theatres, coffee shops, studios that present progressive/fringe entertainment, alternative businesses like food and bicycle repair coops, radical and feminist bookstores etc. (ibid., p. 29).

The character of Adler and Brenner's study area is also apparent from 1980 census data. Compared to the rest of Portland, the eleven 'lesbian' census tracts had a significantly lower proportions of owner occupied dwellings, and traditional families (married couples with children), and lower median rents (ibid.). There was also a high proportion of women in the neighborhood, particularly women living alone and heading households (ibid., p. 30).

For the lesbian community of Portland, this section of inner southeast constitutes a "hidden neighbourhood ... a neighbourhood that many people know about and move into to be with other lesbians. But the neighbourhood has a quasi-underground character; it is enfolded in a broader counter-cultural milieu and does not have its own public subculture and territory" (ibid., p.31, italics added). The alternative lifestyles associated with inner southeast are thus confirmed, as is the area's appeal to, and concentration of, lesbians. 


\section{CENSUS DATA}

The decennial census supplies a quantitative picture of intra-city variation and puts the Hawthorne area into context within the city of Portland. Hawthorne Boulevard is represented by seven tracts, five of which constitute the study area: tracts $12.01,12.02,13.01,13.02$, and 14 . These tracts comprise the area bounded by SE 16th and 49th Streets to the west and east, and SE Stark and Division Streets to the north and south.

The neighborhood's population is well-educated but retains its low-income status. Its socioeconomic character is confirmed by comparing median household income and the percentage of high school graduates in Hawthorne's five tracts with the city as a whole. Rising property values, often used as an indicator of gentrification (see Hamnett 1991; Schaffer and Smith 1986), provide little indication of the changes taking place in this case.

Census data (by tract) are mapped for the whole city, below. The city of Portland is defined here as 137 contiguous census tracts in Multnomah County. Hawthorne's tracts are compared with medians for the whole city, using 1990 data. The averages forming the basis of this comparison are the median values of these 137 tracts (Table III). All the maps in this section have an equal number of census tracts in each data class. Each category thus represents $25 \%$ of Portland's tracts, with two above and two below the median value.

According to the census, the median household income in Portland was $\$ 25,365$ in 1990 (Figure 26). Three of Hawthorne's tracts fall below this figure 
with median incomes of $\$ 18-24,000$. Two tracts, those immediately south of Hawthorne's concentration of revitalized businesses, have household incomes above the city median, both just over $\$ 28,000$.

\section{TABLE III}

\section{COMPARISON OF 1990 CENSUS DATA FOR HAWTHORNE'S FIVE TRACTS WITH CITY MEDIANS}

\begin{tabular}{|l|l:l|l|}
\hline Census Tract & $\begin{array}{l}\text { Median } \\
\text { Household } \\
\text { Income }\end{array}$ & $\begin{array}{l}\text { High School Graduates } \\
\text { (percentage of total } \\
\text { population) }\end{array}$ & $\begin{array}{l}\text { Median } \\
\text { House } \\
\text { Value }\end{array}$ \\
\hline 12.01 & $\$ 18,677$ & $62.3 \%$ & $\$ 55,000$ \\
\hdashline 12.02 & $\$ 28,561$ & $62.9 \%$ & $\$ 72,500$ \\
\hdashline 13.01 & $\$ 20,890$ & $56.9 \%$ & $\$ 45,500$ \\
\hdashline 13.02 & $\$ 28,166$ & $57.3 \%$ & $\$ 50,800$ \\
\hdashline 14 & $\$ 23,855$ & $58.8 \%$ & $\$ 48,100$ \\
\hdashline City Median & $\$ 25,365$ & $56.9 \%$ & $\$ 55,250$ \\
\hline
\end{tabular}

This relatively low household income belies a rate of increase, since 1980 , above the city median increase (Figure 27 ). In ten years the city's median household income rose by $65.8 \%$; Hawthorne's tracts increased between $68.3 \%$ and $81.7 \%$. Thus, while the district's median household income remains low in relation to the rest of the city, it has recently experienced large gains. This trend probably indicates the in-migration of wealthier residents.

In spite of the area's low income level, its residents are well-educated. Figure 28 shows that all of Hawthorne's tracts have a high percentage of high school graduates among their population. (The figures refer to people over 


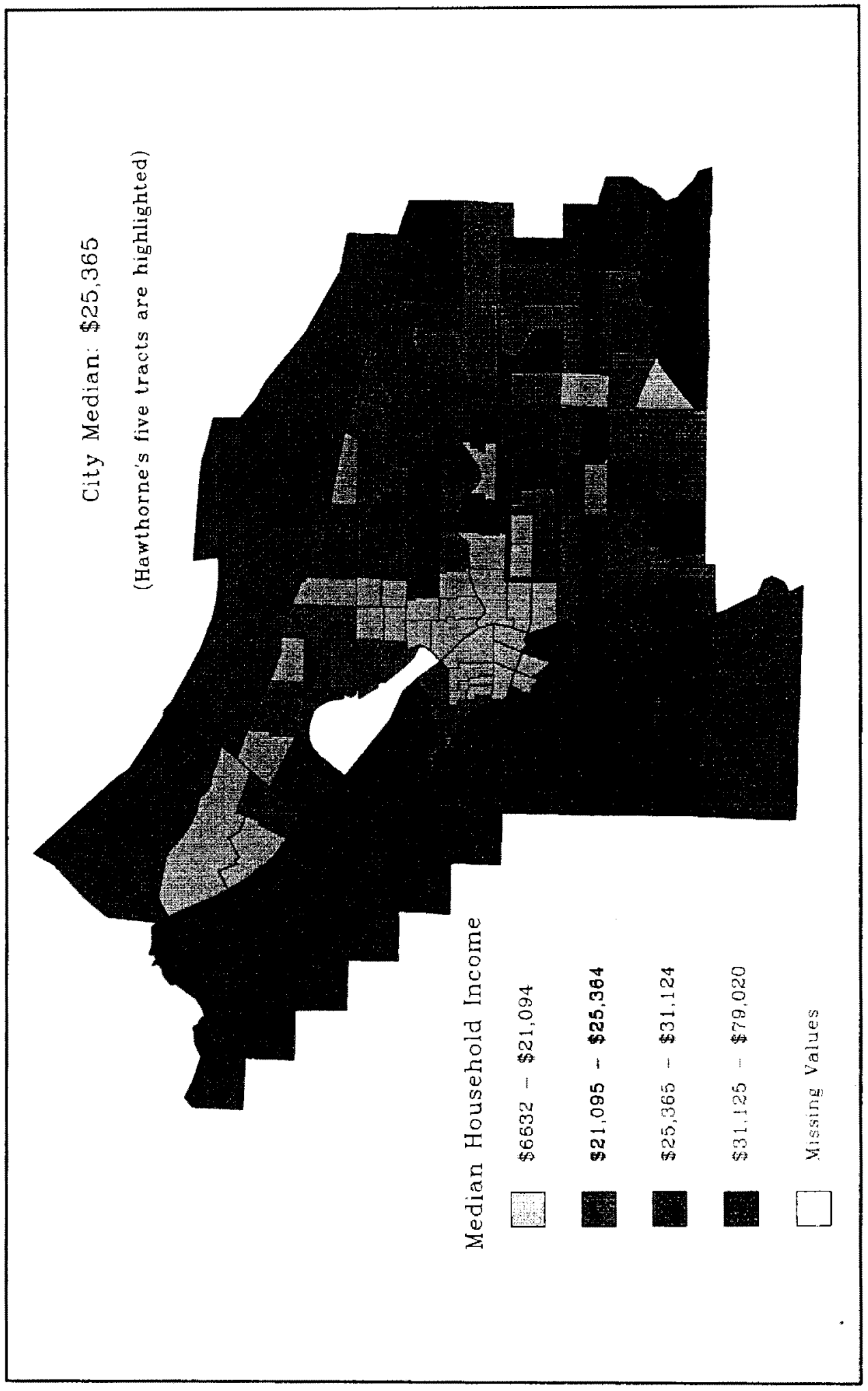

車

을

음

농

ث્

อ

它

응

든

䓀

들

园

$\stackrel{\circlearrowright}{\Sigma}$

ํํํ롱 


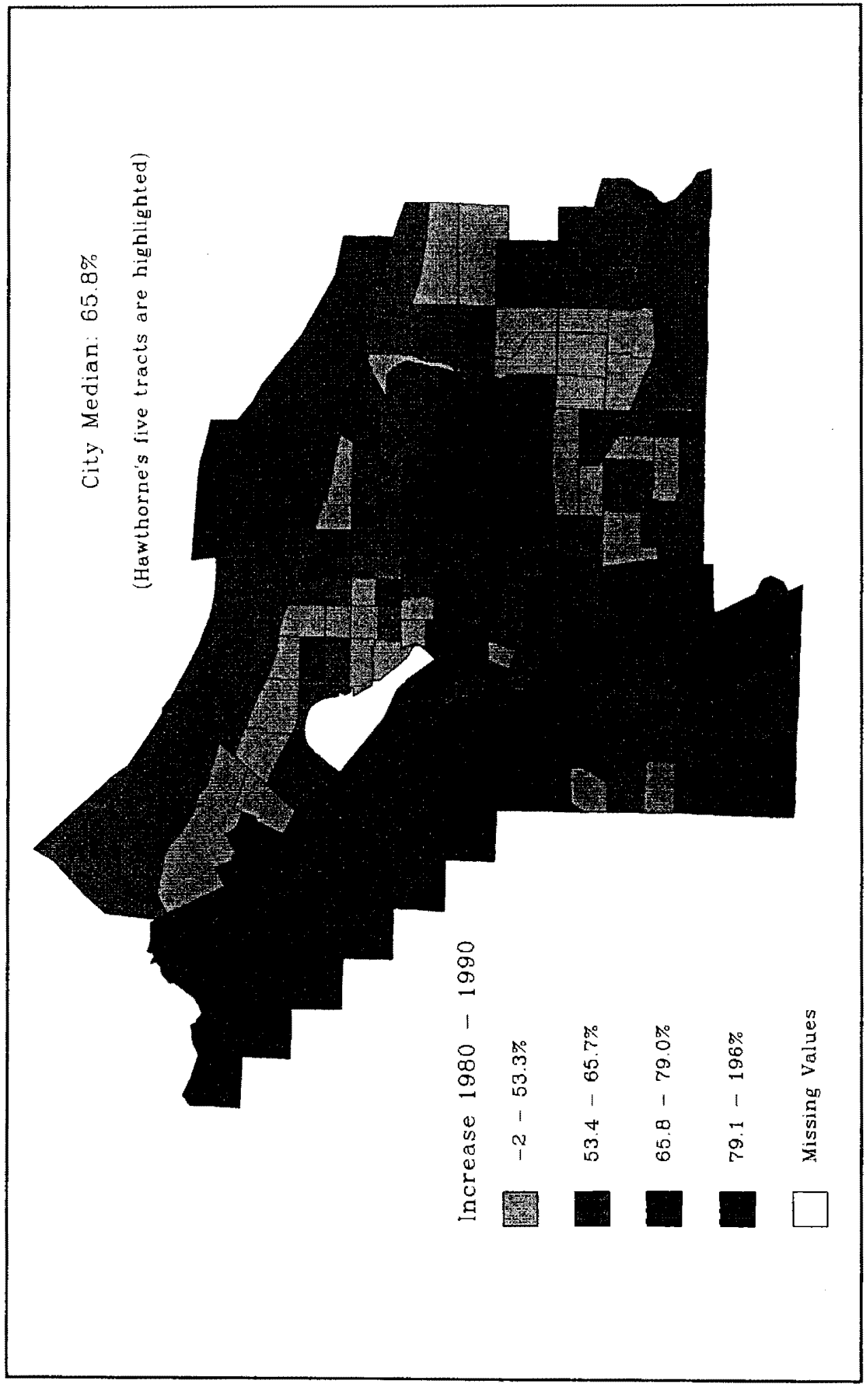

ต

a

통

唄

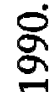

9

응

苞

ลำ

용

믕

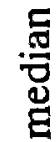

$\Xi$

通

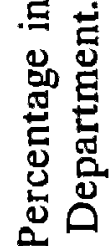

숴롬 
twenty-five years old.) While Portland's median is $58.9 \%$, Hawthorne's ranges from $56.9 \%$ to $62.9 \%$. Four out of the five selected tracts have undergone increases in educational attainment greater than much of the city, since 1980 . The Hawthorne area was above average in 1980 , too.

Median residential property values in the Hawthorne area are below those for the city as a whole (Figure 29), but increased by between $3.4 \%$ and $18.8 \%$ from 1980 to 1990 . The 1990 city median of $\$ 55,250$, up only $4.6 \%$ since 1980 , reflects the recession of the early 1980 s. The degree to which external forces dominated property values during the period prevents housing values from being an effective indicator of neighborhood change.

The latest census is not current enough to reflect dramatic increases in property values that have occurred in inner southeast Portland in the last couple of years. House prices around Hawthorne have increased by at least $25 \%$ in the past year (Southeast Examiner May 1992). Change has been apparent in the business district for many years, yet it has only just begun to manifest itself in the surrounding neighborhoods. Commercial gentrification has preceded residential upgrading.

The census thus confirms the character of the residential neighborhoods surrounding Hawthorne Boulevard. The five census tracts adjacent to the commercial district have a relatively low-income but well-educated population. This substantiates the assertion that the area "def[ies] ... the usual link between education and affluence" (Weiss 1988, p. 352). 


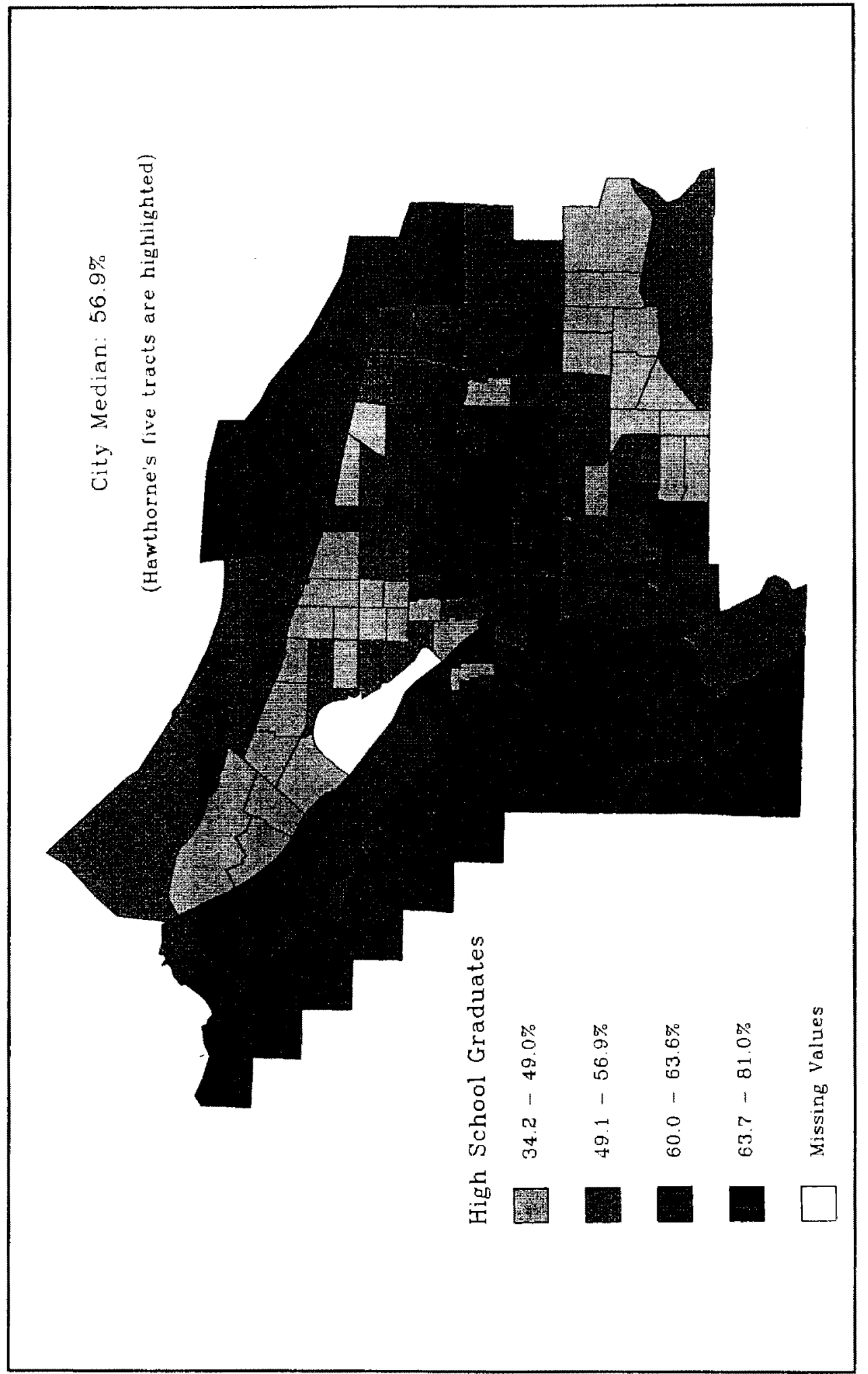

D

E

욜

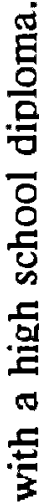

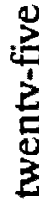

a

岁

음

范

$\stackrel{0}{0}$

莡

ญ

ธั่

에름

늡 몽

병워 


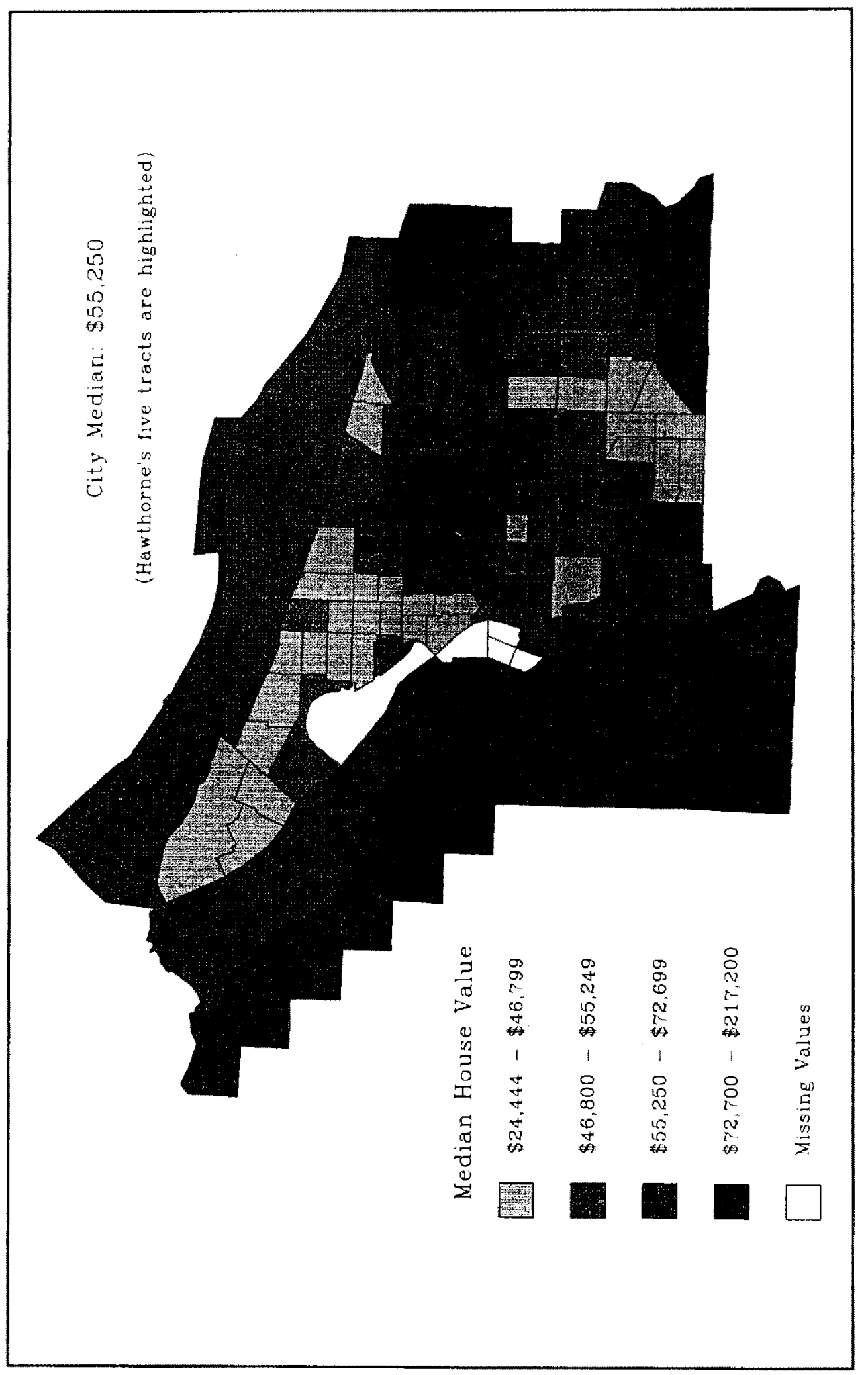

2

통

용

呑

몸

돈

농

志

궁

כ

ฮี

몽

㲾 
However, changes wrought by gentrification are not yet discernible from the census. Compared to the whole city, increases in housing values near Hawthorne are not unusual. More recent data would show significant increases since 1990. Residential upgrading is following the lead of the commercial district: the business district made a dramatic leap forward in 1991, and it can be expected that the neighborhoods will have a similar experience in years to come. 


\section{CHAPTER V}

\section{THE SIGNIFICANCE OF HAWTHORNE'S REVITALIZATION}

The transformation of Hawthorne from a declining service strip to a vibrant retail district has created a place which serves the whole city and beyond, while still reflecting the social makeup of its surrounding neighborhoods. Through a combination of coincidence, concerted effort, and timing, Hawthorne has become a distinctive place within Portland. The street is proud of its revitalization and stresses its uniqueness, yet underlying the revitalization of Hawthorne are several trends widely influencing central city neighborhoods throughout North America and Western Europe.

This chapter looks at a number of these trends, placing Hawthorne within the context of broader alterations to the social organization of urban space. To illustrate this, four closely related topics are discussed. These are: 1) gentrification and the rejection of suburbia; 2) postmodernism and new consumption styles; 3 ) the role of women in gentrification; and 4) the development of subcultural neighborhoods and business districts.

These processes are interlinked because of the complex nature of gentrification. It is both indicative of changes in societal structure, and instrumental in changing the social, economic and physical makeup of central city neighborhoods. When put in context, Hawthorne appears not as a unique district 
but, rather, as just one manifestation of a changing society.

\section{GENTRIFICATION}

Gentrification, the underlying tenet of this thesis, is the most important national trend affecting Hawthorne. It has been the clearest manifestation of the shift towards postmodernity (discussed later in this section), illustrating a reversal of previous housing trends and the increasing popularity of human scale architecture and urban design.

Studies have examined almost every aspect of residential upgrading in numerous cities while virtually ignoring concomitant commercial improvements. This bias may be due to the greater impact of residential neighborhoods on urban restructuring (because of their larger spatial extent), and the ready availability of socio-economic data from the decennial census. However, commercial districts are more conspicuous than their surrounding neighborhoods and "can perform the symbolic function of encapsulating a neighborhood's image" (Henig 1982, p. 50). Retail activities are a clear indicator of societal change.

Upgrading of the retail sector has not gone unnoticed in gentrification and many studies do mention the transformation of neighborhood stores into specialty shops and restaurants. Yet, in most cases, the reference to commercial change is fleeting. Authors have noted a rapid increase in the number of specialty stores, particularly food and clothing (Ley 1980, p. 245); the "displacement of communityservice-oriented businesses by the proliferating restaurants . . . bars, boutiques, 
and trendy specialty shops" (Godfrey 1988, p. 192); the replacement of "Ma-andPa" type businesses with art galleries and antique shops (Cybriwsky 1978, p. 29); and, even, a proliferation of "cinema noir Tex-Mex diners; boutique malls in modes of victorian elegance and industrial kitsch" (Caulfield 1989, p. 626, italics in original). David Ley refers to this transformation as "a retail cycle from junk to art to vogue" (Ley 1988, p. 45).

While acknowledging its occurrence and the form it is taking, writers have paid little heed to retail revitalization as a process worthy of study in its own right. In lieu of commercial analyses, this study incorporates some aspects of the residential gentrification literature that can be applied to commercial change and provide a setting for this examination of Hawthorne.

Explanations for gentrification fall roughly into two camps: the cultural (consumption-oriented) and the economic (production-oriented). The former attributes the reclamation of central cities to a combination of demographic shifts and societal desires, the creation of the new middle class, and a self-focused urban culture (Ley 1980). The latter sees it as the result of economic opportunities being taken by profit-seekers (Smith 1987). However, the complexity of gentrification makes it almost impossible to isolate the contributing variables and trace all their impacts.

This "inherently problematic nexus of culture and economy" (Bondi 1990, p. 195 ) is effectively summarized by Jon Caulfield's discussion of gentrification as a displacement process (Caulfield 1989). The structuralist (economic-production) 
explanation regards gentrification as a two stage process in which:

Bohemians and artists, acting as a Trojan Horse for property interests and municipal boosters who have paved their way, move into a debilitated neighborhood; then, as real estate values influenced by the avant-garde's presence - quickly inflate, developers and affluent in-movers supplant their unwitting colonists (ibid., p. 619).

In contrast, a three stage progression is advocated by the non-structuralist (cultural-consumption) argument. This side of the debate sees gentrification as: initiated by movement into a neighborhood of economically or culturally marginal middle-class resettlers drawn by cheap space, local colour and tolerance for difference; is then continued by more mainstream middle-class in-movement oriented toward neighborhood fashionability and security of investment; and is finally concluded by a conjuncture of inflating prices, still more affluent arrivals, and emerging neighborhood elite status (ibid., p. 618-9, italics added).

In both cases the result is the same, but the interpretation of process is very different.

These two ideas are the polar positions in a complex debate that has occupied urban geographers for much of the last two decades (Hamnett 1991). The phenomenon of gentrification can be fully explained only by considering all sides of the debate: the economic, the social, the cultural, and the demographic. Economic explanations, however, will be peripheral to this examination of the factors underlying gentrification because broad macro-scale trends - those best explained by economic arguments - are, on a local scale, moderated by individual neighborhoods (Godfrey 1988). Indeed: 
[t]he broad economic restructuring of the American economy, as well as the evolution of the land market, explain in a general sense the metropolitan areas most affected by gentrification. But on a local level, we need to look at the social dynamics of community formation and neighborhood change (ibid., p. 177).

Assuming central cities to be replete with economic opportunities for reusing underused, run-down buildings (both residential and commercial) the crucial issue is to determine the origins of this new middle class demand and why it is fulfilled in the inner city (Hamnett 1991, p. 184). There are many reasons for this "so-called return of the middle class to the central city" (Ley 1988), including changes in employment, demographics, and aesthetic preferences.

The significance of gentrification - taken here to mean the upgrading of central city areas by a population that is younger and wealthier than an area's existing inhabitants - lies in it being the first distinct shift away from the mass suburbanization which dominated urban population movements until recently. The association between wealth and the ability to live at an ever-increasing distance from the central city has been a fact of urban life since the Industrial Revolution, but widespread access to private transportation and the desire for low density single-family housing led to massive population deconcentration in the postwar era.

Occurring nationwide since the 1970s, the causes of a slight, but significant, reversal of this seemingly inexorable suburbanization is a matter of wide debate and disagreement (see Hamnett 1991 for a detailed overview of the major issues). Most studies attribute this process to an influx of young, white, childless 
professionals, attracted by the cheap and potentially attractive housing stock with easy access to downtown. High-paying downtown jobs and delayed child-bearing enable them to maintain a large discretionary income and live beyond the means of their suburban peers. This new urban lifestyle is distinctive in its "conspicuous consumption of quality goods and services" (Mills 1988, p. 181). This is apparent in the landscape: art galleries, ethnic restaurants and specialty stores proliferate in gentrifying districts.

This influx of upscale shops displaces existing, lower order, stores. Convenience stores go out of business as rents increase and the local clientele changes. Liz Bondi sees gentrification as an "inherently divisive" process in which "profit-making for some is impoverishment for others; the 'lifestyle choices' of some deny those of others" (Bondi 1990, p. 191-2). Yet displacement may not have as severe an effect on businesses as it does housing. Henig (1982, p. 59) sees business failure (notoriously common among small businesses) as indicative of an inability, or unwillingness, to adapt to the changing circumstances in gentrifying areas. In fact, "we might reasonably conclude that gentrification only accelerates the weeding out of non-competitive and inefficient operations" (ibid.).

In the residential realm, an influx of wealthy individuals into working-class districts rapidly increases the demand for housing in the area and pushes rents beyond the means of the original inhabitants. This displacement of working class communities is what has given gentrification its negative connotations. While displacement is mentioned in many residential studies (Schaffer and Smith 1986; 
Bondi 1990), most authors concentrate on the causes of gentrification and its positive effects.

\section{POSTMODERN SOCIETY AND CONSUMPTION}

Explanations for gentrification must start with societal restructuring (Hamnett 1991). The term 'postmodern' is frequently used to describe a newly emerging society of which gentrification is the clearest manifestation in urban space. The concept of postmodernism originated in the field of architecture but has been adapted to cover widespread societal trends towards a leisure-based, consumption-oriented society with an increasing emphasis on aesthetics and selffulfillment.

How these two are connected is not immediately apparent, but, in geography, the term has evolved from its original architectural connotations. Thus:

Post-modern architecture is distinguished by its combination of styles, by its preference for the vernacular over the academic, and by its rejection of strict historicism. Post-modernism tends towards the hybrid, with a penchant for parody and kitsch, and a determined irreverence towards the canons of good taste (Jackson 1989, p. 175).

What was initially "a reaction against elitism and utopianism" has become, both in architecture and in society, "deeply implicated in consumption ideology" (Mills 1988, p. 176). What was originally intended as a move away from the prestige associated with modernist architecture, has evolved into a style which is increasingly expensive and fashionable, putting it out of the reach of most people. 
Similarly,

at its best ... postmodern forms represent an architecture of everyday life ... At its worst, postmodernism caters in a trivial manner to the culture of consumption in advanced nations (Ley 1985, p. 419).

Gentrification straddles this dichotomy. It symbolizes a return to traditional neighborhoods, but a return that eventually prices out all but an elite.

Postmodern consumption patterns are closely related to economic shifts towards 'postindustrialism.' (Both terms refer to the same process but where postmodernism concentrates on the cultural aspects of societal transformation, postindustrialism is predominantly concerned with economic shifts.) The concept of postindustrialism - that which is beyond industrialism - is less generally accepted than its predecessor because American society still has an industrial basis and will continue to for the foreseeable future. However, just as we are not and probably never will be post-agrarian, we are unlikely to ever be fully postindustrial; yet as fewer people rely on manufacturing employment, the notion of an industrial society seems obsolete.

As society shifts towards the production of information rather than the production of goods, an increasing number of people find white-collar employment downtown (Bell 1973, Clark 1985). There is "a causal link between the production of a new professional and managerial labour force, the cultural and consumption characteristics of part of that group, and the creation of potential gentrifiers" (Hamnett 1991, p. 184). All are manifestations of a postindustrial society.

Observers have noticed a correlation between gentrification and the 
amount of downtown office space (Ley 1988, p. 259) and, similarly, among large cities that experienced gentrification in the late 1960s, one-quarter of central city census tracts had education levels above the metropolitan median (Lipton 1977, cited in Ley 1988, p. 259). These well-educated office workers are those most likely to become gentrifiers.

Simultaneously, demographic shifts and changing attitudes have influenced the residential decisions of households. Increasing numbers of women in the labor force, postponed marriages, people living alone, and delayed child-bearing have all added to the demand for small housing units close to downtown. These trends are accentuated by the increased demand for housing which comes from the maturation of the baby boom generation. That "a significant proportion of them [wealthy, childless, baby boomers] seem to have opted for inner city residence in those cities where city centre social and cultural facilities exist" has given rise to gentrification (Hamnett 1991, p. 186-7).

Those most associated with this new lifestyle are young, urban professionals - the yuppies - who constitute the most visible urban subculture of recent years.

Ley (1980, p. 243) describes this "class in emergence" thus:

as a group they are highly educated ... younger members in particular exhibit a high degree of social if not political liberalism, and have plural life goals placing a higher premium on selffulfillment as a major career objective than any other occupational category ... Their lifestyle is commonly consumption and status oriented in the pursuit of self-actualization.

This liberal, elite sector of society emerged from a "cultural resurgence ... characterized by its promotion of alternative values which emphasize the realm of 
experience, man's [sic] emotional, spiritual, and aesthetic nature" (Ley 1980, p.

242). This outlook grew with the counter-culture movement of the 1960 s and has now permeated wider society. Indeed "the sensuous and aesthetic philosophy released by the counter-culture has been appropriated ... by the growing numbers of North America's leisure class" (ibid.). The appeal of central city residence comes from changes in personal desires and expectations which parallel changes in the economic and organizational aspects of late twentieth century society. Yet the existence of a social group attracted to the central city does not explain why certain neighborhoods undergo gentrification while others do not.

Physical attractiveness has a great deal to do with where gentrification begins in a city. Ley (1988, p. 163) notes that "[l]andscape symbols of historical association, architectural heritage, or environmental amenity have encouraged gentrification." These distinctive features are what attracts the initial pioneers, while the presence of the pioneers themselves and the 'funky ambience' (Godfrey 1988) of incipient revitalization is often enough to attract more people.

Frequently "young couples from the arts, design and teaching professions" (Knox 1982, p. 136) move into run-down areas looking for cheap housing. These pioneers upgrade poorly maintained areas and are:

given credit with their friends for going to live among the working classes, thus generating a 'trendiness' which soon ensures that the pioneers acquire a substantial number of middle-class neighbours of similarly adventurous and liberal outlook to themselves (ibid.).

Once an area has gained a distinct character, it usually retains its reputation (Godfrey 1988, p. 46). As more central city districts are becoming gentrified, the 
process has now moved on into:

neighborhoods where the original housing was built for artisans rather than the middle classes [not just Victorians and brownstones] ... with a potential environmental and aesthetic appeal - 'a raffish chic' - which attracts the inverted snobbery of the pioneering young professionals (Knox 1982, p. 136).

As prime sites are taken, the process diffuses down the locational and social scale. It is these secondary sites of gentrification, like Hawthorne, which seem less likely to achieve fully gentrified status associated with yuppie culture and conspicuous consumption.

These changing patterns of consumption and commerce underpin postmodern society. Indeed, while gentrification has been studied almost entirely within the residential realm, postmodernism is generally described in terms of consumption styles. Academic emphasis has been on how postmodern residential landscapes look and on the types of goods consumed. Thus the nature of consumption, rather than the ways in which postmodern commercial landscapes look or function, has dominated cultural studies of this new strata of society. New lifestyles and consumption pattern are becoming so widespread that:

We can enter a taxi in almost any large, American city and confidently ask to be taken to the local renewed nineteenth century warehouse district where we find the expected decor of macrame, butcher block, and exposed brick known in the trade as "fern bar" style (Riley 1980, p. 6).

The development of these postmodern landscapes can be seen as a third phase of twentieth century urban design (Relph 1987, p. 239), following the premodern and the modern. Commercial streets remained much as they had been 
for centuries until the modernist era of the 1940s brought a shift of emphasis from pedestrian to motorist, and the development of a rational, austere architectural style designed to be appreciated only at high speeds (ibid., p. 239). More recently, the postmodern era has heralded a return to a pedestrian orientation which rejects the auto-dominance of modern architecture (ibid., p. 241). Relph notes that these postmodern townscapes "are the product of the combined effects of heritage preservation, urban design, post-modern architecture, gentrification both residential and commercial, and community planning" (ibid., p. 252, italics added), and it is into this final category that Hawthorne falls.

The predominant character of these most recent townscapes is quaintness visible in store names, a medieval scale, and textured surfaces. While Hawthorne is less contrived than are many postmodern environments, it embodies some of the required elements of a postmodern street: enclosures, passageways, courtyards, canopies, continuities between inside and outside, few right angles, and deflected views (ibid., p. 253). Relph coins the term 'quaintspace' to describe this "undeniably fashionable" landscape (ibid., p. 255).

Underpinned by the style and scale of the early twentieth century, recent revitalization has pushed Hawthorne beyond the traditional image of a neighborhood Main Street into the "commercial chicness" (ibid.) of the postmodern. It fits Relph's description yet further, in that: 
many post-modern townscapes are filled with more or less subtle indications of affluence. Here consumption is not gauche and flashy, perhaps because the heritage styles and quaintness tend to restrict the possibilities for ostentation, but more probably because postmodernism aspires to be the setting for a discriminating class of consumer (ibid., p. 255).

\section{WOMEN AND GENTRIFICATION}

One aspect of the inner city revitalization particularly relevant to the evolution of Hawthorne's image is the relationship between gentrification and gender. Gentrification has been described as "an expression of changing gender divisions" (Bondi 1992, p. 157) and "in large part a result of the breakdown of the patriarchal household" (Markusen 1981, p. 32). Certainly, changes in family structure, combined with more women attaining managerial employment, has created "small, affluent households capable of paying high prices for sought after housing" (Bondi 1990, p. 192).

Rejection of a suburban lifestyle is particularly germane to the notion of gentrification and changing gender roles because:

gentrification stands in opposition to both the rigid separation of city and suburb, and to the internal homogeneity and monotony of sprawling suburbia. Notwithstanding its economic rationale, this rejection of suburbia is also a rejection of the notion of separate spheres for women and men, gentrification offering less polarized and more diversified images (Bondi 1990, p. 164).

Gentrification is symbolic of women turning their backs on their suburban existence and joining men in the central city. For career-oriented women: 
inner-city neighbourhoods appear to provide a more appropriate environment than suburbia in which to combine professional employment with non-traditional household arrangements and thereby to develop alternative definitions of femininity (Bondi 1992, p. 163).

No work has been done which specifically addresses the role of lesbians in gentrification. Several studies, discussed below, associate gay men with the early stages of gentrification. Women, however, are less able to choose where they live than men because they tend to have less money, are more likely to have children and are more susceptible to physical violence (Adler and Brenner 1992, p. 32). Economic disadvantages experienced by many single women make them particularly vulnerable to displacement from gentrifying neighborhoods (Bondi $1990,1992)$.

One author has suggested that the appeal of gentrified environments is their androgyny (Mills 1988, p. 186). In turning against the masculine architecture of the modernist era, new landscapes are being developed. Postmodern landscapes use "bedroom colours and sensuous curves on external walls" (Gibson 1984, cited in Mills 1988, p. 186). Mills suggests this emerging style illustrates a shift in identities and, possibly, explains why postmodern environments appeal to women and gays. While this connection may be coincidental, Liz Bondi has also noted "postmodernism has acquired feminine connotations" (1992, p. 165). 


\section{SUBCULTURAL NEIGHBORHOODS}

One further aspect of urban social structure which helps explain the character of Hawthorne is the evolution of residential neighborhoods formed by distinct social groups. These were most apparent during the 1960 s when "hippy neighborhoods" developed in Greenwich Village, New York; Old Town, Chicago; Yorkville, Toronto; and Haight-Ashbury, San Francisco (Ley 1988). HaightAshbury remains the prototype counter-culture neighborhood.

Nonconformist neighborhoods, formed by the "conscious group rejection of selected cultural trappings of the American middle class" (Godfrey 1988, p. 216) attract people sharing a similar lifestyle rather than social class or family stage as is more common. This is becoming increasingly common as:

many nonconformist groups - such as the counter-culture, feminists, homosexuals, political radicals, students and artistic movements, and so on - have attained the requisite sense of solidarity, social cohesion, and structured relationships underlying most concepts of community (Godfrey 1988, p. 32-3).

Once these prerequisites for a spatially-defined community exist, central city neighborhoods (as opposed to suburbia) are the ideal location because "these mileux enable a diversification of ways of carrying out reproductive work; they offer a concentration of supportive services; and they often have a tolerant ambience" (Rose 1989; 131, cited in Bondi 1990).

The clearest examples of spatial concentrations of a lifestyle group come from studies of the gay male community. Such communities develop "'by choice' through their disagreement with the nativist suburban culture" (Vance, cited in 
Godfrey 1988, p. 43). The congregation of gays in identifiable neighborhoods has been associated with central city revitalization. The role of the gay community in upgrading central neighborhoods has been well documented (Levine 1979; Castells and Murphy 1982). Godfrey (1988, p. 191) notes that "homosexuals are disproportionately represented in the early stages of gentrification" and, similarly, that when gay neighborhoods gentrify they, like other areas, retain their social reputation and what were once gay counter-culture areas become more middleclass with the influx of 'guppies,' the yuppies' gay counterparts (ibid., p.122).

Studies of gay neighborhoods have been limited almost exclusively to communities created by gay men. While lesbians may be present in gay communities, it is men who "dominate their distinct subcultures, their businesses and their residences, their street life and their political activities" (Adler and Brenner 1992, p. 24). Castells (1983) suggests that lesbians are 'placeless' and that their social networks are not spatially-based.

However, Adler and Brenner claim that lesbians do form spatial communities. These enclaves are less apparent that gay male communities because of gender differences in access to capital and the means to control space. In their connections to places, lesbians differ from gay men in four important ways. Women have less access to capital, are more likely to choose a location with children in mind, are more vulnerable to violence, and are less interested in place-based politics than in wider issues. These elements, which clearly apply to heterosexual women as well, "may limit lesbians' interest in or ability to create the 
kind of vibrant street culture that makes an urban community" (ibid., p. 32).

To describe the lesbian 'ghetto,' Adler and Brenner use the terms "semivisible lesbian urban space" (p. 25) and "the hidden neighbourhood" (p. 31). While financial, demographic, societal and political issues deter lesbians from creating conspicuous residential districts "there is ... a neighbourhood that many people know about and move into to be with other lesbians. But the neighbourhood has a quasi-underground character ... and does not have its own public subculture and territory" (ibid., p. 31). On Hawthorne, while the lesbian presence does not dominate the district and the business community, there is a concentration of businesses openly supportive of the lesbian community.

Indeed, evidence of subcultural neighborhoods is frequently apparent in the "characteristics of businesses, social services and other gathering spots, and these provide a subcultural refuge for ... unconventional groups in the city" (Godfrey $1988, \mathrm{p} .44-5)$. Related to the development of lifestyle-based neighborhoods is the adaptation of old neighborhood shopping areas to serve aspatial markets based on 'lifestyle' communities (Jones and Simmons 1987, p. 51). Indeed, "local lifestyle shopping areas act like downtowns for community members whose residences may be scattered across the entire urban area" (ibid.). Applying this notion to Hawthorne, the street can be seen as a focus for, among others, the lesbian community and the bohemian elements of Portland society.

Districts providing a cultural center for a disparate group are usually associated with ethnic communities but the increasing variation in urban lifestyles 
sees the emergence of new lifestyle-based foci. In both cases, community members "prefer stores run by group members . . . that cluster together to form a community focus: a meeting ground where members of the lifestyle group can meet, talk and show off" (Jones and Simmons 1987, p. 49-51).

Brian Godfrey (1988) provides an effective comparison of ethnic and lifestyle neighborhoods. While both serve the same social function, members of ethnic groups are less spatially and socially mobile, and "oppositional areas provide evidence of more rapid subcultural intensification and succession" (Godfrey 1988, p. 214). There are several reasons why those living alternative lifestyles are not as spatially bound as are other groups: they tend to have more flexible households, fewer constraints, a conditional affluence because they are less inclined to spend money on traditional pursuits, and can select appealing areas in which to live because socio-economic or functional factors are not important aspects in their choice of location (ibid., p. 215).

The existence of such specialty districts is well known, yet few authors have elaborated on the characteristics of such places. Although the small number of studies that do exist fall within the realm of gentrification studies, the gentrification literature as a whole pays scant attention to the commercial sector. However, a few commercially-focused studies do illustrate how Hawthorne-like processes are affecting many retail districts.

Closest to Portland and, perhaps, closest to the character of Hawthome is David Hodge's examination of Capitol Hill in Seattle (Hodge 1980). Many 
aspects of the revitalization that has taken place on Broadway, the commercial core of Capitol Hill, parallel the experience of Hawthorne. The district experienced decline in 1960s, and developed an image as "a lower-class 'Bohemian' neighborhood where all types of behavior were observed and for the most part tolerated" (Hodge 1980, p. 196).

Hodge attributes Capitol's Hill's turning point - when the declining neighborhood commercial strip began to show signs of improvement - to the opening of a chic restaurant in 1973. This is similar to Hawthorne's experience of revitalization being spearheaded by Pastaworks and Bread and Ink. In Capitol Hill, as on Hawthorne, neighborhood shops were slowly replaced by stores with a wider market area.

Furthermore, both Broadway and Hawthorne underwent revitalization before their surrounding neighborhoods. On Broadway, "[t]he commercial renaissance triggered by the opening of Boondocks [the chic restaurant] led to major changes in the residential community as well ... [and] the area surrounding the Broadway district has ... responded strongly to the changing image of the neighborhood" (ibid., p. 197). Revitalization thus improved the retail strip and attracted people back into the once-declining residential areas.

Capitol Hill is now a prestigious central city neighborhood which has managed to retain its "reputation for social tolerance and diversity of lifestyles" (ibid.). Today, Broadway is an example of what Hawthorne could become. It still has a few used books and record shops, but these are not as dominant a presence 
as they are on Hawthorne; more obvious are the galleries and the proliferation of ethnic restaurants. Broadway, like Hawthorne, is also home to a Macheesmo Mouse restaurant, a loose bead store and an all-cotton clothing store. However many shops tend towards ostentation, giving the area the air of higher-class bohemia than exists on Hawthorne.

Nationwide, retail environments are adapting to changes within society, reflecting the emergence of new needs and tastes. Jones and Simmons (1987) identified the impact of nine societal trends on retail structure. Table IV illustrates how demographic, economic and technological changes influence retailing patterns. Within the city, reduced household size, neighborhood transition, and downtown social segmentation (e.g. gentrification) are producing small, specialized retail clusters (Jones and Simmons 1987, p. 218, 394). At the same time, increases in average income and leisure time have transformed shopping into a recreational activity. These widespread processes are the same as those that underlie residential gentrification.

Most of the factors emphasized in Table IV relate to the increasing specialization of retailing activities. Simultaneously, other factors are creating larger out-of-town shopping centers where having fun is an important part of spending money. This trend is epitomized by the recent opening of the Mall of America in Bloomington, Minnesota and, in suburban Portland, the Incredible Universe, a vast home electronics store. This developing dichotomy between small-scale, specialized operations and monolithic malls is creating a polarized 
TABLE IV

RETAIL CHANGE WITHIN THE METROPOLIS

\begin{tabular}{|c|c|c|}
\hline \multicolumn{2}{|c|}{ SOURCE OF CHANGE } & \multirow{2}{*}{$\begin{array}{l}\text { RESPONSE OF RETAIL STRUCTURE } \\
\text { Almost entirely suburban; favors suburban } \\
\text { malls } \\
\text { Growth accelerates all change }\end{array}$} \\
\hline $\begin{array}{l}\text { Residential } \\
\text { pattern }\end{array}$ & Growth & \\
\hline & Declining household size & Favors smaller, more convenient facilities \\
\hline & Neighborhood transition & Alters the form of specialization \\
\hline & Downtown social segmentation & Specialization in older strips \\
\hline \multirow[t]{2}{*}{ Income } & Increase & $\begin{array}{l}\text { Throughout metropolitan region, increasing } \\
\text { retail space everywhere } \\
\text { Favors specialization, downtown shopping }\end{array}$ \\
\hline & Leisure & $\begin{array}{l}\text { Weekend, recreation-linked shopping } \\
\text { Tourism, favors specialized shopping }\end{array}$ \\
\hline \multirow[t]{2}{*}{ Mobility } & Increase & Permits specialization, increased scale \\
\hline & Type (eg. car or transit) & $\begin{array}{l}\text { Transit favors downtown, car favors } \\
\text { suburban malls }\end{array}$ \\
\hline Technology & Automation & $\begin{array}{l}\text { Increased scale } \\
\text { Accelerates depreciation, favors new } \\
\text { investment } \\
\text { Deskilling of labor force }\end{array}$ \\
\hline
\end{tabular}

Notes: Adapted from Jones and Simmons 1987, p. 218.

Factors relevant to Hawthorne are shown in bold type. 
retail structure (Jones and Simmons 1987, p. 398). The middle ground is disappearing as neighborhood stores are replaced by either impersonal, suburban malls or upgraded central city specialty districts like Portland's Hawthorne and NW 23rd.

Henig (1982) identifies factors of residential gentrification which have a bearing on neighborhood businesses (see Table V). An influx of wealthy and childless gentrifiers changes the demand for goods and services such that "[a]ccessibility may give way to luxury, convenience to chic, as the criteria for customer acceptance" (ibid., p. 51). Establishments particularly susceptible to losing customers through gentrification include barbers, locksmiths, appliance stores and dry cleaners (ibid., p. 56). These neighborhood-based service functions tend to be replaced by "gourmet food outlets, expensive restaurants, health food, tennis and jogging equipment, and high fashion clothing" (ibid., p. 50).

\section{SUMMARY}

Revitalization on Hawthorne exemplifies many national trends, the most distinct of which is gentrification. Commercial gentrification has been largely overlooked in academic work, but it strongly resembles residential gentrification. Revitalization on Hawthorne preceded nearby residential improvements, attracting new groups of people into the area. Many cases of gentrification start with a concentration of non-traditional households in central city districts, often in areas experiencing decline. Low rents and appealing buildings attract subcultural groups 
TABLE V

\section{THE IMPACT OF RESIDENTLAL GENTRIFICATION ON RETAILING DEMAND}

\begin{tabular}{|l|l|}
\hline GENTRIFICATION BRINGS ABOUT: & LEADING TO: \\
\hline Level of Demand: & Decreasing Patronage for: \\
Decline of population & High volume outlets \\
Increase in per capita purchasing power & Elderly oriented businesses \\
Mobility of markets (attractiveness to & Children oriented businesses \\
outsiders; greater options for insiders) & Laundromats \\
& Convenience stores \\
\hline Type of Demand: & Increased patronage for: \\
Changing needs & Luxury goods \\
Changing tastes & Gourmet food shops \\
& Wine and cheese stores \\
& Restaurants \\
& Nightspots \\
& Boutiques \\
\hline
\end{tabular}

Note: Adapted from Henig 1982, p. 51. 
"opposed to the pursuit of material affluence" (Godfrey 1988, p. 187). Artists, bohemians, and gays frequently form a large part of this alternative community. When such groups concentrate in distinct areas, the neighborhood they create attracts other people, usually more conventional than the original inmigrants. In this way, an area progresses from being a focus for alternative lifestyle groups to a trendy, middle-class neighborhood. This influx of wealthier people eventually displaces earlier inhabitants and destroys the diversity which provided the initial attraction.

Hawthorne has recently begun the process of gentrification. The increasing attractiveness of the district is gradually altering the clientele and displacing local services. However, its atmosphere is still predominantly bohemian and it serves as a 'lifestyle' shopping district for several subcultural groups in the city. Hawthorne largely reflects the character of its neighborhood but, as the neighborhood begins to appeal to wealthier people, so the stores on Hawthorne will change. The current dichotomies visible in the makeup of the district's business mix and image are signs of the various trends influencing the district. 


\section{CHAPTER VI}

\section{CONCLUSIONS}

I have demonstrated that Southeast Hawthorne Boulevard has undergone a major transformation which reversed its pattern of decline, changing the street from a run-down neighborhood service center into one of Portland's main shopping attractions. Hawthorne today could hardly be more different from how it was in 1981 when it was described thus:

Many of the district's characteristic older two-story commercial buildings are poorly maintained. Most merchants report declining receipts. Many retail shops have closed and been replaced by nonretail uses. Some storefronts are even boarded up. Litter accumulates, and growing crime frightens merchants and area residents. Heavy traffic congestion on Hawthorne creates an oppressive environment for pedestrians (PBP 1981, p. 3).

During the intervening years, under the aegis of an active business association, the Hawthorne merchants have improved the appearance of the boulevard, attracting specialized stores and a wealthier clientele. Specialization, which began with music, book and antique stores, has expanded with the appearance of appealing restaurants and gift shops. By tracing and classifying businesses on Hawthorne I was able to distinguish three parallel trends which characterize Hawthorne's commercial transition. Since 1980 the district's orientation has shifted from services to retailing, from the immediate neighborhoods to the whole metropolitan area, and from conventional to 
specialized goods. The number of businesses grew by nearly $20 \%$ during the study period; a drop in the number of convenience and non-retail activities being offset by dramatic increases in restaurants, apparel, and gift shops.

Coincident with this progression towards high-order consumer goods was a change in Hawthorne's clientele. A dichotomous cultural transition took place in which both conspicuous consumers and active anti-consumers made their presence felt on the boulevard. The latter group now appears to have the upper hand in defining Hawthorne's sense of place, but recent developments hint at a shift towards an atmosphere of more conspicuous consumption and yet more specialized goods. The presence of these 'lifestyle' groups has not excluded local shoppers, and the boulevard still maintains its role as the neighborhood Main Street.

Although Hawthorne serves a much wider market than its immediate neighborhoods, changes in the surrounding areas prompted the commercial transformation and now sustain the revamped Hawthorne. Gentrification seems to have been (unconsciously) undertaken by an intellectual, rather than an economic, elite. The residential areas close to Hawthorne contain many environmentally-aware and socially-conscious people. The area now attracts more of this lifestyle group into the neighborhoods; its reputation is self-perpetuating. Related to this politically correct and bohemian atmosphere is the lesbian presence on the street.

Hawthorne's unique circumstances placed it in an ideal position to take 
advantage of the revitalization movement in the early 1980s. Being cut off from the auto-dominated suburbs helped the street maintain its pedestrian scale and physical integrity; being directly connected to downtown Portland facilitated its rapid revitalization. Already poised for success, the district's advantages over other eastside competitors were further boosted by the 1985 acquisition of funding for a three year Main Street Program. The program, capitalizing on the embryonic revitalization of Hawthorne already underway, assisted business expansion, promotion and organization. Through a concerted effort the Hawthorne Boulevard Business Association stamped a distinct and appealing image of Hawthorne on the consciousness of the Portland public, assuring the district's place as the success story of Inner Southeast. However, this image is in conflict with the more unruly, bohemian image presented by many of the district's stores.

Given the changes that have taken place in the physical and commercial makeup of Hawthorne, it seems clear that the district is undergoing gentrification. Although the term is laced with negative connotations which those involved are loathe to accept, the process affecting Hawthorne is no different from undertakings elsewhere. Local circumstances have created the district's character, distinguishing it from more typical examples of gentrification. Indeed, the Hawthorne renaissance is just one symptom of widespread changes affecting North American society: increased wealth and leisure time are creating a culture in which consumption reigns for those who can afford it. 
The true identity of Hawthorne comes not from its buildings but from its stores and the people they attract. There is a symbiosis between shops and their customers: a potential amrket will attract a store that, in turn, brings in yet more similar people. The increasing presence of various subgroups prompts yet more stores catering to their desires. Godfrey $(1988$, p. 178) notes that the character of the businesses and people found in an area, reflects the search for a subcultural identity. Hawthorne's distinct subcultures underpin its image yet, depending on the observer's perspective, not all of these groups are highly visible. Commercial upgrading on Southest Hawthorne Boulevard has resulted in a cultural change and the consequent redefinition of its sense of place.

Several conclusions can be drawn from this study of Portland's Southeast Hawthorne Boulevard. It is clear that gentrification occurs in commercial districts just as it does in residential areas. Yet commercial revitalization has a more immediate impact on the image of a neighborhood than do residential improvements because business districts are highly visible and attract people from outside the immediate areas. Commercial activites both reflect and create the character of their surrounding neighborhoods.

All gentrified commercial streets are different although they contain many similar elements. Studies need to go beyond general statements about the influx of galleries, boutiques and ethnic restaurants, and begin to analyze the characteristics of stores and their customers to gain a better insight into the lifestyles of gentrifiers. The gentry are neither an economically nor a culturally 
homogenous group; treating them as such limits the potential of cultural analysis.

While almost every city seems to have a model gentrified district, there are also more varied areas which require us to expand the definition of gentrification. Typical areas conform to the stereotyped image of brownstones or Victorian houses renovated to fit the image-conscious lifestyles of wealthy baby-boomers. Cast-iron railings, exposed woodwork, reproduction lamps and pastel paint are typical signs of such residential gentrification. The extent of this phenomenon is now so widespread as to have lost its initial importance as a unique area of study.

More interesting are areas undergoing the same processes but that are not the first to do so in a particular city. These 'secondary' streets, particularly in smaller cities, tend to have less wealthy customers and less expensive stores perhaps because the financial base does not exist to support two high-class districts within the central city. Assuming that the premier shopping street caters to a sub-group of the city's economic and cultural elite, streets which revitalize later represent lower, more diverse social strata.

Hawthorne represents the Portland way of life, or at least the self-image that the city's promoters try to portray, better than does NW 23rd. The latter could be in almost any U.S. city. Portland's stress on pedestrian-friendly environments and recycling is played out on Hawthorne, perhaps started by the coincidence of the Hawthorne Renaissance with late 1980s environmentalism. There are few expensive cars or designer clothes to be seen; retro-hipppie is the image. Hawthorne's focus stems from the low income and well educated 
character of the local population. It differs from 'normal' gentrification in this limited emphasis on conspicuous consumption.

However, the very use of the word 'gentrification' is problematic. Using the term 'gentrification' is like crying 'wolf.' The more it occurs the less seriously it is taken, until it loses all meaning. It seems to have already out-lived its usefulness in academic circles. It is now employed so often and so loosely that it is becoming meaningless. Once defined solely as the influx of young professionals into central city working class areas, it is now applied to everything from the construction of new housing in Vancouver, B.C. (Mills 1988) to the evolution of avant-garde neighbourhoods (Caulfield 1989).

Improvements to residential or commercial areas are described as gentrification without reference to what it really means, yet the process has received such bad press that few of those involved will admit to having anything to do with it. If gentrification is indeed negative, then a new term needs to be coined to refer to positive revitalization. What constitutes good and bad upgrading clearly depends on the observer's perspective. Most Hawthorne merchants see recent improvements in a positive light. However, owners of the upscale businesses largely deny that gentrification is occurring, while those on the PC side talk about it freely.

A further problem is that gentrification now appears to be ubiquitous in that all pedestrian streets which are not declining are changing is this particular direction. As postmodern culture becomes both accessible and acceptable to 
more people so more stores and restaurants will become 'gentrified.' What is often heralded as gentrification may merely be a transformation of stores in keeping with current societal trends. Society as a whole, starting with the upper echelons and trickling down, is undergoing a transformation. Gentrification, in the sense of an emphasis on aesthetics and conspicuous consumption, seems inevitable.

In spite of any misgivings about the usefulness of the term, the crux of this study involved describing Hawthorne in the context of gentrification. Hawthorne has all the elements of a gentrified street. Counts of business types show it to be just like other upgrading shopping streets. The boulevard has seen an influx of retail businesses catering to a wealthier clientele than frequented the street fifteen years ago. It has more than its fair share of galleries, boutiques and specialty stores, has undertaken both physical and economic improvements.

Relying simply on numerical measures underplays the differences between individual districts. The exact type of stores has a large impact on an area's atmosphere: not all art galleries are the same, just as not all Chinese restaurants are the same. It is the precise mix of stores, combined with the built environment, that creates the unique atmosphere that is 'Hawthorne.'

It is perhaps part of a second wave of gentrification, a new form of central city revitalization with its philosophy based on increased environmental awareness rather than on the conspicuous consumption of the previous decade; an example of effective gentrification by a group other than yuppies. Ley (1980, p. 257) notes 
that "[a]n urban strategy favoring a high level of consumption with style will only serve to attract the wealthy and penalize social groups with limited market power." Hawthorne's apparent rejection of consumption has prevented it, thus far, from becoming a ghetto of the rich.

This promotion of environmental awareness, anti-Bush politics and cultural diversity, gives Hawthorne a distinct image to which the street can attribute its success. Portland likes to see itself as a green city - in all senses of the word and, as such, Hawthorne Boulevard epitomizes the city's self-image: it is more 'Portland' than the more conventionally gentrified NW 23rd.

Tracing commercial and cultural progression from past to present cannot be complete until the question of what will happen to Southeast Hawthorne Boulevard in the future is addressed. Judging from recent developments, the revitalization shows no signs of slowing down and it is realistic to predict that the trend will continue. While it easy to foresee the continuation of upgrading, the direction further improvements may take is less predictable. There seem to be two possible courses the street could follow in the future. It could continue to develop a peculiar politically correct form of gentrification, maintaining the current balance between consumption and anti-consumption, and between regional and neighborhood businesses. Alternatively, it could progress towards irrefutable gentrification in which conspicuous consumption would dominate.

Hawthorne is not obviously progressing from 'bohemian influx' to 'middleclass transition' (as identified by Godfrey (1988) in San Fransisco) but, rather, the 
two groups appear to have reached an equilibrium where neither is gaining ground at the expense of the other. Indeed, recent trends suggest that the street will maintain its yuppie/PC equilibrium; for every expensive specialty store that opens there is a new venture selling second-hand goods. The shift towards regional businesses noted in 1981 (PBP 1981), continues to expand the district's market area, yet the regional businesses also serve the local population. It is this dual role - the intermingling of local and regional businesses - which generates Hawthorne's vitality.

Hawthorne is, in the eyes of its newer merchants, in an almost ideal situation. There are a few remaining buildings which could be renovated and the blank wall of the Fred Meyer building is a constant source of chagrin but, overall, the boulevard is a success. Yet Hawthorne is now caught in a dilemma: business owners want the revitalization to continue but not so far that it progresses to a higher level of gentrification, or so that it alienates local families who patronize the boulevard.

I have argued that gentrification is already underway. It is not often perceived as such because the term has negative overtones and because most businesses are still inexpensive when compared to those on NW 23rd. Almost all conversations about Hawthorne entail some comparison with NW 23rd and how Hawthorne is nowhere near the extremes that its sister street has reached. Although Hawthorne is less gentrified than some streets in Portland and elsewhere, it is more gentrified than most commercial street. Hawthorne retains a 
blend of diverse subgroups unlike those found in most shopping districts.

The debate here is not one of process but, rather, one of structure and form. The process of gentrification is occurring on Hawthorne. Whether it has gone far enough to truly warrant the description of being gentrified is less clear. While the process is distinct, what constitutes a state of gentrification remains ambiguous. It takes more than a couple of coffee shops and new awnings to constitute gentrification. I have interpreted the term 'gentrification' within the context of Hawthome experience, and the term refers to all improvements undertaken after the district was completely renovated and all vacancies filled. However, gentrification varies from place to place and the tipping point at which revitalization becomes gentrification depends on individual circumstances.

On understudied commercial streets, gentrification appears to take forms that are not as readily identified as are cases of residential gentrification. The grouping of stores and restaurants appears corresponding to the clustering of subcultural groups is a fairly recent phenomenon. Only recently have emerging urban social groups been able to create places specifically attuned to their lifestyle. Hawthorne continues to upgrade and adapt, reflecting both its neighborhood and the city as a whole. The district is now in transition. The current situation indicates that Hawthorne will continue to attract specialized businesses and, gradually, become less accessible to its long-time patrons. 


\section{REFERENCES}

Adler, Sy and Johanna Brenner. 1992. Gender and space: lesbians and gay men in the city. International Journal of Urban and Regional Research 16, 1: 2434.

Bell, Daniel. 1973. The Coming of Post-industrial Society. New York: Basic Books.

Bogle, Lee A. (ed.) 1986. A Synopsis of the Resource Team Report For The Hawthome Boulevard Business Association. Portland: Oregon Downtown Development Association.

Bondi, Liz. 1990. Gender divisions and gentrification: a critique. Institute of British Geographers, Transactions N.S. 16: 190-198.

- 1992. Gender symbols and urban landscapes. Progress in Human Geography 16, 2: 157-170.

Bourne, Larry. 1991. Recycling urban systems. Economic Geography 67,3: 185209.

Castells, Manuel. 1983. The City and the Grass Roots. Berkeley: University of California Press.

Castells, Manuel and Karen Murphy. 1982. Cultural identity and urban structure: The spatial organization of San Francisco's gay community. Urban Affairs Review 22: 237-259.

Caulfield, Jon. 1989. Gentrification and desire. Canadian Review of Sociology and Anthropology 26: 617-32.

Clark, David. 1985. Post-industrial America. London: Metheun.

Cole Directory of Portland. 1980-92. Portland: Cole Publications and Information Services.

Crawford, Margaret. 1992. The World in a Shopping Mall, pp. 3-30, in Michael Sorkin (ed.) Variations on a Theme Park. New York: Noonday Press. 
Cybriwsky, Roman. 1978. Social aspects of neighborhood change. Association of American Geographers, Annals 68, 1: 17-33.

Dear, Michael. 1988. The postmodern challenge: reconstructing human geography. Institute of British Geographers, Transactions N.S. 13: 262-74.

DeGraff, Rob. 1986. Quarterly Report for HBBA's Urban Center's Program (July through September 1986). Portland: Portland Development Commission.

- 1987a. Quarterly Report for HBBA's Urban Center's Program, January 9, 1987 (October through December 1986). Portland: Portland Development Commission.

- 1987b. Quarterly Report for HBBA's Urban Center's Program, April 21987 (January through March 1987). Portland: Portland Development Commission.

- Undated (circa July 1988). Hawthome Urban Center Program Report to Portland Development Commission. Portland: Portland Development Commission.

Feminist Broadcast Quarterly. September 1992. Portland: FBQ.

Glisson, Linda S. 1984. Main Street: Open For Business. Washington, D.C.: National Main Street Center, National Trust for Historic Preservation.

Godfrey, Brian J. 1988. Neighborhoods in Transition: The Making of San Francisco's Nonconformist Communities. Berkeley: University of California Press.

Hall, Peter. 1975. The Urban Culture and the Suburban Culture, pp. 162-177, in Michael e. Eliot Hurst (ed.) I Came to the City. Boston: Houghton-Mifflin Co.

Hamnett, Chris. 1984. Gentrification and residential location theory: a review and assessment, pp. 283-319, in D. Herbert and $R$. Johnston (eds.) Geography and the Urban Environment. Chicester: Wiley.

- 1991. The blind men and the elephant: the explanation of gentrification. Institute of British Geographers, Transactions N.S. 16: 173-189.

Harrison, Michael. 1980. Map Development. Support Document \#12, Recommended Comprehensive Plan. Portland: Portland Bureau of Planning. 
Hawthorne Boulevard Business Association (HBBA). The Gazette. 1985-1992. . 1985. Main Street: A Solution Based on Experience.

. 1991. Happenin' Hawthorne, Historic Hawthorne.

. 1992. Hawthome District Business Directory 1992/1993.

Henig, Jeffrey R. 1982. Gentrification in Adams Morgan. Washington, D.C.: George Washington University.

Hodge, David C. 1980. Revitalization as a challenge to diversity?: Seattle, pp. 187-203, in Shirley Bradway Laska and Daphne Spain, Back to the City: Issues in Neighborhood Renovation. New York: Pergamon Press.

Holdsworth, Deryck. (ed.). 1985. Reviving Main Street. Toronto: University of Toronto Press.

Irving, Stephanie. (ed.). 1990. Portland Best Places. Seattle: Sasquatch Books. Jackson, Peter. 1989. Maps of Meaning. London: Unwin Hyman.

Johnston, R.J. 1991. A place for everything and everything in its place. Institute of British Geographers, Transactions N.S. 16: 131-147.

Jones, Ken and Jim Simmons. 1987. Location, Location, Location: analyzing the retail environment. Toronto: Methuen.

Knox, Paul. 1982. Urban Social Geography. New York: Longman Inc.

Lauria, M. and L. Knopp. 1985. Toward an analysis of the role of gay communities in the urban renaissance. Urban Geography 6: 152-69.

Levine, Martin P. 1979. Gay Ghetto, pp. 182-204, in Martin P. Levine (ed.) Gay Men: The Sociology of Male Homosexuality. New York: Harper \& Row.

Lew, Alan. 1983. Thematic Revitalization of Older Retail districts in the Pacific Northwest. Master's thesis, University of Oregon.

Ley, David. 1980. Liberal ideology and the postindustrial city. Association of American Geographers, Annals 70, 2: 238-58.

1983. A Social Geography of the City. New York: Harper \& Row. 
- 1988. Interpretive social research in the inner city, pp. 121-138, in John Eyles (ed.) Research in Human Geography: Introductions and Investigations. New York: Basil Blackwell.

Lynch, Kevin. 1960. The Image of The City. Cambridge: The MIT Press.

Markusen, Ann. 1981. City spatial structure, women's household work, and national urban policy, pp. 20-41, in Catharine R. Stimpson, Elsa Dixler, Martha J. Nelson, and Kathryn B. Yatrakis. Women and the American City. Chicago: The University of Chicago Press.

Meinig, D. W. 1979. Introduction, pp. 1-7, and Symbolic Landscapes, pp. 164194, in D. W. Meinig (ed.) The Interpretation of Ordinary Landscapes. New York: Oxford University Press.

Mills, C. A. 1988. "Life on the upslope": the postmodern landscape of gentrification. Environment and Planning D 6: 169-189.

Oregon Downtown Development Association (ODDA). 1987. Hawthorne Boulevard Landscape and Design Plan. Portland: ODDA.

- 1990. Main Street Progress. Portland: ODDA.

Palm, Risa. 1973. Factorial ecology and the community of outlook. Association of American Geographers, Annals. 63, 3: 341-346.

Portland Bureau of Planning (PBP). 1981. Hawthorne Business District: Commercial District/Air Quality Project. Portland: Bureau of Planning.

Relph, Edward. 1987. The Modern Urban Landscape. Baltimore: The Johns Hopkins University Press.

- 1989. Responsive methods, geographical imagination and the study of landscape, pp. 149-163, in Audrey Kobayashi and Suzanne Mackenzie Remaking Human Geography. Boston: Unwin Hyman.

Riley, Robert B. 1980. Speculations on the new American landscapes. Landscape 24, 3: 1-9.

Rose, D. 1984. Rethinking gentrification: beyond the uneven development of Marxist urban theory. Environment and Planning D: Society and Space 1: 47-74. 
Schaffer, Richard and Smith, Neil. 1986. The gentrification of Harlem? Association of American Geographers, Annals 76: 347-365.

Short, R.J. 1989. Yuppies, yuffies and the new urban order. Institute of British Geographers, Transactions N.S. 14: 173-88.

Smith, Neil. 1979. Toward a theory of gentrification: a back to the city movement of capital not people. Joumal of the American Planning Association 45: 538-48.

- 1987. Of Yuppies and housing: gentrification, social restructuring, and the urban dream. Environment and Planning D: Society and Space 5: 151-172.

Smith, Neil and Peter Williams (eds.) 1986. Gentrification of the City. Boston: Allen and Unwin.

Solomon, R. J. 1966. Procedures in Townscape Analysis. Association of American Geographers, Annals 56: 254-68.

Southeast Examiner. 1991-1992 (various issues). Portland.

Stewart, John. 1985. Breathing life back into downtown, pp. 63-92, in Deryck Holdsworth (ed.) Reviving Main Street.

Sunset Magazine. October 1992. Portland's East Side Story.

The Oregonian. 26 April 1992, pp. H1, H4. Richmond Renaissance.

Weiss, Michael J. 1988. The Clustering of America. New York: Harper \& Row.

Whitehand, J. W. R. 1987. The Changing Face of Cities. Oxford: Basil Blackwell.

Willamette Week Restaurant Guide. October 1992.

Winters, Christopher P. 1979. The social identity of evolving neighborhoods. Landscape 23, 1: 8-14.

Zukin, Sharon. 1991. Landscapes of Power: from Detroit to Disney World. Berkeley: University of California Press. 
APPENDIX A

ANNUAL BUSINESS TURNOVER BY ADDRESS

(Source: Cole Directories 1980-1992) 
All business in the study area between 1980 and 1992 are included in this appendix. Changes since the publication of the 1992 Cole Directory are listed under '10/92,' and accurate as of October 1st, 1992.

Addresses on side streets are prefixed by the street number. Odd numbers are on the north side of the street (and the west side of north-south streets), even numbers are on the south side of the street (and the east side of north-south streets).

Listings for the whole of Hawthorne Boulevard are available, in spreadsheet format, from the geography department at Portland State University. 


$\begin{array}{ll} & 2800 \\ 1980 & \text { Safeway } \\ 1981 & \text { Safeway } \\ 1982 & \text { Safeway } \\ 1983 & \text { Safeway } \\ 1984 & \text { Safeway } \\ 1985 & \text { Safeway } \\ 1986 & \text { Safeway } \\ 1987 & \text { Safeway } \\ 1988 & \text { Safeway } \\ 1989 & \text { Safeway } \\ 1990 & \text { Safeway } \\ 1991 & \text { Safeway } \\ 1992 & \text { Safeway } \\ 10 / 92 & \text { Safeway }\end{array}$

2828

2928

1980

1981

1982

1983

1984

1985

1986

1987

1988

1989

1990

1991

1992

$10 / 92$
2804

State Liquor Control

State Liquor Control

State Liquor Control

State Liquor Control

State Liquor Control

State Liquor Control

State Liquor Control

State Liquor Control

State Liquor Control

State Liquor Control

Hawthorne Liquor Store

Hawthorne Liquor Store

Hawthorne Liquor Store

Hawthorne Liquor Store
2805

Hare Krishna Temple

Hare Krishna Temple

\begin{tabular}{c}
- \\
$\cdots$ \\
$\cdots$ \\
$\cdots$ \\
$\cdots$ \\
$\cdots$ \\
\hdashline \\
\hline- \\
- \\
- \\
-
\end{tabular}
2942

Springtime Thrifty Cleaners Springtime Thrifty Cleaners Springtime Thrifty Cleaners Springtime Thrifty Cleaners Springtime Thrifty Cleaners Springtime Thrifty Cleaners Springtime Thrifty Cleaners Springtime Thrifty Cleaners Springtime Thrifty Cleaners Springtime Thrifty Cleaners Springtime Thrifty Cleaners Springtime Thrifty Cleaners Springtime Thrifty Cleaners Springtime Thrifty Cleaners

$\begin{array}{lll} & 2950 & 3001 \\ 1980 & \text { Plaid Pantry } & \text { Tastee Freez Icecream } \\ 1981 & \text { Plaid Pantry } & \text { Tastee Freez Icecream } \\ 1982 & \text { Plaid Pantry } & \text { Tastee Freez Icecream } \\ 1983 & --- & \text { Tastee Freez Icecream } \\ 1984 & \text {-. Express Grocery } & \text { Tastee Freez Icecream } \\ 1985 & \text { Lee's Expre- } \\ 1986 & \text { Lee's Express Grocery } & \text { Taco Loco } \\ 1987 & \text { Lee's Express Grocery } & \text { Mister Burger } \\ 1988 & \text { Lee's Express Grocery } & \text { Y's Burger } \\ 1989 & \text { Lee's Express Grocery } & \text { Y's Burger } \\ 1990 & \text { Lee's Express Grocery } & \text { House of Malaka } \\ 1991 & \text { Lee's Express Grocery } & \text { House of Malaka } \\ 1992 & \text { Lee's Express Grocery } & \text { RJ's All-American Restaurant } \\ 10992 & \text { Lee's Express Grocery } & \text { At The Hop }\end{array}$

\section{6}

Claudia's Tavern

Claudia's Tavern

Claudia's Tavern

Claudia's Tavern

Claudia's Tavern

Claudia's Tavern

Claudia's Tavern

Claudia's Tavern

Claudia's Tavern

Claudia's Tavern

Claudia's Tavern

Claudia's Tavern

Claudia's Tavern

Claudia's Tavern 


\begin{tabular}{ll} 
& 3020 \\
1980 & Remmington Keller \\
1981 & Remmington Keller \\
1982 & Remmington Keller/ \\
& NW Surf Equipment \\
1983 & Remmington Keller \\
1984 & Native American Rehab \\
1985 & Native American Rehab \\
1986 & Native American Rehab \\
1987 & Native American Rehab \\
1988 & Native American Rehab \\
1989 & Native American Rehab \\
1990 & Karate for Women \\
1991 & Spirit and Spin Inc/ \\
& Vinyl Industries \\
1992 & Spirit and Spin Inc/ \\
& Vinyl Industries \\
$10 / 92$ & Spirit and Spin Inc \\
& Vinyl Industries \\
& \\
\hline & 3031 \\
1980 & Playland Day Nursery \\
1981 & Playland Day Nursery \\
1982 & Playland Day Nursery \\
1983 & Playland Day Nursery \\
1984 & Playland Day Nursery \\
1985 & American Youth Hostel \\
1986 & American Youth Hostel \\
1987 & American Youth Hostel \\
1988 & American Youth Hostel \\
1989 & American Youth Hostel \\
1990 & American Youth Hostel \\
1991 & American Youth Hostel \\
1992 & American Youth Hostel \\
$10 / 92$ & American Youth Hostel \\
\hline
\end{tabular}

311521

$\begin{array}{ll}1980 & \ldots \\ 1981 & \ldots \\ 1982 & \ldots \\ 1983 & \ldots \\ 1984 & \ldots \\ 1985 & \ldots \\ 1986 & \ldots \\ 1987 & \ldots \\ 1988 & \ldots \\ 1989 & \ldots \\ 1990 & \ldots \\ 1991 & \ldots \\ 1992 & \text { Karate for Women } \\ 10992 & \text { Karate for Women }\end{array}$

-.-

$\cdots$

$\cdots$

Wistings TV

Wistings TV

Wistings TV

-.-

Angie's Cafe

Angies Cafe/

As You Like It

As You Like It/

Creative Treasures

3032

Wisting's TV

Wisting's TV

Wisting's TV

Wisting's TV

Mr Michael's Deli

Mr Michael's Deli

Mr Michael's Deli

Mr Michael's Deli

Mr Michael's Deli

Mr Michael's Deli

Mr Michael's Deli

Mr Michael's Deli

Mr Michael's Deli

3106

Nelson Properties

Nelson Properties

Nelson Properties

Nelson Properties

Nelson Properties

Nelson Properties

Nelson Properties

Nelson Properties

Nelson Properties

Nelson Properties

Nelson Properties

Nelson Properties

Nelson Properties

Nelson Properties
3028

Underwriters Inc

Underwriters Inc

Underwriters Inc

Underwriters Inc

Supermicro computer

-..

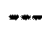

$\cdots$

One and Two Dollar Video

Mr D's Video

Mr D's Video/

McKeon and Dempsey

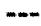

314111

$\cdots$

Hawthorne Technology Hawthorne Technology Hawthorne Technology Hawthorne Technology

--.

3129

Foster Businsess Systems -..-

Native American Rehab

Native American Rehab

$\cdots$

Hawthorne Boulevard Books Hawthorne Boulevard Books Hawthorne Boulevard Books Hawthorne Boulevard Books Hawthorne Boulevard Books Hawthorne Boulevard Books Hawthorne Boulevard Books Hawthorne Boulevard Books 
3130

1980

AAA Service Inc

1981 AAA Service Inc

1982 AAA Service Inc

1983 AAA Service Inc

1984 AAA Service Inc

1985 AAA Service Inc

1986 AAA Service Inc

1987 AAA Service Inc

1988 AAA Service Inc

1989 AAA Service Inc

1990 AAA Service Inc

1991 Clark's AAA Repair

1992 Clark's AAA Repair

10/92 Clark's AAA Repair
3130

Harris Uniforms

Harris Uniforms

Harris Uniforms

Harris Uniforms

Harris Uniforms

Harris Uniforms

Harris Uniforms

-.-

Neon Art and Tube Bending

Neon Art and Tube Bending

Neon Art and Tube Bending

Neon Art School

Neon Art School

Neon Art School
3140

Stereo World

Epic Speaker Co Inc Attorney Messenger Co

Conifer Group

Conifer Group

Conifer Group

Conifer Group

Conifer Group

Conifer Group

Conifer Group

Conifer Group

Conifer Group

Conifer Group

Conifer Group

\section{5}

1980

1981

1982

1983

1984

1985

1986

1987

1988

1989

1990

1991

1992

$10 / 92$
Doggie Delight

Doggie Delight

Doggie Delight

Doggie Delight

Doggie Delight

Doggie Delight

Doggie Delight

Doggie Delight

Lanai Cafe

Lanai Cafe

Lanai Cafe

Lanai Restaurant

Lanai Restaurant

Lanai Restaurant
3200

$\cdots$

-..

$\cdots$

$\cdots$

$\cdots$

$\cdots$

$\cdots$

$\ldots$

$\cdots$

Devine's Sew Happy

Devine's Sew Happy

Devine's Sew Happy
3202

American Theatre Supply

American Theatre Supply

American Theatre Supply

American Theatre Supply

-..

$-\cdot$

$-\cdot$

$-\cdots$

Wildflowers on Hawthorne

Wildflowers on Hawthorne

Wildflowers on Hawthorne

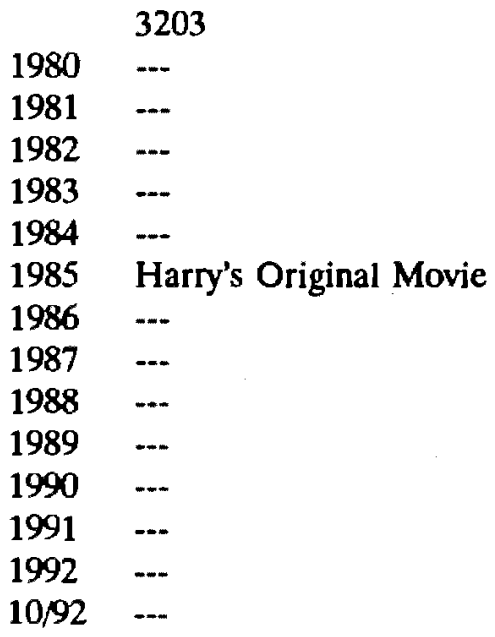

3204

3206

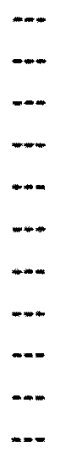

Savy Plus

Savy Plus

Savy Plus

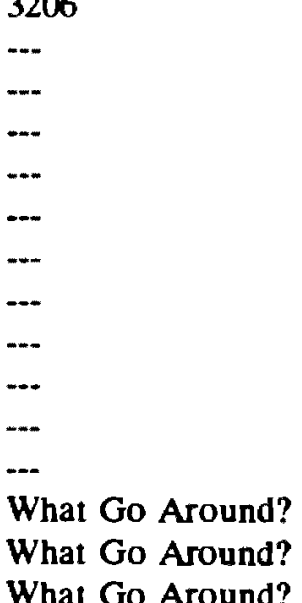


3207

1980

1981

1982

1983

1984

1985

1986

1987

1988

1989

1990

1991

1992

$10 / 92$

$$
3239
$$

1980

1981

1982

1983

1984

1985

1986

1987

1988

1989

1990

1991

1992

Coit/Reese Cleaners

Coit/Reese Cleaners

Coit/Reese Cleaners

Coit/Reese Cleaners

Coit/Reese Cleaners

Coit/Reese Cleaners

Coit/Reese Cleaners

Coit/Reese Cleaners

Coit/Reese Cleaners

Coit/Reese Cleaners

Coit/Reese Cleaners

Coit/Reese Cleaners

Coit/Reese Cleaners

10/92 Coit/Reese Cleaners

3257

1980 Life Environments plants

1981 Life Environments plants

1982 Life Environments plants

1983 Life Environments plants

1984 The Golden Swan

1985 The Golden Swan

1986 The Golden Swan

$1987 \quad \ldots$

$1988 \quad-$.

$1989 \quad \ldots$

$1990 \quad \ldots$

$1991 \ldots$

$1992 \quad \ldots$

$10 / 92$
3210

Elite Productions

...

$\cdots$

$--$

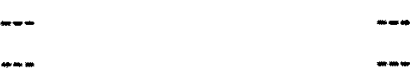

$\cdots$

$\cdots$

$\cdots$

In Her Image Gallery

In Her Image Gallery

In Her Image Gallery

3240

3257

-..

$\cdots$

$\cdots$

$\cdots$

$\ldots$

Wally's Ribs

-.-

-.-

Best Rentals

Crone Magic/

Hair Forte

Crone Magic/

Hair Forte

Crone Magic/

Hair Forte

3257

3267

Gearhart \& Gearhart

Gearhart \& Gearhart

Gearhart \& Gearhart

Gearhart \& Gearhart

Gearhart \& Gearhart

Gearhart \& Gearhart

Gearhart \& Gearhart

Gearhart \& Gearhart

Gearhart \& Gearhart

Gearhart \& Gearhart

Gearhart \& Gearhart

Gearhart \& Gearhart

Gearhart \& Gearhart

Gearhart \& Gearhart 


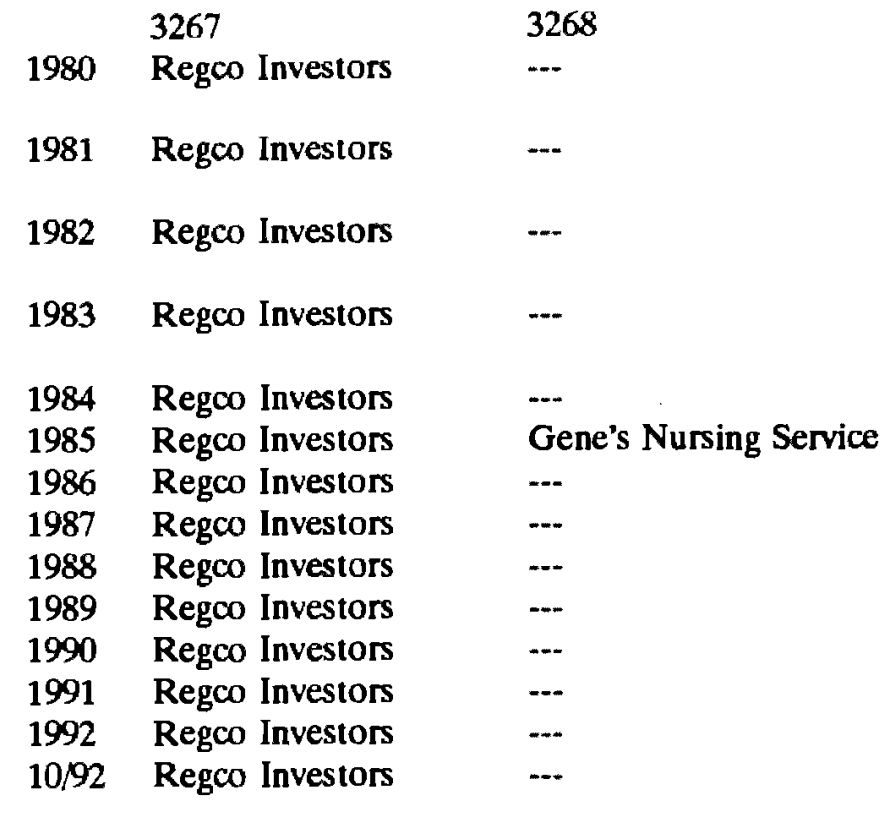

3290

\begin{tabular}{ll}
1980 & Attorney Messenger \\
1981 & Attorney Messenger \\
1982 & $\ldots$ \\
1983 & $\ldots$ \\
1984 & $\ldots$ \\
1985 & $\ldots$ \\
1986 & $\ldots$ \\
1987 & $\ldots$ \\
1988 & $\ldots$ \\
1989 & $\ldots$ \\
1990 & $\ldots$ \\
1991 & $\ldots-$ \\
1992 & $\ldots$ \\
$10 / .-$ \\
\hline
\end{tabular}

3327

1980
Hellums Mechanical Hellums Mechanical Hellums Mechanical Hellums Mechanical Hellums Mechanical Hellums Mechanical Hellums Mechanical Hellums Mechanical Hellums Mechanical Hellums Mechanical Hellums Mechanical Hellums Mechanical Hellums Mechanical Hellums Mechanical
331525

Devone Divine Devone Divine Devone Divine Devone Divine Devone Divine

-..

\section{$-\cdots$}

\section{8}

Tamak Inc Tamak Inc Tamak Inc Tamak Inc Tamak Inc Tamak Inc Tamak Inc Tamak Inc Tamak Inc Tamak Inc Tamak Inc Tamak Inc Tamak Inc Tamak Inc
3279

Santana Hair Design/

The Woodcarver

Santana Hair Design/

The Woodcarver

Santana Hair Design/

The Woodcarver

Santana Hair Design/

The Woodcarver

Graystone Gallery

Graystone Gallery

Graystone Gallery

Graystone Gallery

Graystone Gallery

Graystone Gallery

Graystone Gallery

Graystone Gallery

Graystone Gallery

Graystone Gallery

3315

Rose City Paper Box Inc Rose City Paper Box Inc Rose City Paper Box Inc Rose City Paper Box Inc Rose City Paper Box Inc Rose City Paper Box Inc Rose City Paper Box Inc Rose City Paper Box Inc Rose City Paper Box Inc Rose City Paper Box Inc Rose City Paper Box Inc CY's Shades and Collectibles Robert Welsh Rip City/Top Dog

3328

W Faulkner Collection

W Faulkner Collection

W Faulkner Collection

W Faulkner Collection

W Faulkner Collection

W Faulkner Collection

W Faulkner Collection

W Faulkner Collection

W Faulkner Collection

W Faulkner Collection

W Faulkner Collection 
3328

$\begin{array}{ll}1980 & -- \\ 1981 & -- \\ 1982 & -- \\ 1983 & -- \\ 1984 & -- \\ 1985 & -- \\ 1986 & \text { The Perfume House } \\ 1987 & \text { The Perfume House } \\ 1988 & \text { The Perfume House } \\ 1989 & \text { The Perfume House } \\ 1990 & \text { The Perfume House } \\ 1991 & \text { The Perfume House } \\ 1992 & \text { The Perfume House } \\ 10 / 92 & \text { The Perfume House }\end{array}$

3335

1980 Justice Co

1981 Justice Co

1982 Justice Co

1983 Justice Co

1984 Justice Co

1985 Justice Co

1986 Justice Co

1987 Justice Co

1988 Justice Co

1989 Justice Co

1990 Justice Co

1991 Justice Co

1992 Justice Co

10/92 Justice Co

3343

1980 Ancina Clinic

1981 Ancina Clinic

1982 Ancina Clinic

1983 Ancina Clinic

1984 Ancina Clinic

1985 Ancina Clinic

1986 Ancina Clinic

1987 Ancina Clinic

1988 Ancina Clinic

1989 Ancina Clinic

1990 Ancina Clinic

1991 Ancina Clinic

1992 Ancina Clinic

10/92 Ancina Clinic
3335

Farmers Insurance

Farmers Insurance

Farmers Insurance

Farmers Insurance

Farmers Insurance

Farmers Insurance

Farmers Insurance

Farmers Insurance

Four Star Productions

Just Us Travel

Just Us Travel

Just Us Travel

Just Us Travel

3340

Hawthorne Beauty Salon

Hawthorne Beauty Salon

Hairbourne

You're Looking Good/

River City Seafood

You're Looking Good

You're Looking Good

You're Looking Good

You're Looking Good/

Guitar Crazy

You're Looking Good/

Guitar Crazy

Guitar Crazy

-..

Vitna Print

Vitna Print

3344

-.-

$\cdots$

Rollin Records

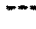

$\cdots$

...

$\cdots$

$\cdots$

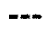

$\cdots$

$\cdots$

Think Good Thoughts

Think Good Thoughts
3335

Roxanne Russell

Roxanne Russell

Margie Holmes

Margie Holmes

Margie Holmes

Margie Holmes

Margie Holmes

Margie Holmes

Margie Holmes

Margie Holmes

Margie Holmes

Margie Holmes

Margie Holmes

Margie Holmes

3341

Public Finance Corp

Public Finance Corp

-..

$\cdots$

-..

Eastside Photo

Eckankar Cascade

Eckankar Cascade

Eckankar Cascade

Eckankar Cascade

Eckankar Cascade

Eckankar Cascade

Eckankar Cascade

Bead Needs

3354

Epicurean Delight

-..

Couchinis Restaurant

Hawthorne Street Cafe

Hawthorne Street Cafe

Hawthorne Street Cafe

Hawthorne Street Cafe

Hawthorne Street Cafe

Hawthorne Street Cafe

Hawthorne Street Cafe

Hawthorne Street Cafe

Hawthorne Street Cafe

Hawthorne Street Cafe

Hawthorne Street Cafe 
341432

1980 JB Frederick Ltd

1981 JB Frederick Ltd

1982

1983

1984

1985

1986

1987

1988

1989

1990

1991

1992

$10 / 92$
341527

Chapel of Light Church

Chapel of Light Church

Chapel of Light Church

West Coast Power

West Coast Power

Sprr Stg \& Lighting Inc

Sprr Stg \& Lighting Inc

Sprr Stg \& Lighting Inc

3401

1980

1981

1982

1983

1984

1985

1986

1987

1988

1989

1990

1991

1992

$10 / 92$
Showcase Music

Showcase Music

Showcase Music

Showcase Music

Showcase Music

Showcase Music

Showcase Music

Showcase Music

Showcase Music

Showcase Music

Showcase Music

Showcase Music

Showcase Music

Showcase Music
3415

1980 Nearly New Shop

1981 Nearly New Shop

1982 ...

1983

1984

1985

1986

1987

1988

1989

1990

1991

1992

$10 / 92$
Desitrek Recording

Desitrek Recording

Desitrek Recording

Desitrek Recording

Desitrek Recording

Desitrek Recording

Desitrek Recording

Desitrek Recording

Desitrek Recording

Desitrek Recording

Desitrek Recording
3401

-..

-..

Precision Guitar Repair

Oregon Bass Company

Oregon Bass Company

GTS Electronics

GTS Electronics

GTS Electronics

GTS Electronics

GTS Electronics

GTS Electronics

3420

Arctic Circle

Arctic Circle

Arctic Circle

Arctic Circle

Arctic Circle

Arctic Circle

Arctic Circle

Arctic Circle

Arctic Circle

Arctic Circle

Arctic Circle

Arctic Circle

Arctic Circle

Arctic Circle
341544

Christian Yellow Pages

Arrow Typesetting

Arrow Typesetting

Arrow Typesetting

Arrow Typesetting

Arrow Typesetting

Arrow Typesetting

Arrow Typesetting

Arrow Typesetting

Arrow Typesetting

Arrow Typesetting

Arrow Typesetting

Arrow Typesetting

Arrow Typesetting

3409

Sunrise Sheet Music

Sunrise Sheet Music

Sunrise Sheet Music

$\cdots$

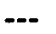

-..

$\cdots$

$\cdots$

$\cdots$

$\cdots$

$\ldots$

$\cdots$

Nibbles on Hawthorne Nibbles on Hawthorne Nibbles on Hawthorne Nibbles on Hawthorne 


$\begin{array}{ll}1980 & -- \\ 1981 & -- \\ 1982 & -- \\ 1983 & -- \\ 1984 & -- \\ 1985 & \ldots- \\ 1986 & -- \\ 1987 & -- \\ 1988 & -- \\ 1989 & \ldots \\ 1990 & \text { Priscilla Ann } \\ 1991 & \text { Priscilla Ann } \\ 1992 & \text { Priscilla Ann } \\ 10 / 92 & \text { Priscilla Ann }\end{array}$

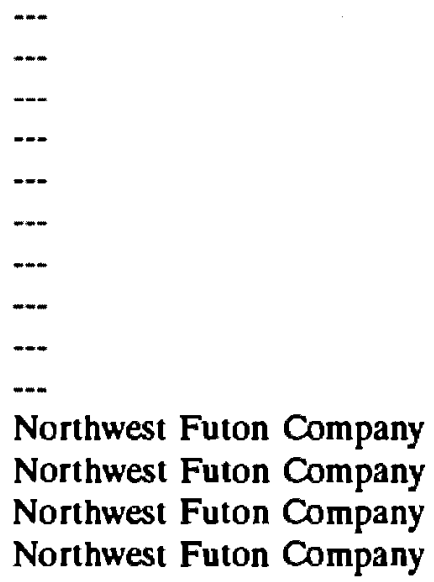

351416

Heine Real Estate

Heine Real Estate

Heine Real Estate

Heine Real Estate

Heine Real Estate

Heine Real Estate

Heine Real Estate

Heine Real Estate

Heine Real Estate

Heine Real Estate

Heine Real Estate

-..

$-\cdot$
351430

Michael Emert

Michael Emert

Michael Emert

Michael Emert

Michael Emert

Michael Emert

Michael Emert

Michael Emert

Michael Emert

Michael Emert

Michael Emert

Michael Emert

Michael Emert

Michael Emert
3500

1980

1981

1982

1983

1984

1985

1986

1987

1988

1989

1990

1991

1992

$10 / 92$
City Glass

City Glass

City Glass

City Glass

City Glass

City Glass

City Glass

City Glass

City Glass

City Glass

City Glass

City Glass

City Glass

City Glass
3508

--.

Ted's Carpet Service

Nearly New Shop

Nearly New Shop

Nearly New Shop

Nearly New Shop

Nearly New Shop

Nearly New Shop

Nearly New Shop

Nearly New Shop

Nearly New Shop

Nearly New Shop

Nearly New Shop
3518

DJ's tavern

DJ's tavern

DJ's tavern

Missouri Tavern

Missouri Tavern

Missouri Tavern

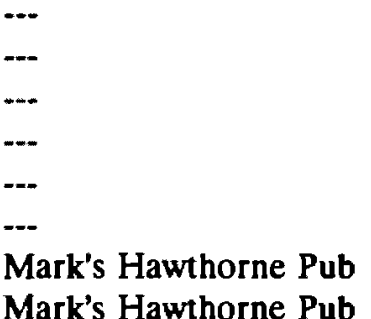




$\begin{array}{ll}1980 & \ldots \\ 1981 & -- \\ 1982 & \ldots \\ 1983 & \ldots \\ 1984 & \ldots \\ 1985 & -. \\ 1986 & \ldots \\ 1987 & \text { Peace } \\ 1988 & \ldots \\ 1989 & \ldots \\ 1990 & -. \\ 1991 & \ldots \\ 1992 & -.- \\ 10 / 92 & \ldots\end{array}$

3526

1980 Nina's Antiques

1981 Nina's Antiques

1982 Nina's Antiques

1983 Nina's Antiques

1984 Nina's Antiques

1985 Nina's Antiques

1986 Nina's Antiques

1987 Timeless Treasures

1988 Timeless Treasures

$1989 \quad$-..

$1990 \quad \ldots$

$1991 \quad \ldots$

$1992 \quad \ldots$

$10 / 92 \quad \ldots$
3522

Holland's Book Store

Holland's Book Store

Holland's Book Store

Holland's Book Store

Holland's Book Store

Who cares

Who cares

Artichoke Music

Artichoke Music

Artichoke Music

Artichoke Music

Artichoke Music

Artichoke Music

Artichoke Music
3525

McGee Blind's and Awnings McGee Blind's and Awnings McGee Blind's and Awnings McGee Blind's and Awnings McGee Blind's and Awnings McGee Blind's and Awnings McGee Blind's and Awnings McGee Blind's and Awnings McGee Blind's and Awnings McGee Blind's and Awnings McGee Blind's and Awnings McGee Blind's and Awnings McGee Blind's and Awnings First Stop Video

3530

The Whole Image

The Whole Image

The Whole Image

The Whole Image

-..

Larry Milam Illustration Larry Milam Illustration Larry Milam Illustration Larry Milam Illustration Larry Milam Illustration

3530

3532

Yestershades

Yestershades

Yestershades

Yestershades

Yestershades

Yestershades

Yestershades

Yestershades

Yestershades

Second Story Books

Second Story Books

Second Story Books

Second Story Books

Second Story Books $\cdots$

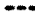


3534

$\begin{array}{ll} & 3534 \\ 1980 & --- \\ 1981 & --- \\ 1982 & --- \\ 1983 & --- \\ 1984 & --- \\ 1985 & --- \\ 1986 & --- \\ 1987 & --- \\ 1988 & --- \\ 1989 & --- \\ 1990 & --- \\ 1991 & \text { Buttertoe's Gifts } \\ 1992 & \text { Buttertoe's Gifts } \\ 1092 & \text { Buttertoe's Gifts }\end{array}$

3538

1980 The Paper Moon

1981 The Paper Moon

1982 The Paper Moon

1983 The Paper Moon

1984 The Paper Moon

1985 The Paper Moon

1986 The Paper Moon

1987 The Paper Moon

1988 The Paper Moon

1989 The Paper Moon

1990 The Cat's Meow

1991 The Cat's Meow

1992 The Cat's Meow

$10 / 92$ The Cat's Meow

3545

1980 Viennese Pastries

1981 German Bakery

1982 German Bakery

1983 German Bakery

1984 German Bakery

1985 German Bakery

1986 Sarah's Cookies

1987 Bowers Bakery

1988 Bowers Bakery

1989 Bowers Bakery

1990 Bowers Bakery

1991 Bowers Bakery

1992 Bowers Bakery

10/92 Bowers Bakery
3535

Scandia Spa

South Seas Tanning Studio

South Seas Tanning Studio

South Seas Tanning Studio

-..

Simon Lake

---

Della's Deco Ware

Grin 'n' Wear It

Grin 'n' Wear It

Grin 'n' Wear It

Grin 'n' Wear It

Grin 'n' Wear It

Madre Tierra

3541

Times and Seasons books

-...

Jean City

Tom's Second Time Around

Somewhere in Time Clothier

Somewhere in Time Clothier

Sew What

Visible Impact Resale Fashion

Visible Impact Resale Fashion

Visible Impact Resale Fashion

Visible Impact Resale Fashion

Visible Impact Resale Fashion

Visible Impact Resale Fashion

Visible Impact Resale Fashion

3549

The Midas Touch

The Midas Touch

Michael's on the Boulevard

-..

Rose City Art Center

Rose City Art Center

Rose City Art Center

Peace

A D Quan Vietnamese

A D Quan Vietnamese

Fu Jin Restaurant

Fu Jin Restaurant

Fu Jin Restaurant
3541

3537

Business controls

Business controls

Business controls

Business controls

Business controls

Business controls

Business controls

Business controls

Business controls

Business controls

Business controls

Business Controls

Tara

Illusionary Designs

Illusionary Designs

Illusionary Designs

Illusionary Designs

Illusionary Designs

3553

Melissa's Kitchen

Melissa's Kitchen

Melissa's Kitchen

Melissa's Kitchen

Macheesmo Mouse

Macheesmo Mouse

Macheesmo Mouse

Macheesmo Mouse

Macheesmo Mouse

Macheesmo Mouse

Macheesmo Mouse

Macheesmo Mouse

Macheesmo Mouse

Macheesmo Mouse 


$\begin{array}{ll}1980 & --- \\ 1981 & -- \\ 1982 & --- \\ 1983 & -- \\ 1984 & \text { Immdt CVR Ctn Dig } \\ 1985 & \text { Immdt CVR Ctn Dig } \\ 1986 & \text { Cotton Delight } \\ 1987 & \text { El Mundo } \\ 1988 & \text { El Mundo } \\ 1989 & \text { El Mundo } \\ 1990 & \text { El Mundo } \\ 1991 & \text { El Mundo } \\ 1992 & \text { El Mundo } \\ 10 / 92 & \text { El Mundo }\end{array}$

3558

1980

1981

1982

1983

1984

1985

1986

1987

1988

1989

1990

1991

1992

$10 / 92$
El Acapulco

El Acapulco

El Acapulco

El Acapulco

Don Juan's Mexican cuisine

Don Juan's Mexican cuisine

Don Juan's Mexican cuisine

Don Juan's Mexican cuisine

-...

Hawthorne Healthcare Center

Hawthorne Healthcare Center

Hawthorne Healthcare Center Hawthorne Healthcare Center

3562

Hladini Enterprises

Ruby's Antiques

Ruby's Antiques

Hawthorne Coffee Merchant

Hawthorne Coffee Merchant

Hawhorne Coffee Merchant

Hawthorne Coffee Merchant

Hawthorne Coffee Merchant

Hawthorne Coffee Merchant

Hawthorne Coffee Merchant

Hawthorne Coffee Merchant

Hawthorne Coffee Merchant

Hawthorne Coffee Merchant
3564

$\cdots$

Fine and Fanciful

Fine and Fanciful

Fine and Fanciful

-..
3574

Adult Center

Adult Center

Adult Center

Adult Center

Adult Center

Sunnyside Up Bakery

Sunnyside Up Bakery

Sunnyside Up Bakery

Sunnyside Up Bakery

Sunnyside Up Bakery

Sunnyside Up Bakery

Sunnyside Up Bakery

Sunnyside Up Bakery

Sunnyside Up Bakery

Sunnyside Up Bakery

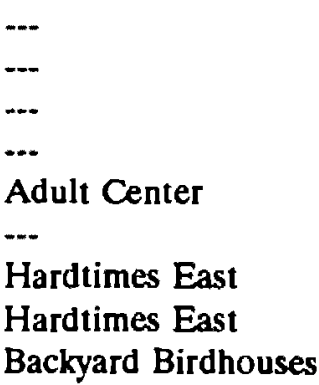


3590

Union Furniture Co

Union Furniture Co

Union Furniture Co

Union Furniture Co

Ruby's Antiques

Ruby's Antiques

Ruby's Antiques

Ruby's Antiques

Ruby's Antiques

Ruby's Antiques

Ruby's Antiques

Ruby's Antiques

Ruby's Antiques

Ruby's Antiques
361428

Hawthorne Stereo

Hawthorne Stereo

Hawthorne Stereo

Hawthorne Stereo

Hawthorne Stereo

Hawthorne Stereo

Hawthorne Stereo

Hawthorne Stereo

Hawthorne Stereo

Hawthorne Stereo

Hawthorne Stereo

Hawthorne Stereo

Hawthorne Stereo

Hawthorne Stereo
3610

$\begin{array}{ll}1980 & -. \\ 1981 & \ldots \\ 1982 & \ldots \\ 1983 & -- \\ 1984 & \text { Bread \& Ink Cafe } \\ 1985 & \text { Bread \& Ink Cafe } \\ 1986 & \text { Bread \& Ink Cafe } \\ 1987 & \text { Bread \& Ink Cafe } \\ 1988 & \text { Bread \& Ink Cafe } \\ 1989 & \text { Bread \& Ink Cafe } \\ 1990 & \text { Bread \& Ink Cafe } \\ 1991 & \text { Bread \& Ink Cafe } \\ 1992 & \text { Bread \& Ink Cafe } \\ 10 / 92 & \text { Bread \& Ink Cafe }\end{array}$

3614

...

$\cdots$

$\cdots$

-.-

$\cdots$

$-.$.

-..

$\cdots$

Linda Loving Florist

Linda Loving Florist

Linda Loving Florist

Linda Loving Florist
3616

East Portland Locksmith East Portland Locksmith East Portland Locksmith East Portland Locksmith East Portland Locksmith East Portland Locksmith East Portland Locksmith East Portland Locksmith East Portland Locksmith East Portland Locksmith East Portland Locksmith East Portland Locksmith East Portland Locksmith

3623

Valley Rental NW Rent Systems. Oregon Paralyzed Vets Oregon Paralyzed Vets Oregon Paralyzed Vets Combs and Scissors Combs and Scissors Combs and Scissors Combs and Scissors Combs and Scissors Cutting Crew Curting Crew Cutting Crew Culting Crew Cutting Crew
(2)

Crocodile Records Crocodile Records Crocodile Records Crocodile Records Crocodile Records Crocodile Records Crocodile Records 
3624

$\begin{array}{ll}1980 & \ldots \\ 1981 & \ldots \\ 1982 & \ldots \\ 1983 & \ldots \\ 1984 & \ldots \\ 1985 & \text { Orpheus Music Compact Discs } \\ 1986 & \text { Orpheus Music Compact Discs } \\ 1987 & \text { Orpheus Music Compact Discs } \\ 1988 & \text { Orpheus Music Compact Discs } \\ 1989 & \text { Orpheus Music Compact Discs } \\ 1990 & \ldots \\ 1991 & \ldots \\ 1992 & \ldots \\ 10 / 92 & \ldots\end{array}$

3628

Lenny's Barber shop

Lenny's Barber shop

Lenny's Barber shop

Lenny's Barber shop

Lenny's Barber shop

Lenny's Barber shop

Lenny's Barber shop

Lenny's Barber shop

Lenny's Barber shop

Lenny's Barber shop

Lenny's Barber shop

Lenny's Barber shop

Lenny's Barber shop

Lenny's Barber shop
3631

Kahl's Carpet Fashions Kahl's Carpet Fashions Kahl's Carpet Fashions Kahl's Carpet Fashions Kahl's Carpet Fashions Kahl's Carpet Fashions Kahl's Carpet Fashions Kahl's Carpet Fashions Kahl's Carpet Fashions Kahl's Carpet Fashions As If By Magic Gallery As If By Magic Gallery As If By Magic Gallery As If By Magic Gallery

3635

Bagdad Tavern

Bagdad Tavern

Bagdad Tavern

Bagdad Tavern

Bagdad Tavern

Bagdad Tavern

Bagdad Tavern

Bagdad Tavern

Bagdad Tavern

Bagdad Tavern

Bagdad Tavern

Kids At Heart

Kids At Heart

Kids At Heart

3646

Avalon Antiques

Avalon Antiques

Oasis Antiques

Oasis Antiques

Oasis Antiques

Oasis Antiques

Oasis Antiques

Oasis Antiques

Oasis Antiques

Oasis Antiques

Oasis Antiques

Oasis Antiques

Blue Butterfly/

Moonstone

Blue Butterfly 
1980

1981

1982

1983 AAA Estate Sales

1984 AAA Estate Sales

1985 AAA Estate Sales

1986 AAA Estate Sales

1987 AAA Estate Sales

1988 AAA Estate Sales

1989 AAA Estate Sales

1990 AAA Estate Sales

1991 AAA Estate Sales

$1992 \quad \ldots$

$10 / 92 \ldots$
...

Slater Kinagy Co

Slater Construction

Slater Construction

Slater Construction

Slater Construction

Slater Construction

Slater Construction

Slater Construction

Slater Construction

Slater Construction

Slater Construction

Slater Construction

371429

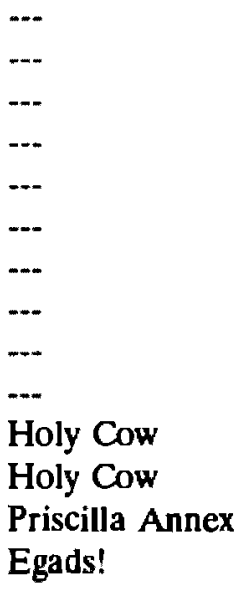

371435

1980

1981

1982

$1983 \quad \ldots$

$1984 \quad-$.

$1985 \quad \ldots$

1986 AAA Signs

1987 Narcotics Anonymous

1988 Narcotics Anonymous

$1989 \quad---$

$1990 \quad 37$ th Street Surprise

1991 37th Street Surprise

1992 Air Castle Plants

10/92 Baba Roots
371512

The Hair Hut

The Hair Hut

The Hair Hut

The Hair Hut

The Hair Hut

The Hair Hut

The Hair Hut

The Hair Hut

37th Street Salon

37th Street Salon

37th Street Salon

37th Street Salon

37th Street Salon

37th Street Salon
371431

$--$

$\cdots$

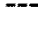

$\cdots$

$\cdots$

$\cdots$

$\cdots$

$\cdots$

Rose Sitka

Rose Sitka

Carolyn Locke

Carolyn Locke
371515

Republic Enterprise

Republic Enterprise

$\cdots$

Echo Theatre/Women Heart

Echo Theatre/Women Heart

Echo Theatre/Women Heart

Echo Theatre/Women Heart

Echo Theatre/One with Heart

Echo Theatre/One with Heart

Echo Theatre

Echo Theatre

Echo Theatre

Echo Theatre 
371520

1980

1981

1982

1983

1984

1985

1986

1987

1988

1989

1990

1991

1992

$10 / 92$

---

-..
Art and Literature Guild

Art and Literature Guild

Art and Literature Guild

George's Shoe Repair

The Cat's Meow

The Cat's Meow

The Cat's Meow

Tees, Sweats \& More

Piping Hot Pools

Hostelling Intl Travel
3701

Hawthorne Cycle and Toy

Antiques and Funk Furniture

Antiques and Funk Furniture

Antiques and Funk

The Boulevard Deli

Prego Gelateria

Prego Gelateria

Decadent Cafe Restaurant

Namaste Cafe

Oasis Cafe

Oasis Cafe

Oasis Cafe

Oasis Cafe

Oasis Cafe
3702

Bagdad Theatre

Bagdad Theatre

Bagdad Theatre

Bagdad Theatre

Bagdad Theatre

Bagdad Theatre

Bagdad Theatre

Bagdad Theatre

Bagdad Theatre

Bagdad Theatre

Bagdad Theatre

Bagdad Theatre

Bagdad Theatre

Bagdad Theatre

3720

George's Bagdad Shoes

George's Bagdad Shoes

George's Bagdad Shoes

George's Bagdad Shoes

George's Bagdad Shoes

First Stop Video Rental

First Stop Video Rental

First Stop Video Rental

First Stop Video Rental

First Stop Video Rental

First Stop Video Rental

First Stop Video

Bagdad Pub

Bagdad Pub
3723

1980

1981

1982

1983

1984

1985

1986

1987

1988

1989

1990

1991

1992

$10 / 92$
CAC Chinese Restaurant CAC Chinese Restaurant Mar's Restaurant Mar's Restaurant Mar's Restaurant Mar's Restaurant Mar's Restaurant Mar's Restaurant Mar's Restaurant Mar's Restaurant Mar's Restaurant Mar's Restaurant Mar's Restaurant Mar's Restaurant
3726

Dr Powell

Dr Powell

Dr Powell

Southeast Times

--
$\cdots$
$\cdots$
$\cdots$
$\cdots$
$\cdots$
$\cdots$
$\cdots$
$\cdots$
$\cdots$

\section{9}

Howard Jewelers Howard Jewelers The Uncommon Reader The Uncommon Reader Murder By The Book Murder By The Book Murder By The Book Murder By The Book Murder By The Book Murder By The Book Murder By The Book Murder By The Book Murder By The Book The Paper Moon 
3730

1980

1981

1982

1983

1984

1985

1986

1987

1988

1989

1990

1991

1992

$10 / 92$

3735

1980

1981

1982

1983

1984

1985

1986

1987

1988

1989

1990

1991

1992

$10 / 92$
3731

Ride On Skateboards

Ride On Skateboards

Organized Thrift

Northwood Books

Pastaworks

Pastaworks

Pastaworks

Pastaworks

Pastaworks

Pastaworks

Pastaworks

Pastaworks

Pastaworks

Pastaworks
3734

Antiques and Funk

Haggle Shop

Haggle Shop

Haggle Shop

Haggle Shop

Haggle Shop

Haggle Shop

Haggle Shop

Haggle Shop

Haggle Shop

Haggle Shop

Haggle Shop

Haggle Shop

Haggle Shop
3736

Bird's Suite Records

Bird's Suite Records

Bird's Suite Records

Bird's Suite Records

Bird's Suite Records

Bird's Suite Records

Bird's Suite Records

Bird's Suite Records

Bird's Suite Records

Bird's Suite Records

Bird's Suite Records

Bird's Suite Records

Bird's Suite Records

Bird's Suite Records

\section{9}

House of Linoleum House of Linoleum

--.

Bagdad Antiques

Bagdad Antiques

Bagdad Antiques

Bagdad Antiques

Bagdad Antiques

Powell's for Cooks

Powell's for Cooks

Powell's for Cooks

Powell's for Cooks

Powell's for Cooks

Powell's for Cooks
3739

$\begin{array}{ll}1980 & -- \\ 1981 & -- \\ 1982 & -- \\ 1983 & --- \\ 1984 & --- \\ 1985 & -- \\ 1986 & -- \\ 1987 & \text { AAA Garage Sales } \\ 1988 & --- \\ 1989 & \text { Salumeria di Carlo } \\ 1990 & \text { Salumeria di Carlo } \\ 1991 & \text { Salumeria di Carlo } \\ 1992 & \text { Salumeria di Carlo } \\ 10 / 92 & \text { Salumeria di Carlo }\end{array}$

3742

Hawthorne Audio Exchange Hawthorne Audio Exchange Hawthorne Audio Exchange Hawthorne Audio Exchange Hawthorne Audio Exchange Hawthorne Audio Exchange Hawthorne Audio Exchange Hawthorne Audio Exchange Hawthorne Audio Exchange Hawthorne Audio Exchange Hawthorne Audio Exchange Hawthorne Audio Exchange Hawthorne Audio Exchange Hawthorne Audio Exchange
3746

Nick's Coney Island Nick's Coney Island Nick's Coney Island Nick's Coney Island Nick's Coney Island Nick's Coney Island Nick's Coney Island Níck's Coney Island Nick's Coney Island Nick's Coney Island Nick's Coney Island Nick's Coney Island Nick's Coney Island Nick's Coney Island 


\section{7}

1980

1981

1982

1983

1984

1985

1986

1987

1988

1989

1990

1991

1992

$10 / 92$
Beaver Book Store

Beaver Book Store

Beaver Book Store

Beaver Book Store

Beaver Book Store

Beaver Book Store

Beaver Book Store

Beaver Book Store

Beaver Book Store

Beaver Book Store

Beaver Book Store

Beaver Book Store

Beaver Book Store

Powell's on Hawthorne
3757

Benj Franklin S\&L

Benj Franklin S\&L

Benj Franklin S\&L

Benj Franklin S\&L

Benj Franklin S\&L

Benj Franklin S\&L

Benj Franklin S\&L

Benj Franklin S\&L

Benj Franklin S\&L

Benj Franklin S\&L

Benj Franklin S\&L

Benj Franklin S\&L

Bank of America

Bank of America
3760

Fred's Sound of Music

Fred's Sound of Music

Fred's Sound of Music

Fred's Sound of Music

Fred's Sound of Music

Fred's Sound of Music

Fred's Sound of Music

Fred's Sound of Music

Fred's Sound of Music

Fred's Sound of Music

Fred's Sound of Music

Fred's Sound of Music

Fred's Sound of Music

Fred's Sound of Music
3766

1980

1981

1982

1983

1984

1985

1986

1987

1988

1989

1990

1991

1992

10,92
Chris Sci Reading Rm

Windy City

Windy City

Mt Tabor Sandwich

Mt Tabor Sandwich

Tabor Hill Cafe

Tabor Hill Cafe

Tabor Hill Cafe

Tabor Hill Cafe

Tabor Hill Cafe

Tabor Hill Cafe

Tabor Hill Cafe

Tabor Hill Cafe
3768

Galaxy records

Silver Lady Coins

Nostalgia Plus

-..

Jr Chamber Commerce

Grin 'n' Wear It

Grin 'n' Wear It

-.-
3782

First National Bank of Oregon First National Bank of Oregon First National Bank of Oregon First National Bank of Oregon First National Bank of Oregon First National Bank of Oregon First National Bank of Oregon First National Bank of Oregon First National Bank of Oregon First National Bank of Oregon First National Bank of Oregon First Interstate

First Interstate

First Interstate
3805

1980

1981

1982

1983

1984

1985

1986

1987

1988

1989

1990

1991

1992

$10 / 92$
Fred Meyer

Fred Meyer

Fred Meyer

Fred Meyer

Fred Meyer

Fred Meyer

Fred Meyer

Fred Meyer

Fred Meyer

Fred Meyer

Fred Meyer

Fred Meyer

Fred Meyer

Fred Meyer
3832

-..

Oregon Tractor

First Federal Savings

First Federal Savings

First Federal Savings

First Federal Savings

First Federal Savings

First Federal Savings

First Federal Savings

Pacific First Bank

Pacific First Bank

Pacific First Bank

Pacific First Bank

\section{2}

Sunnyside Masonic Temple Sunnyside Masonic Temple Sunnyside Masonic Temple Sunnyside Masonic Temple Sunnyside Masonic Temple Sunnyside Masonic Temple Sunnyside Masonic Temple Sunnyside Masonic Temple Sunnyside Masonic Temple Sunnyside Masonic Temple Sunnyside Masonic Temple Sunnyside Masonic Temple Sunnyside Masonic Temple Sunnyside Masonic Temple 


\section{APPENDIX B}

\section{ANNUAL BUSINESS MIX}

(Source: Cole Directories 1980-1992) 
All business in the study area between 1980 and 1992 are included in this appendix. Changes since the publication of the 1992 Cole Directory are listed under '10/92,' and accurate as of October 1st, 1992.

Addresses on side streets are prefixed by the street number. Odd numbers are on the north side of the street (and the west side of north-south streets), even numbers are on the south side of the street (and the east side of north-south streets).

Listings for the whole of Hawthorne Boulevard are available, in spreadsheet format, from the geography department at Portland State University. 
1980 Businesses

2800 Safeway

2804 State Liquor Control Commission

2805 Hare Krishna Temple

2828 Kentucky Fried Chicken

2942 Springtime Cleaners \& Laundry

2950 Plaid Pantry

3001 Tastee Freez Icecream

3006 Claudia's Tavern

3020 Remmington Keller

3028 Underwriters

3031 Playland Day Nursery

3032 Wisting's TV Repair

3106 Nelson Properties of Oregon

3129 Foster Business Systems

3130 AAA Service Inc

3130 Harris Uniforms

3140 Stereo World

3145 Doggie Delight

3202 General American Theatre Supply

3207 Perfect Upholstery and Supplies

3210 Elite Productions and Services

3239 Coit/Reese Cleaners

3257 The Knotting Chamber

3257 Life Environments green plants

3267 Ross Gearhart

3267 Regco Investors Inc

3279 Santana Hair Design

3279 The Woodcarver

3290 Attorney's Messenger

3315 Rose City Paper Box Inc

3327 Bedlion and Hellums Plumbing

3328 Tamak Inc

3335 Farmers Insurance

3335 Roxanne Russell

3335 Justice Co

3340 Hawthorne Beauty Salon

3341 Public Finance Corp

3343 Ancina Clinic

3354 Epicurean Delight

341432 JB Frederick Ltd

341527 Chapel of Light Church

341544 Christian Yellow Pages

3401 Showcase Music

3409 Sunrise Sheet Music

3415 Nearly New Shop

3420 Arctic Circle

3449 Danderoo's Auto Repair

351416 Heine Real Estate

351430 Emert (accountant)

3500 City Glass

3518 DJ's tavern

3522 Holland's Book Store

3525 McGee Blind's and Awnings

3526 Nina's Antiques
3530 The Whole Image

3532 Yestershades lampshades

3535 Scandia Spa

3537 Business controls of Oregon

3538 The Paper Moon

3541 Times and Seasons books

3545 Viennese Pastries

3549 The Midas Touch

3553 Melissa's Kitchen

3557 El Acapulco

3568 Larry's RSVP Bakery

3574 Adult Center

3590 Union Furniture Co

361428 Hawthorne Stereo

3616 East Portland Locksmith

3621 Combs and Scissors

3623 Valley Rental

3628 Lenny's Barber shop

3631 Kahl's Carpet Fashions

$3632 \mathrm{Tu}-\mathrm{Be}$ Tavern

3635 Bagdad Tavern

3638 ABC Piano Sales and service

3646 Avalon Antiques

371512 The Hair Hut

371515 Republic Enterprise

371520 Art and Literature Guild

3701 Hawthorne Cycle and Toy

3702 Bagdad Theatre

3713 Beaver Trading Post

3714 Fajardo's grocery and gifts

3720 George's Bagdad Shoes

3723 CAC Chinese Restaurant

3726 Dr. Powell

3729 Howard Jewelers

3730 Hawthorne Florist

3731 Ride On Skateboards

3734 Antiques and Funk

3735 Sally's Resale Boutique

3736 Bird's Suite Records

3739 House of Linoleum

3742 Hawthorne Audio Exchange

3746 Nick's Coney Island

3747 Beaver Book Store

3757 Benj Franklin S\&L

3760 Fred's Sound of Music

3766 Chr Sci Reading Room

3768 Galaxy records and tapes

3782 First National Bank of Oregon

3805 Fred Meyer

3815 William Sizemore (attorney)

3862 Sunnyside Masonic Temple 
1981 Businesses

2800 Safeway

2804 State Liquor Control Commission

2805 Hare Krishna Temple

2828 K F C

2942 Springtime Cleaners \& Laundry

2950 Plaid Pantry

3001 Tastee Freez Icecteam

3006 Claudia's

3020 Remmington Keller

3028 Underwriters

3031 Playland Day Nursery

3032 Wisting's TV

3106 Nelson Properties of Oregon

3130 AAA Service Inc

3130 Harris Uniforms

3140 Epic Speaker Co Inc

3145 Doggie Delight

3202 General American Theatre Supply

3207 Perfect Upholstery and Supplies

3239 Coit/Reese Cleaners

3257 The Knotting Chamber

3257 Life Environments green plants

3267 Ross Gearhart

3267 Regco Investors Inc

3279 Santana Hair Design

3279 The Woodcarver

3290 Attorney's Messenger Service

3315 Rose City Paper Box Inc

3327 Bedlion and Hellums Plumbing

3328 Tamak Inc

3335 Farmers Insurance

3335 Roxanne Russell

3335 Justice Co

3340 Hawthorne Beauty Salon

3341 Public Finance Corp

3343 Ancina Clinic

341432 JB Frederick Ltd

341527 Chapel of Light Church

341544 Arrow Typesetting

3401 Showcase Music

3409 Sunrise Sheet Music

3415 Nearly New Shop

3420 Arctic Circle

3449 Danderoo's Auto Repair

351416 Heine Real Estate

351430 Emert (accnt)

3500 City Glass

3508 Ted's Carpet Service

3518 DJ's tavern

3522 Holland's Book Store

3525 McGee Blind's and Awnings

3526 Nina's Antiques

3530 The Whole Image

3532 Yestershades handcrafted lampshades

3535 South Seas Tanning Studio
3537 Business controls

3538 The Paper Moon

3545 German Bakery and Deli

3549 The Midas Touch

3553 Melissa's Kitchen

3557 El Acapulco

3562 Hladini Enterprises

3568 Bread Spread

3574 Adult Center

3590 Union Fumiture Co

361428 Hawthome Stereo

3616 East Portland Locksmith

3621 Combs and Scissors

3623 NW Rent Systems

3628 Lenny's Barber shop

3631 Kahl's Carpet Fashions

3632 Tu-Be Tavern

3635 Bagdad Tavern

3638 ABC Piano Sales and service

3646 Avalon Antiques

371512 The Hair Hut

371515 Republic Enterprise

371520 Art and Lit Guild

3701 Antiques and Funk Furniture

3702 Bagdad Theatre

3713 Beaver Trading Post

3714 Fajardo's gro and gift store

3720 George's Bagdad Shoes

3723 CAC Chinese Restaurant

3726 Dr. Powell

3729 Howard Jewelers

3730 Hawthorne Florist

3731 Ride On Skateboards

3734 Haggle Shop

3735 Sally's Resale Boutique

3736 Bird's Suite Records

3739 House of Linoleum

3742 Hawthorne Audio Exchange

3746 Nick's Coney Island

3747 Beaver Book Store

3757 Benj Franklin S\&L

3760 Fred's Sound of Music

3782 First National Bank of Oregon

3805 Fred Meyer

3862 Sunnyside Masonic Temple 


\section{Businesses}

2800 Safeway

2804 State Liquor Control Commission

2805 resid

2828 K F C

2942 Springtime Cleaners \& Laundry

2950 Plaid Pantry

3001 Tastee Freez Icecream

3006 Claudia's

3020 Remmington Keller

3020 NW Surf+Sport Eq

3028 Underwriters

3031 Playland Day Nursery

3032 Wisting's TV

3106 Nelson Properties of Oregon

3129 Native American Rehab Association

3130 AAA Service Inc

3130 Harris Uniforms

3140 Attorney Messenger Co

3145 Doggie Delight

3202 General American Theatre Supply

3207 Perfect Upholstery and Supplies

3239 Coit/Reese Cleaners

3257 The Knotting Chamber

3257 Life Environments green plants

3267 Ross Gearhart

3267 Regco Investors Inc

3279 Santana Hair Design

3279 The Woodcarver

3315 Rose City Paper Box Inc

3327 Bedlion and Hellums Plumbing

3328 Tamak Inc

3335 Farmers Insurance

3335 Margie Holmes

3335 Justice Co

3340 Hairbourne

3343 Ancina Clinic

3344 Rollin Records

3354 Couchinis Restr

341527 Chapel of Light Church

341544 Arrow Typesetting

3401 Showcase Music

3401 Precision Guitar Repair

3409 Sunrise Sheet Music

3420 Arctic Circle

3449 Danderoo's Auto Repair

351416 Heine Real Estate

351430 Emert (accnt)

3500 City Glass

3508 Nearly New Shop

3518 DJ's tavern

3522 Holland's Book Store

3525 McGee Blind's and Awnings

3526 Nina's Antiques

3530 The Whole Image

3532 Yestershades handcrafted lampshades
3535 South Seas Tanning Studio

3537 Business controls of OR

3538 The Paper Moon

3541 Jean City

3545 German Bakery and Deli

3549 Michael's on the Boulevard

3553 Melissa's Kitchen

3557 El Acapulco

3562 Ruby's Antiques

3564 Fine and Fanciful Antiques

3568 Bread Spread

3574 Adult Center

3590 Union Furniture Co

361428 Hawthorne Stereo

3616 East Portland Locksmith

3621 Combs and Scissors

3623 OR Paralyzed Vets

3628 Lenny's Barber shop

3631 Kahl's Carpet Fashions

$3632 \mathrm{Tu}$-Be Tavern

3635 Bagdad Tavern

3638 ABC Piano Sales and service 3646 Oasis Antiques

371416 Slater Kinagy Co

371512 The Hair Hut

371520 Art and Lit Guild

3701 Antiques and Funk Furniture

3702 Bagdad Theatre

3713 Beaver Trading Post

3720 George's Bagdad Shoes

3723 Mar's Restaurant

3726 Dr. Powell

3729 The Uncommon Reader

3730 Hawthorne Florist

3731 Organized Thrift

3734 Haggle Shop

3735 Sally's Resale Boutique

3736 Bird's Suite Records

3742 Hawthorne Audio Exchange

3746 Nick's Coney Island

3747 Beaver Book Store

3757 Benj Franklin S\&L

3760 Fred's Sound of Music

3766 Windy City

3768 Silver Lady Coins

3782 First National Bank of Oregon

3805 Fred Meyer

3832 Or Tractr + Equip

3862 Sunnyside Masonic Temple 
1983 Businesses

2800 Safeway

2804 State Liquor Control Commission 2828 K F C

2942 Springtime Cleaners \& Laundry

3001 Tastee Freez Icecream

3006 Claudia's

3020 Remmington Keller

3024 Wistings TV

3028 Underwriters Laboratories Inc

3031 Playland Day Nursery

3032 Wisting's TV

3106 Nelson Properties of Oregon

3129 Native American Rehab Association

3130 AAA Service Inc

3130 Harris Uniforms

3140 Conifer Group

3145 Doggie Delight

3202 General American Theatre Supply

3207 Perfect Upholstery and Supplies

3239 Coit/Reese Cleaners

3257 The Knotting Chamber

3257 Liquid Assets coffee and wine

3257 Life Environments green plants

3267 Ross Gearhart

3267 Regco Investors Inc

3279 Santana Hair Design

3279 The Woodcarver

3315 Rose City Paper Box Inc

3327 Bedlion and Hellums Plumbing

3328 Tamak Inc

3328 W Faulkner Collect

3335 Farmers Insurance

3335 Margie Holmes

3335 Justice Co

3340 River City Seafood

3340 You're Looking Good

3343 Ancina Clinic

3354 Hawthorne Street Cafe

341432 West Coast Power

341544 Arrow Typesetting

3401 Showcase Music

3415 Desitrek Recording

3420 Arctic Circle

3449 Danderoo's Auto Repair

351416 Heine Real Estate

351430 Emert (accnt)

3500 City Glass

3508 Nearly New Shop

3518 Missouri Tavern

3522 Holland's Book Store

3525 McGee Blind's and Awnings

3526 Nina's Antiques

3530 The Whole Image

3532 Yestershades handcrafted lampshades

3535 South Seas Tanning Studio
3537 Business controls of OR

3538 The Paper Moon

3541 Tom's Second Time Around

3545 German Bakery and Deli

3553 Melissa's Kitchen

3557 El Acapulco

3562 Ruby's Antiques

3564 Fine and Fanciful Antiques

3568 Sunnyside Up

3574 Adult Center

3590 Union Furniture Co

361428 Hawthorne Stereo

3616 East Portland Locksmith

3621 Combs and Scissors

3623 OR Paralyzed Vets

3628 Lenny's Barber shop

3631 Kahl's Carpet Fashions

3632 Tu-Be Tavern

3635 Bagdad Tavern

3638 Ed's Piano Service

3646 Oasis Antiques

3646 AAA Estate Sales

371416 Slater Construction

371416 Human Affairs lnc

371512 The Hair Hut

3701 Antiques and Funk

3701 The Boulevard Deli

3702 Bagdad Theatre

3713 Beaver Trading Post

3720 George's Bagdad Shoes

3723 Mar's Restaurant

3726 SE Times

3729 The Uncommon Reader

3730 Hawthorne Florist

3731 Northwood Books

3734 Haggle Shop

3735 Sally's Resale Boutique

3736 Bird's Suite Records

3739 Bagdad Antiques/Furniture

3742 Hawthorne Audio Exchange

3746 Nick's Coney Island

3747 Beaver Book Store

3757 Benj Franklin S\&L

3760 Fred's Sound of Music

3766 Windy City

3768 Nostalgia Plus

3782 First National Bank of Oregon

3805 Fred Meyer

3832 First Federal Savings

3862 Sunnyside Masonic Temple 
1984 Businesses

2800 Safeway

2804 State Liquor Control Commission

2828 K F C

2942 Springtime Cleaners \& Laundry

3001 Tastee Freez Icecream

3006 Claudia's

3020 Native American Rehab

3024 Wistings TV

3028 Supermicro computer

3031 Playland Day Nursery

3032 Mister Michael's Deli

3106 Nelson Properties of Oregon

3130 AAA Service Inc

3130 Harris Uniforms

3140 Conifer Group

3145 Doggie Delight

3207 Perfect Upholstery and Supplies

3239 Coit/Reese Cleaners

3257 The Knotting Chamber

3257 Liquid Assets coffee and wine

3257 the Golden Swan

3267 Ross Gearhart

3267 Regco Investors Inc

3279 Graystone Gallery

3315 Rose City Paper Box Inc

3327 Bedlion and Hellums Plumbing

3328 Tamak Inc

3328 W Faulkner Collect

3335 Farmers Insurance

3335 Margie Holmes

3335 Justice Co

3340 You're Looking Good

3343 Ancina Clinic

3354 Hawthorne Street Cafe

341432 West Coast Power

341544 Arrow Typesetting

3401 Showcase Music

3401 Oregon Bass Company

3415 Desitrek Recording

3420 Arctic Circle

3449 Danderoo's Auto Repair

351416 Heine Real Estate

351430 Michael Emert

3500 City Glass

3508 Nearly New Shop

3518 Missouri Tavern

3522 Holland's Book Store

3525 McGee Blind's and Awnings

3526 Nina's Antiques

3532 Yestershades handcrafted lampshades

3537 Business controls of OR

3538 The Paper Moon

3541 Somewhere in Time Clothier

3545 German Bakery and Deli

3549 Rose City Art Center
3553 Macheesmo Mouse

3556 Immdt CVR Ctn Dig

3557 Don Juan's Mexican cuisine

3562 Hawthorne Coffee Merchants

3564 Fine and Fanciful Antiques

3568 Sunnyside Up

3574 Adult Center

3580 Parry Center Thrift Shop

3590 Ruby's Antiques

361428 Hawthorne Stereo

3610 Bread \& Ink Cafe

3616 East Portland Locksmith

3621 Combs and Scissors

3623 OR Paralyzed Vets

3628 Lenny's Barber shop

3631 Kahl's Carpet Fashions

3632 Tu-Be Tavern

3635 Bagdad Tavern

3638 Frameworks picture frames

3646 Oasis Antiques

3646 AAA Estate Sales

371416 Slater Construction

371416 Human Affairs Inc

371512 The Hair Hut

371515 Echo Theatre/Women Heart

3702 Bagdad Theatre

3713 Beaver Trading Post

3720 George's Bagdad Shoes

3723 Mar's Restaurant

3729 Murder By The Book

3730 Hawthorne Florist

3731 Pastaworks

3734 Haggle Shop

3735 Sally's Resale Boutique

3736 Bird's Suite Records

3739 Bagdad Antiques and Furn Exchange

3742 Hawthorne Audio Exchange

3746 Nick's Coney Island

3747 Beaver Book Store

3757 Benj Franklin S\&L

3760 Fred's Sound of Music

3766 Mt Tabor Sandwich

3782 First National Bank of Oregon

3805 Fred Meyer

3832 First Federal Savings

3862 Sunnyside Masonic Temple 
1985 Businesses

2800 Safeway

2804 State Liquor Control Commission

2828 K F C

2928 Lorretta's Banquet

2942 Springtime Cleaners \& Laundry

2950 Lee's Express Grocery

3006 Claudia's

3020 Native American Rehab

3024 Wistings TV

3031 AYH

3032 Mister Michael's Deli

3106 Nelson Properties of Oregon

3130 AAA Service Inc

3130 Harris Uniforms

3140 Conifer Group

3145 Doggie Delight

3203 Harry's Original Movie

3207 Perfect Upholstery and Supplies

3239 Coit/Reese Cleaners

3257 The Knotting Chamber

3257 Liquid Assets coffee and wine

3257 the Golden Swan

3267 Ross Gearhart

3267 Regco Investors Inc

3268 Gene's Nursing Service

3279 Graystone Gallery

3315 Rose City Paper Box Inc

3327 Bedlion and Hellums Plumbing

3328 Tamak Inc

3328 W Faulkner Collect

3335 Farmers Insurance

3335 Margie Holmes

3335 Justice Co

3340 You're Looking Good

3341 Eastside Photo

3343 Ancina Clinic

3354 Hawthorne Street Cafe

341432 Sprr Stg and Lighting Inc

341544 Arrow Typesetting

3401 Showcase Music

3401 Oregon Bass Company

3415 Desitrek Recording

3420 Arctic Circle

3449 Danderoo's Auto Repair

351416 Heine Real Estate

351430 Emert (accnt)

3500 City Glass

3508 Nearly New Shop

3518 Missouri Tavern

3522 Who cares

3525 McGee Blind's and Awnings

3526 Nina's Antiques

3532 Yestershades

3535 Simon Lake

3537 Business controls of OR
3538 The Paper Moon

3541 Somewhere in Time Clothier 3545 Franz German Bakery and Deli 3549 Rose City Art Center

3553 Macheesmo Mouse

3556 Immdt CVR Ctn Dig

3557 Don Juan's Mexican cuisine

3562 Hawthorne Coffee Merchants

3568 Sunnyside Up

3580 Parry Center Thrift Shop

3590 Ruby's Antiques

361428 Hawthorne Stereo

3610 Bread \& Ink Cafe

3616 East Portland Locksmith

3620 Scarlet Letter antiques

3621 Combs and Scissors

3624 Orpheus Music Compact Discs

3628 Lenny's Barber shop

3631 Kahl's Carpet Fashions

$3632 \mathrm{Tu}$-Be Tavern

3635 Bagdad Tavern

3638 Frameworks picture frames

3646 Oasis Antiques

3646 AAA Estate Sales

371416 Slater Construction

371416 Human Affairs Inc

371512 The Hair Hut

371515 Echo Theatre/Women Heart

371520 George's Shoe Repair

3701 Prego Gelateria

3702 Bagdad Theatre

3713 Beaver Trading Post

3720 First Stop Video Rental

3723 Mar's Restaurant

3729 Murder By The Book

3730 Hawthorne Florist

3731 Pastaworks

3734 Haggle Shop

3735 Sally's Resale Boutique

3736 Bird's Suite Records

3739 Bagdad Antiques and Furn Exchange

3742 Hawthorne Audio Exchange

3746 Nick's Coney Island

3747 Beaver Book Store

3757 Benj Franklin S\&L

3760 Fred's Sound of Music

$3766 \mathrm{Mt}$ Tabor Sandwich

$3768 \mathrm{Jr}$ Chamber Commerce

3782 First Interstate

3805 Fred Meyer

3832 First Federal Savings

3862 Sunnyside Masonic Temple 


\section{Businesses}

2800 Safeway

2804 State Liquor Control Commission

2828 K F C

2928 Lorretta Banquets

2942 Springtime Cleaners \& Laundry

2950 Lee's Express Grocery

3001 Taco Loco

3006 Claudia's

3020 Native American Rehab

3024 Wistings TV

3031 American Youth Hostel

3032 Mister Michael's Deli

3106 Nelson Properties of Oregon

3129 Hawthorne Boulevard Books

3130 AAA Service Inc

3130 Harris Uniforms

3140 Conifer Group

3145 Doggie Delight

3207 Perfect Upholstery and Supplies

3239 Coit/Reese Cleaners

3257 The Knotting Chamber

3257 Liquid Assets coffee and wine

3257 the Golden Swan

3267 Ross Gearhart

3267 Regco Investors Inc

3279 Graystone Gallery

331525 Devone Divine

3315 Rose City Paper Box Inc

3327 Bedlion and Hellums Plumbing

3328 Tamak Inc

3328 The Perfume House

3328 W Faulkner Collect

3335 Farmers Insurance

3335 Margie Holmes

3335 Justice Co

3340 You're Looking Good

3341 Eckankr Cascade

3343 Ancina Clinic

3354 Hawthorne Street Cafe

341432 Sprr Stg and Lighting Inc

341544 Arrow Typesetting

3401 Showcase Music

3401 GTS Electronics

3415 Desitrek Recording

3420 Arctic Circle

3449 Danderoo's Auto Repair

351416 Heine Real Estate

351430 Emert CPA

3500 City Glass

3508 Nearly New Shop

3522 Who cares

3525 McGee Blind's and Awnings

3526 Nina's Antiques

3530 Delamare Productions

3532 Yestershades handcrafted lampshades
3537 Business controls of OR

3538 The Paper Moon

3541 Sew What

3541 Illusionary Designs theatrical makeup

3545 Sarah's Cookies

3549 Rose City Art Center

3553 Macheesmo Mouse

3556 Cotton Delight

3557 Don Juan's Mexican cuisine

3562 Hawthorne Coffee Merchants

3568 Sunnyside Up

3580 Parry Center Thrift Shop

3590 Ruby's Antiques

361428 Hawthorne Stereo

3610 Bread \& Ink Cafe

3616 East Portland Locksmith

3621 Combs and Scissors

3624 Orpheus Music Compact Discs

3628 Lenny's Barber shop

3631 Kahl's Carpet Fashions

3632 Tu-Be Tavern

3635 Bagdad Tavern

3638 Frameworks picture frames

3646 Oasis Antiques

3646 AAA Estate Sales

371416 Slater Construction

371416 Spirit of Oregon

371435 AAA Signs

371512 The Hair Hut

371515 Echo Theatre/Women Heart

3701 Prego

3702 Bagdad Theatre

3713 Beaver Trading Post

3720 First Stop Video Rental

3723 Mar's Restaurant

3729 Murder By The Book

3730 Hawthorne Florist

3731 Pastaworks

3734 Haggle Shop

3736 Bird's Suite Records

3739 Bagdad Antiques and Furn Exchange

3742 Hawthorne Audio Exchange

3746 Nick's Coney Island

3747 Beaver Book Store

3757 Benj Franklin S\&L

3760 Fred's Sound of Music

3766 Tabor Hill Cafe

3768 Grin n Wear It

3782 First National Bank of Oregon

3805 Fred Meyer

3832 First Federal Savings

3862 Sunnyside Masonic Temple 
1987 Businesses

2800 Safeway

2828 K F C

2942 Springtime Cleaners \& Laundry

2950 Lee's Express Grocery

3001 Mister Burger

3006 Claudia's

3020 Native American Rehab

3031 American Youth Hostel

3032 Mister Michael's Deli

3106 Nelson Properties of Oregon

3129 Hawthorne Boulevard Books

3130 AAA Service Inc

3140 Conifer Group

3145 Doggie Delight

3207 Perfect Upholstery and Supplies

3239 Coit/Reese Cleaners

3240 Wally's Ribs

3257 The Knotting Chamber

3257 Liquid Assets coffee and wine

3267 Ross Gearhart

3267 Regco Investors Inc

3279 Graystone Gallery

331525 Devone Divine

3315 Rose City Paper Box Inc

3327 Bedlion and Hellums Plumbing

3328 Tamak Inc

3328 The Perfume House

3328 W Faulkner Collect

3335 Farmers Insurance

3335 Margie Holmes

3335 Justice Co

3340 Guitar Crazy

3340 You're Looking Good

3341 Eckankr Cascade

3343 Ancina Clinic

3354 Hawthorne Street Cafe

341432 Sprr Stg and Lighting Inc

341544 Arrow Typesetting

3401 Showcase Music

3401 GTS Electronics

3415 Desitrek Recording

3420 Arctic Circle

3449 Danderoo's Auto Repair

341416 Heine Real Estate

341430 Emert CPA

3500 City Glass

3508 Nearly New Shop

3519 Peace

3522 Artichoke Music

3525 McGee Blind's and Awnings

3526 Timeless Treasures by $T$ Marie

3530 Delamare Productions

3532 Yestershades handcrafted lampshades

3535 Della's Deco Ware

3537 Business controls of OR
3538 The Paper Moon

3541 Visible Impact

3541 Illusionary Designs theatrical makeup

3545 Bowers Bakery and Deli

3553 Macheesmo Mouse

3556 El Mundo

3557 Don Juan's Mexican cuisine

3562 Hawthorne Coffee Merchants

3568 Sunnyside Up

3580 Parry Center Thrift Shop

3590 Ruby's Antiques

361428 Hawthorne Stereo

3610 Bread \& Ink Cafe

3616 East Portland Locksmith

3621 Combs and Scissors

3623 Crocodile Records

3624 Orpheus Music Compact Discs

3628 Lenny's Barber shop

3631 Kahl's Carpet Fashions

3632 Tu-Be Tavern

3635 Bagdad Tavern

3638 Frameworks picture frames

3646 Oasis Antiques

3646 AAA Estate Sales

371416 Slater Construction

371420 Guaranty Construction

371435 Narcotics Anonymous

371512 The Hair Hut

371515 Echo Theatre/Women Heart

371520 The Cat's Meow

3701 Decadent Cafe Restaurant

3702 Bagdad Theatre

3713 Beaver Trading Post

3720 First Stop Video Rental

3723 Mar's Restaurant

3729 Murder By The Book

3730 Hawthorne Florist

3731 Pastaworks

3734 Haggle Shop

3736 Bird's Suite Records

3739 Bagdad Antiques and Furn Exchange

3739 AAA Garage Sales

3742 Hawthorne Audio Exchange

3746 Nick's Coney Island

3747 Beaver Book Store

3757 Benj Franklin S\&L

3760 Fred's Sound of Music

3766 Tabor Hill Cafe

3768 Grin n Wear It

3782 First National Bank of Oregon

3805 Fred Meyer

3832 First Federal Savings 
1988 Businesses

2800 Safeway

2804 Liquor Store

2828 K F C

2942 Springtime Cleaners \& Laundry

2950 Lee's Express Grocery

3001 Y's Burger

3006 Claudia's

3020 Native American Rehab

3031 American Youth Hostel

3032 Mister Michael's Deli

3106 Nelson Properties of Oregon

3129 Hawthorne Boulevard Books

3130 AAA Service Inc

3130 Neon Art and Tube Bending

3140 Conifer Group

3145 Lanai Cafe

3207 Perfect Upholstery and Supplies

3239 Coit/Reese Cleaners

3257 The Knotting Chamber

3257 Liquid Assets coffee and wine

3267 Ross Gearhart

3267 Regco Investors Inc

3279 Graystone Gallery

331525 Devone Divine

3315 Rose City Paper Box Inc

3327 Bedlion and Hellums Plumbing

3328 Tamak Inc

3328 The Perfume House

3328 W Faulkner Collect

3335 Four Star Productions

3335 Margie Holmes

3335 Justice Co

3340 Guitar Crazy

3340 You're Looking Good

3341 Eckankr Cascade

3343 Ancina Clinic

3354 Hawthorne Street Cafe

341544 Arrow Typesetting

3401 Showcase Music

3401 GTS Electronics

3415 Desitrek Recording

3420 Arctic Circle

3449 Danderoo's Auto Repair

351416 Heine Real Estate

351416 Emert CPA

3500 City Glass

3508 Nearly New Shop

3522 Artichoke Music

3525 McGee Blind's and Awnings

3526 Timeless Treasures by $T$ Marie

3530 Delamare Productions

3532 Yestershades lampshades

3535 Grin n Wear It

3537 Business controls of OR

3538 The Paper Moon
3541 Visible Impact

3541 Illusionary Designs theatrical makeup

3545 Bowers Bakery and Deli

3549 Peace

3553 Macheesmo Mouse

3556 El Mundo

3558 Portland Central American

3558 Greenpeace

3562 Hawthorne Coffee Merchants

3568 Sunnyside Up

3580 Parry Center Thrift Shop

3590 Ruby's Antiques

361428 Hawthorne Stereo

3610 Bread \& Ink Cafe

3616 East Portland Locksmith

3621 Combs and Scissors

3623 Crocodile Records

3624 Orpheus Music Compact Discs

3628 Lenny's Barber shop

3631 Kahl's Carpet Fashions

$3632 \mathrm{Tu}-\mathrm{Be}$ Tavern

3635 Bagdad Tavern

3638 Escential Lotions

3646 Oasis Antiques

3646 AAA Estate Sales

371416 Slater Construction

371435 Narcotics Anonymous

371512 37th Street Salon

371515 Echo Theatre/One with Heart

371520 The Cat's Meow

3701 Namaste Cafe

3702 Bagdad Theatre

3713 Beaver Trading Post

3720 First Stop Video Rental

3723 Mar's Restaurant

3729 Murder By The Book

3730 Hawthorne Florist

3731 Pastaworks

3734 Haggle Shop

3736 Bird's Suite Records

3739 Powells Books

3742 Hawthorne Audio Exchange

3746 Nick's Coney Island

3747 Beaver Book Store

3757 Benj Franklin S\&L

3760 Fred's Sound of Music

3766 Tabor Hill Cafe

3782 First National Bank of Oregon

3805 Fred Meyer

3832 First Federal Savings

3862 Sunnyside Masonic Temple 


\section{Businesses}

2800 Safeway

2804 State Liquor Control Commission

2805 Hawthorne Hacienda Group Home 2828 K F C

2942 Springtime Cleaners \& Laundry

2950 Lee's Express Grocery

3001 Y's Burger

3006 Claudia's

3020 Native American Rehab

3031 American Youth Hostel

3032 Mister Michael's Deli

311411 Hawthorne Technology

3106 Nelson Properties of Oregon

3129 Hawthorne Boulevard Books

3130 AAA Service Inc

3130 Neon Art and Tube Bending

3140 Conifer Group

3145 Lanai Cafe

3207 Perfect Upholstery and Supplies

3239 Coit/Reese Cleaners

3257 The Knotting Chamber

3267 Ross Gearhart

3267 Regco Investors Inc

3279 Graystone Gallery

1525 Devone Divine

3315 Rose City Paper Box Inc

3327 Bedlion and Hellums Plumbing

3328 Tamak Inc

3328 The Perfume House

3328 W Faulkner Collect

3335 Margie Holmes

3335 Justice Co

3340 Guitar Crazy

3341 Eckankr Cascade

3343 Ancina Clinic

3354 Hawthorne Street Cafe

1544 Arrow Typesetting

3401 Showcase Music

3401 GTS Electronics

3415 Desitrek Recording

3420 Arctic Circle

3449 Danderoo's Auto Repair

1416 Heine Real Estate

1430 Emert CPA

3500 City Glass

3508 Nearly New Shop

3522 Artichoke Music

3525 McGee Blind's and Awnings

$3530 \mathrm{~L}$ Milam Illustrations

3530 Second Story Books

3535 Grin n Wear It

3537 Business controls of OR

3538 The Paper Moon

3541 Visible Impact

3541 Illusionary Designs theatrical makeup
3545 Bowers Bakery and Deli

3549 A D Quan Vietnamese

3553 Macheesmo Mouse

3556 El Mundo

3558 Or Cispes

3562 Hawthorne Coffee Merchants

3568 Sunnyside Up

3574 Adult Center

3580 Parry Center Thrift Shop

3590 Ruby's Antiques

361428 Hawthorne Stereo

3610 Bread \& Ink Cafe

3616 East Portland Locksmith

3621 Cutting Crew

3623 Crocodile Records

3624 Orpheus Music Compact Discs

3628 Lenny's Barber shop

3631 Kahl's Carpet Fashions

$3632 \mathrm{Tu}-\mathrm{Be}$ Tavern

3635 Bagdad Tavern

3638 Escential Lotions

3646 Oasis Antiques

3646 AAA Estate Sales

371416 Slater Construction

371512 37th Street Salon

371515 Echo Theatre/One with Heart

371520 The Cat's Meow

3701 Oasis Cafe

3702 Bagdad Theatre

3713 Beaver Trading Post

3720 First Stop Video Rental

3723 Mar's Restaurant

3729 Murder By The Book

3730 Hawthorne Florist

3731 Pastaworks

3734 Haggle Shop

3736 Bird's Suite Records

3739 Powells Books

3739 Salumeria di Carlo

3742 Hawthorne Audio Exchange

3746 Nick's Coney Island

3747 Beaver Book Store

3757 Benj Franklin S\&L

3760 Fred's Sound of Music

3766 Tabor Hill Cafe

3782 First National Bank of Oregon

3805 Fred Meyer

3832 First Federal Savings

3862 Sunnyside Masonic Temple 
1990 Businesses

2800 Safeway

2804 Liquor Store

2828 K F C

2942 Springtime Cleaners \& Laundry

2950 Lee's Express Grocery

3001 House of Malaka

3006 Claudia's

3020 Karate for Women

3024 Angie's Candies and Cafe

3024 A Toz Natural Nutrition

3031 American Youth Hostel

3032 Mister Michael's Deli

311411 Hawthorne Technology

3106 Nelson Properties of Oregon

3129 Hawthorne Boulevard Books

3130 AAA Service Inc

3130 Neon Art and Tube Bending

3140 Conifer Group

3145 Lanai Cafe

3207 Perfect Upholstery and Supplies

3239 Coit/Reese Cleaners

3240 Best Rentals

3257 The Knotting Chamber

3267 Ross Gearhart

3267 Regco Investors Inc

3279 Graystone Gallery

331525 Devone Divine

3315 Rose City Paper Box Inc

3327 Bedlion and Hellums Plumbing

3328 Tamak Inc

3328 The Perfume House

3328 W Faulkner Collect

3335 Just Us Trave!

3335 Margie Holmes

3335 Justice Co

3341 Eckankr Cascade

3343 Ancina Clinic

3354 Hawthorne Street Cafe

341544 Arrow Typesetting

3401 Showcase Music

3401 GTS Electronics

3415 Desitrek Recording

3420 Arctic Circle

3433 Nibbles

3435 Priscilla Ann

3443 NW Futon

3445 Man's Best Friend

351416 Heine Real Estate

351430 Emert CPA

3500 City Glass

3508 Nearly New Shop

3522 Artichoke Music

3525 McGee Blind's and Awnings

3530 Larry Milam Illustration

3530 Peter R. Diehl
3530 Second Story Books

3535 Grin n Wear It

3537 Business controls of OR

3538 The Cat's Meow

3541 Visible Impact

3541 Illusionary Designs theatrical makeup

3545 Bowers Bakery and Deli

3549 A D Quan Vietnamese

3553 Macheesmo Mouse

3556 El Mundo

3557 Hawthorne Health Care

3558 Or Cispes

3562 Hawthorne Coffee Merchants

3566 Cup \& Saucer Cafe

3568 Sunnyside Up

3590 Ruby's Antiques

361428 Hawthorne Stereo

3610 Bread \& Ink Cafe

3614 Linda Loving Florist

3616 East Portland Locksmith

3621 Cutting Crew

3623 Crocodile Records

3628 Lenny's Barber shop

3631 As If By Magic

3632 Tu-Be Tavern

3633 Presents of Mind

3635 Bagdad Tavern

3638 Escential Lotions

3646 Oasis Antiques

3646 AAA Estate Sales

371416 Slater Construction

371429 Holy Cow

371431 Rose Sitka

371435 37th Street Surprise

371512 37th Street Salon

371515 Echo Theatre

371520 Tees, Sweats \& More

3701 Oasis Cafe

3702 Bagdad Theatre

3713 Beaver Trading Post

3720 First Stop Video Rental.

3723 Mar's Restaurant

3729 Murder By The Book

3730 Hawthorne Florist

3731 Pastaworks

3734 Haggle Shop

3736 Bird's Suite Records

3739 Powells Books

3739 Salumeria di Carlo

3742 Hawthorne Audio Exchange

3746 Nick's Coney Island

3747 Beaver Book Store

3757 Benj Franklin S\&L

3760 Fred's Sound of Music

3766 Tabor Hill Cafe 
3782 First National Bank of Oregon

3805 Fred Meyer

3832 Pacific First Bank

3862 Sunnyside Masonic Temple 
1991 Businesses

2800 Safeway

2804 Hawthorne Liquor Store

2828 Kentucky Fried Chicken

2942 Springtime Thrifty Cleaners

2950 Express Grocery

3001 House of Malaka

3006 Claudia's

3020 Spirit and Spin Inc

3020 Vinyl Industries

3024 Angies Candies and Cafe

3028 1\&2 Dollar Video

3031 American Youth Hostel

3032 Mr. Michael's Deli

311411 Hawthorne Technology

3106 Nelson Properties of Oregon

3129 Hawthorne Boulevard Books

3130 Clark's AAA Repair

3130 Neon Art School

3140 The Conifer Group (real estate)

3145 Lanai Restaurant

3200 Devine's Sew Happy (alterations)

3202 Wildflowers on Hawthorne

3204 Savvy Plus

3206 What Goes Around?

3207 Perfect Fit Auto Upholstery

3208 In Her Image Gallery

3239 Coit/Reese Cleaners

3240 Crone Magic (A)

3240 Hair Forte (B)

3257 The Knotting Chamber

3267 Gearhart \& Gearhart

3267 Regco

3279 Graystone Gallery

3315 C.Y.'s Shades and Collectibles

3327 Hellums Mechanical Inc.

3328 Tamak Inc

3328 The Perfume House

3328 W Faulkner Collect

3335 Just Us Travel

3335 Margie Holmes

3335 Justice Co

3341 Eckankar Cascade

3343 Ancina Chiropractic Clinic

3354 Hawthorne Street Cafe

341544 Arrow Typesetting

3401 Showcase Music \& Sound, Inc.

3401 GTS Electronics

3415 Desitrek

3420 Arctic Circle

3433 Nibbles on Hawthorne

3435 Pricilla Ann's

3443 Northwest Futon Company

3445 Man's Best Friend

351430 Emert CPA

3500 City Glass
3508 Nearly New Shop

3522 Artichoke Music

3525 McGee Awnings

3526 Artichoke

3530 Larry Milam Illustration

3530 Peter R. Diehl

3530 Second Story Books

3534 Buttertoe's Cards and Gifts

3535 Grin and Wear It

3537 Business Controls

3538 The Cat's Meow

3541 Visible Impact Resale Fashion

3545 Bowers Bakery and Deli

3549 Fu Jin Restaurant

3553 Macheesmo Mouse

$3556 \mathrm{El}$ Mundo, For Women

3557 Hawthorne Healthcare Center

3558 lllusionary Design

3558 Cispes

3562 The Hawthorne Coffee Merchant

3566 Cup and Saucer

3568 Sunnyside Up Bakery

3574 Hardtimes East Video Store

3590 Ruby's Antiques and Gifts

361428 Hawthorne Stereo

3610 Bread \& Ink Cafe

3614 Linda Loving Florist

3616 East Portland Locksmith

3621 Cutting Crew

3623 Crocodile Records

3628 Len's barber

3631 As If By Magic Gallery

3632 Tu-Be Tavern

3633 Presents of Mind

3635 Kids At Heart

3638 Escential

3639 Starbucks Coffee Co.

3646 Oasis Antiques

3646 AAA Estate Sales

371416 Slater Construction

371429 Holy Cow

371431 Rose Sitka

37 1435 37th Street Surprise

371512 37th Street Salon

371515 Echo Theatre

3701 Oasis Cafe

3702 Bagdad

3713 Beaver Trading

3720 First Stop Video

3723 Mar's Restaurant

3729 Murder By The Book

3729 The Paper Moon

3730 Hawthorne Florist

3731 Pastaworks

3734 Haggle Shop 
3736 Bird's Suite

3739 Powell's Books for Cooks

3739 Salumeria di Carlo

3742 Hawthorne Audio Exchange

3746 Nick's Coney Island

3747 Beaver Book Store

3757 Benj Franklin

3760 Fred's Sound of Music

3766 Tabor Hill Cafe

3782 First Interstate

3805 Fred Meyer's

3832 Pacific First Bank

3862 Sunnyside Masonic Temple 
1992 Businesses

2800 Safeway

2804 Hawthorne Liquor Store

2828 Kentucky Fried Chicken

2942 Springtime Thrifty Cleaners

2950 Express Grocery

3001 RJ's All-American Restaurant

3006 Claudia's

3020 Spirit and Spin Inc

3020 Vinyl Industries

3020 Sunnyside Counseling Center

3024 As You Like It

3028 Mr. D's Video

3031 American Youth Hostel

$3032 \mathrm{Mr}$. Michael's Catering

311411 Hawthorne Technology

311521 Karate for Women

3106 Nelson Properties of Oregon

3129 Hawthorne Boulevard Books

3130 Clark's AAA Repair

3130 Neon Art School

3140 The Conifer Group (real estate)

3145 Lanai Restaurant

3200 Devine's Sew Happy (alterations)

3202 Wildflowers on Hawthorne

3204 Savy Plus

3206 What Goes Around?

3207 Perfect Fit Auto Upholstery

3208 In Her Image Gallery

3239 Coit/Reese Cleaners

3240 Crone Magic (A)

3240 Hair Forte (B)

3257 The Knotting Chamber

3267 Gearhart \& Gearhart

3267 Regco

3279 Graystone Gallery

3315 Robert Welsh

3327 Hellums Mechanical Inc.

3328 Tamak Inc

3328 The Perfume House

3328 W Faulkner Collect

3335 Just Us Travel

3335 Margie Holmes

3335 Justice Co

3340 Vitna Print and Stationary

3341 Portland Eckankar Center

3343 Ancina Chiropractic Clinic

3344 Think Good Thoughts

3354 Hawthorne Street Cafe

341544 Arrow Typesetting

3401 Showcase Music \& Sound, Inc.

3415 Desitrek

3420 Arctic Circle

3433 Nibbles on Hawthorne

3435 Pricilla Ann's

3443 Northwest Futon Company
3445 Man's Best Friend

351430 Emert CPA

3500 City Glass

3508 Nearly New Shop

3518 Mark's Hawthorne Pub

3522 Artichoke Music

3525 McGee Awnings

3526 Artichoke

3530 Larry Milam Illustration

3530 Peter R. Diehl

3530 Second Story Books

3530 David Delamare Artwork

3534 Buttertoe's Cards and Gifts

3535 Grin and Wear It

3538 The Cat's Meow

3541 Visible Impact Resale Fashion

3545 Bowers Bakery and Deli

$3549 \mathrm{Fu}$ Jin Restaurant

3553 Macheesmo Mouse

$3556 \mathrm{El}$ Mundo, For Women

3557 Hawthorne Healthcare Center

3558 Illusionary Design

3558 Bauske \& Eller Attorneys

3558 Portland Central American

3562 The Hawthorne Coffee Merchant

3566 Cup and Saucer

3568 Sunnyside Up Bakery

3574 Hardtimes East Video Store

3580 Ruby's Antiques and Gifts

3590 Ruby's Antiques and Gifts

361428 Hawthorne Stereo

3610 Bread \& Ink Cafe

3614 Linda Loving Florist

3616 East Portland Locksmith

3621 Cutting Crew

3623 Crocodile Records

3628 Len's barber

3631 As If By Magic Gallery

3632 Tu-Be Tavern

3633 Presents of Mind

$3635 \mathrm{Kids}$ At Heart

3638 Escential

3639 Starbucks Coffee Co.

3646 Blue Butterfly, Moonstone

371416 Slater Construction

371420 D.Morrison Books

371431 Carolyn Locke

371512 37th Street Salon

371515 Echo Theatre

371520 Piping Hot Pools

3701 Oasis Cafe

3702 Bagdad

3713 Sorel Vintages Ltd.

3720 Bagdad Pub

3723 Mar's Restaurant 
3729 Murder By The Book

3729 The Paper Moon

3730 Hawthorne Florist

3731 Pastaworks

3734 Haggle Shop

3736 Bird's Suite

3739 Powell's Books for Cooks

3739 Salumeria di Carlo

3742 Hawthorne Audio Exchange

3746 Nick's Coney Island

3747 Beaver Book Store

3757 Bank of America

3760 Fred's Sound of Music

3766 Tabor Hill Cafe

3782 First Interstate

3805 Fred Meyer's

3832 Pacific First Bank

3862 Sunnyside Masonic Temple 
2800 Safeway

2804 Hawthorne Liquor Store

2942 Springtime Thrifty Cleaners

2950 Express Grocery

3001 At The Hop

3006 Claudia's

3020 Spirit and Spin Inc.

3020 Vinyl Industries

3020 Sunnyside Counseling Center

3031 American Youth Hostel

311521 Karate for Women

3106 Nelson Properties of Oregon

3129 Hawthorne Boulevard Books

3130 Clark's AAA Repair

3130 Neon Art School

3140 The Conifer Group

3145 Lanai Restaurant

3200 Devine's Sew Happy

3202 Wildflowers on Hawthorne

3204 Savy Plus

3206 What Goes Around?

3207 Perfect Fit Auto Upholstery

3208 In Her Image Gallery

3210 Murder by The Book

3239 Coit/Reese Cleaners

3240 Crone Magic (A)

3240 Hair Forte (B)

3267 Gearhart \& Gearhart

3267 Regco

3279 Graystone Gallery

3315 Bargain Boys

3315 Top Dog

3315 Rip City

3327 Hellums Mechanical Inc.

3328 Tamak Inc

3328 The Perfume House

3328 W Faulkner Collect

3335 Just Us Travel

3335 Margie Holmes

3335 Justice Co

3340 Vitna Print and Stationary

3341 Bead Needs

3343 Ancina Chiropractic Clinic

3344 Think Good Thoughts

3354 Hawthorne Street Cafe

1544 Arrow Typesetting

3401 Showcase Music \& Sound, Inc.

3415 Desitrek

3420 Arctic Circle

3433 Nibbles on Hawthorne

3435 Pricilla Ann's

3443 Northwest Futon Company

3445 Man's Best Friend

1430 Emert CPA

3500 City Glass
3508 World Neighbors

3518 Mark's Hawthorne Pub

3525 First Stop Video

3526 Artichoke Music

3530 Larry Milam Illustration

3530 Peter R. Diehl

3530 Second Story Books

3530 David Delamare Artwork

3534 Buttertoe's Cards and Gifts

3535 Madre Tierra

3537 Tara

3538 The Cat's Meow

3541 Visible Impact Resale Fashion

3545 Bowers Bakery and Deli

$3549 \mathrm{Fu}$ Jin Restaurant

3553 Macheesmo Mouse

3556 El Mundo, For Women

3557 Hawthorne Healthcare Center

3558 Illusionary Design

3558 Bauske \& Eller Attorneys

3562 The Hawthorne Coffee Merchant

3566 Cup and Saucer

3569 Hawthorne Health Center

3574 Backyard Birdhouses

3590 Ruby's Antiques and Gifts

1428 Hawthorne Stereo

3610 Bread \& Ink Cafe

3614 Linda Loving Florist

3621 Cutting Crew

3623 Crocodile Records

3628 Len's barber

3631 As If By Magic Gallery

3632 Tu-Be Tavern

3633 Presents of Mind

3635 Kids At Heart

3638 Escential

3639 Starbucks Coffee Co.

3646 Blue Butterfly

371416 Slater Construction

371420 D.Morrison Books

371429 Baba Roots

371431 Carolyn Locke

371435 Egads!

371512 37th Street Salon

371515 Echo Theatre

371520 Hostelling International

3701 Oasis Cafe

3702 Bagdad

3713 Sorel Vintages Ltd.

3720 Bagdad Pub

3723 Mar's Restaurant

3929 The Papermoon

3730 Hawthorne Florist

3731 Pastaworks

3734 Haggle Shop 
3736 Bird's Suite

3739 Powell's Books for Cooks

3739 Salumeria di Carlo

3742 Hawthorne Audio Exchange

3746 Nick's Coney Island

3747 Powell's on Hawthorne

3757 Bank of America

3760 Fred's Sound of Music

3766 Tabor Hill Cafe

3782 First Interstate

3805 Fred Meyer's

3832 Pacific First Bank

3862 Sunnyside Masonic Temple 